Prepared in cooperation with the National Park Service

\title{
Results of the Level-1 Water-Quality Inventory at the Pinnacles National Monument, June 2006
}

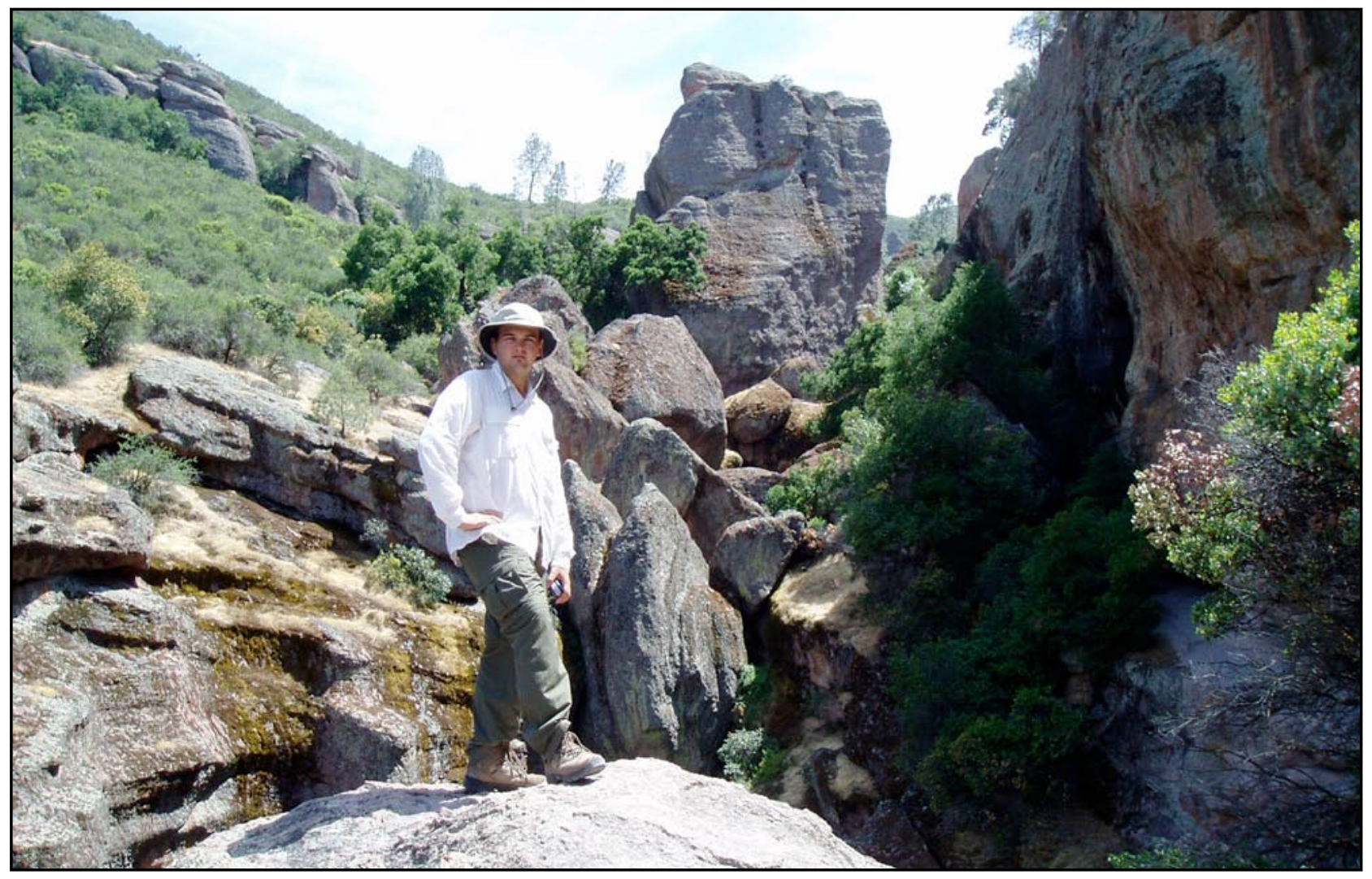

Data Series 283 
Michael Lyttge, USGS intern and Sacramento State Geology student, pauses on the Moses Spring trail, Pinnacles National Monument on June 6, 2006 , 


\section{Results of the Level-1 Water-Quality Inventory at the Pinnacles National Monument, June 2006}

By James W. Borchers and Michael S. Lyttge

Prepared in cooperation with the National Park Service

Data Series 283 


\section{U.S. Department of the Interior \\ Dirk Kempthorne, Secretary \\ U.S. Geological Survey \\ Mark D. Myers, Director}

\section{U.S. Geological Survey, Reston, Virginia: 2007}

For product and ordering information:

World Wide Web: http://www.usgs.gov/pubprod

Telephone: 1-888-ASK-USGS

For more information on the USGS--the Federal source for science about the Earth, its natural and living resources, natural hazards, and the environment:

World Wide Web: http://www.usgs.gov

Telephone: 1-888-ASK-USGS

Any use of trade, product, or firm names is for descriptive purposes only and does not imply endorsement by the U.S. Government.

Although this report is in the public domain, permission must be secured from the individual copyright owners to reproduce any copyrighted materials contained within this report.

Suggested citation:

Borchers, J.W., and Lyttge, M.S., 2007, Results of the Level-1 Water-Quality Inventory at the Pinnacles National Monument, June 2006: U.S. Geological Survey Data Series 283, 45 p. 


\section{Contents}

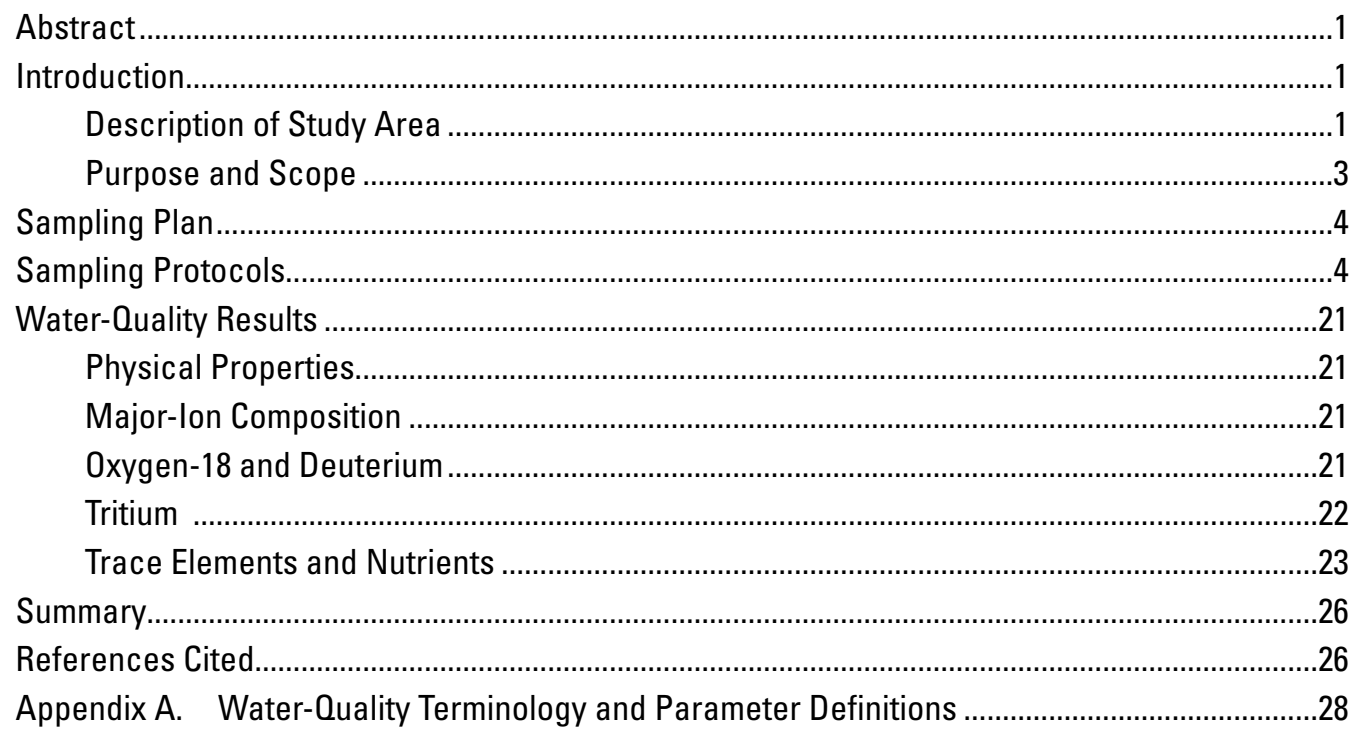

\section{Figures}

Figure 1. Map showing location of Pinnacles National Monument, California .............. 2

Figure 2. Map showing location of springs in Pinnacles National Monument sampled

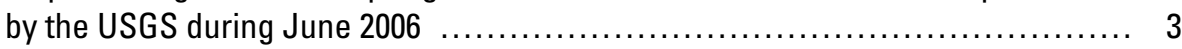

Figure 3. Photo showing Willow Spring sampling site at Willow Spring South Rivulet........ 10

Figure 4. Photo showing a chain-link enclosure sometimes used to trap feral pigs, adjacent to the sampling site at Willow Spring South Rivulet $\ldots \ldots \ldots \ldots \ldots \ldots \ldots 10$

Figure 5. Photo showing the concrete cistern at Oak Tree Spring opened for

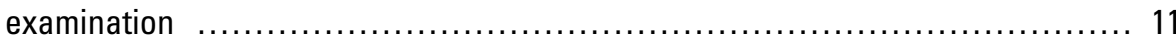

Figure 6. Photo showing the overflow pipe on the west side of the Oak Tree Spring cistern

Figure 7. Photo showing view upslope (to the east) toward McCabe Canyon

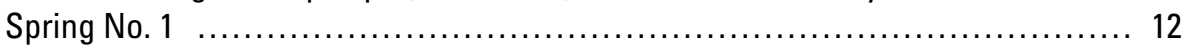

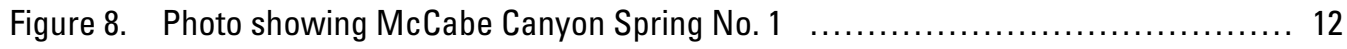

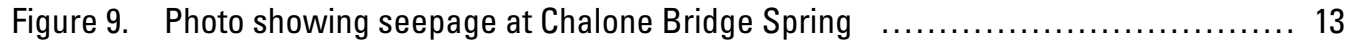

Figure 10. Photo showing an inscription on the downslope end of the concrete cistern at Chalone Bridge Spring indicating that the cistern was constructed by the Civilian

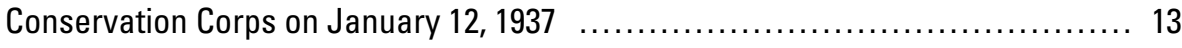

Figure 11. Photo showing seepage from Superintendent's Spring ........................ 14

Figure 12. Photo showing mossy "levees" adjacent to the spring outflow channel downslope from Superintendent's Spring 
Figure 13. Photo showing location of the subterranean concrete cistern at

Split Rock Spring

Figure 14. Photo showing inflow to the cistern at Split Rock Spring ....

Figure 15. Photo showing ground water discharging from Moses Spring .................. 16

Figure 16. Photo showing Moses Spring in a 1.5-foot-wide declivity in the rock wall adjacent to the Moses Spring Trail

Figure 17. Photo showing ground water issuing from Moses Spring at a hole in rhyolite breccia about 1.5 feet above the mossy spring pool

Figure 18. Diagram showing major-ion composition of samples from springs in Pinnacles National Monument in June 2006

Figure 19. Graph showing stable isotopic composition of samples from springs in Pinnacles National Monument in June 2006

Figure 20. Graph showing the concentrations of tritium in ground water sampled from springs in Pinnacles National Monument in June 2006 as triangles plotted at zero years, or present day at the time of this study, and the concentration range of tritium that remained in water that fell as precipitation in central coastal California when tritium concentrations in atmospheric water were at background levels

\section{Tables}

Table 1. Location and description of spring sampling sites in Pinnacles National

Monument, California, June 2006

Table 2. Physical property, major-ion, trace-element, and isotopic data for ground water sampled from springs at Pinnacles National Monument, California, June 2006

Table 3. Statistical summary of the concentration of major ions, trace elements, nutrients, and isotopes in spring samples, type of comparison threshold for drinking water and the corresponding threshold level, and threshold levels for freshwater aquatic life 


\section{Conversion Factors}

\section{Inch/Pound to SI}

\begin{tabular}{|c|c|c|}
\hline Multiply & By & To obtain \\
\hline \multicolumn{3}{|c|}{ Length } \\
\hline inch (in.) & 2.54 & centimeter $(\mathrm{cm})$ \\
\hline foot $(\mathrm{ft})$ & 0.3048 & meter $(\mathrm{m})$ \\
\hline mile (mi) & 1.609 & kilometer $(\mathrm{km})$ \\
\hline \multicolumn{3}{|c|}{ Area } \\
\hline acre & 4,047 & square meter $\left(\mathrm{m}^{2}\right)$ \\
\hline \multicolumn{3}{|c|}{ Volume } \\
\hline quart (qt) & 0.9464 & liter $(\mathrm{L})$ \\
\hline \multicolumn{3}{|c|}{ Flow rate } \\
\hline gallon per minute (gal/min) & 0.06309 & liter per second (L/s) \\
\hline \multicolumn{3}{|c|}{ Mass } \\
\hline pound, avoirdupois (lb) & 0.4536 & kilogram $(\mathrm{kg})$ \\
\hline \multicolumn{3}{|c|}{ Radioactivity } \\
\hline picocurie per liter (pCi/L) & 0.037 & becquerel per liter $(\mathrm{Bq} / \mathrm{L})$ \\
\hline
\end{tabular}

Temperature in degrees Celsius $\left({ }^{\circ} \mathrm{C}\right)$ may be converted to degrees Fahrenheit $\left({ }^{\circ} \mathrm{F}\right)$ as follows:

$$
{ }^{\circ} \mathrm{F}=\left(1.8 \times^{\circ} \mathrm{C}\right)+32
$$

Altitude, as used in this report, refers to distance above the National Geodetic Vertical Datum of 1929 (NGVD29).

Horizontal coordinate information is referenced to the North American Datum of 1983 (NAD83).

Specific conductance is given in microsiemens per centimeter at 25 degrees Celsius $(\mu \mathrm{S} / \mathrm{cm}$ at $\left.25^{\circ} \mathrm{C}\right)$.

Concentrations of chemical constituents in water are given either in milligrams per liter (mg/L) or micrograms per liter $(\mu \mathrm{g} / \mathrm{L})$.

\section{Abbreviations}

meq/L milliequivalents per liter

per mil parts per thousand 
This page intentionally left blank. 


\title{
Results of the Level-1 Water-Quality Inventory at the Pinnacles National Monument, June 2006
}

\author{
By James W. Borchers and Michael S. Lyttge
}

\section{Abstract}

To help define baseline water quality of key water resources at Pinnacles National Monument, California, the U.S. Geological Survey collected and analyzed ground water from seven springs sampled during June 2006. During the dry season, seeps and springs are the primary source of water for wildlife in the monument and provide habitat for plants, amphibians, and aquatic life. Water samples were analyzed for dissolved concentrations of major ions, trace elements, nutrients, stable isotopes of hydrogen and oxygen, and tritium. In most cases, the concentrations of measured water-quality constituents in spring samples were lower than California threshold standards for drinking water and Federal threshold standards for drinking water and aquatic life. The concentrations of dissolved arsenic in three springs were above the Federal Maximum Contaminant Level for drinking water (10 $\mu \mathrm{g} / \mathrm{L})$. Water-quality information for samples collected from the springs will provide a reference point for comparison of samples collected from future monitoring networks and hydrologic studies in the Pinnacles National Monument, and will help National Park Service managers assess relations between water chemistry, geology, and land use.

\section{Introduction}

In 1992, the National Park Service established, through its Inventory and Monitoring Program, a nationwide Level-1 Water-Quality Inventory process to obtain baseline waterquality information on key water bodies, to identify possible water-quality issues in national parks and monuments through the United States. Key water bodies are identified as those that are essential to the cultural, historical, or natural resourcemanagement themes, or that provide habitats for threatened or endangered plants and animals. During June 2006, the U.S. Geological Survey (USGS) collected water samples from seven springs in the Pinnacles National Monument in support of the Level-1 Water-Quality Inventory program of the National Park Service (NPS). These samples were analyzed to obtain water-quality information regarding key water resources at the Monument.

\section{Description of Study Area}

Pinnacles National Monument encompasses 24,265 acres in the Gabilan Range of San Benito and Monterey Counties, California (figs. 1 and 2). It is bordered by the San Andreas Fault on the northeast and the Salinas Valley to the southwest (fig. 1). Most of the monument is underlain by volcanic rocks - rhyolite flows, breccias, and tuffs that have been moved about 195 mi northwest along the San Andreas Fault from the western Mojave Desert. These rocks have been fractured, faulted, and deeply incised by streams, producing valleys and ridges of high topographic relief. Rocky ridges are typically more than $1,000 \mathrm{ft}$ above adjacent stream valleys. Parts of the Monument northeast from Chalone Creek are underlain by granitic fanglomerate-cemented sandy to bouldery sediments derived from a granitic source. Granitic rocks are exposed on the western and southeastern sides of the monument.

The area has a Mediterranean climate, with cold wet winters and hot dry summers. Average precipitation during 1948-2005 was 16.6 in. (http://www.wrcc.dri.edu/cgi-bin/cliMAIN.pl?capinn+sca, accessed September 12, 2005). Many streams in the monument are intermittent (drying up during the summer or fall) or ephemeral (flowing during and shortly after storms). Except for water from Bear Gulch Reservoir (fig. 2), and a few stock ponds, surface water is scarce; most of the monument's water resources are ground water (Mary Cooprider, National Park Service, written commun., 2005). During the dry season, the source of streamflow in perennial stream reaches is ground water that is discharged to stream channels diffusely through channel boundaries, or through seeps and springs that flow into the channels. During the dry season, ground-water discharge is a primary source of water for wildlife in the Monument and provides habitat for plants, amphibians, and aquatic life. 


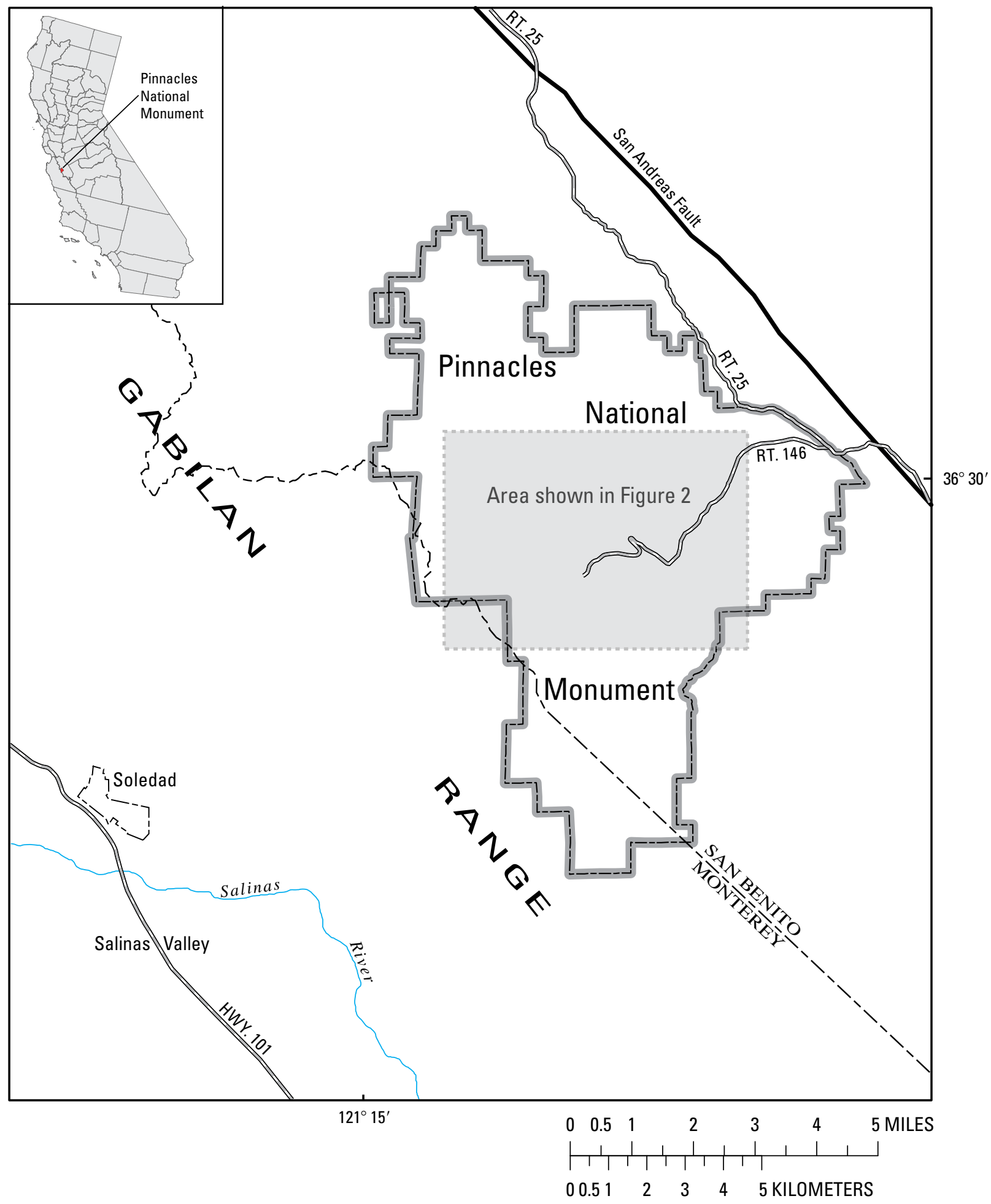

Figure 1. Location of Pinnacles National Monument, California. 


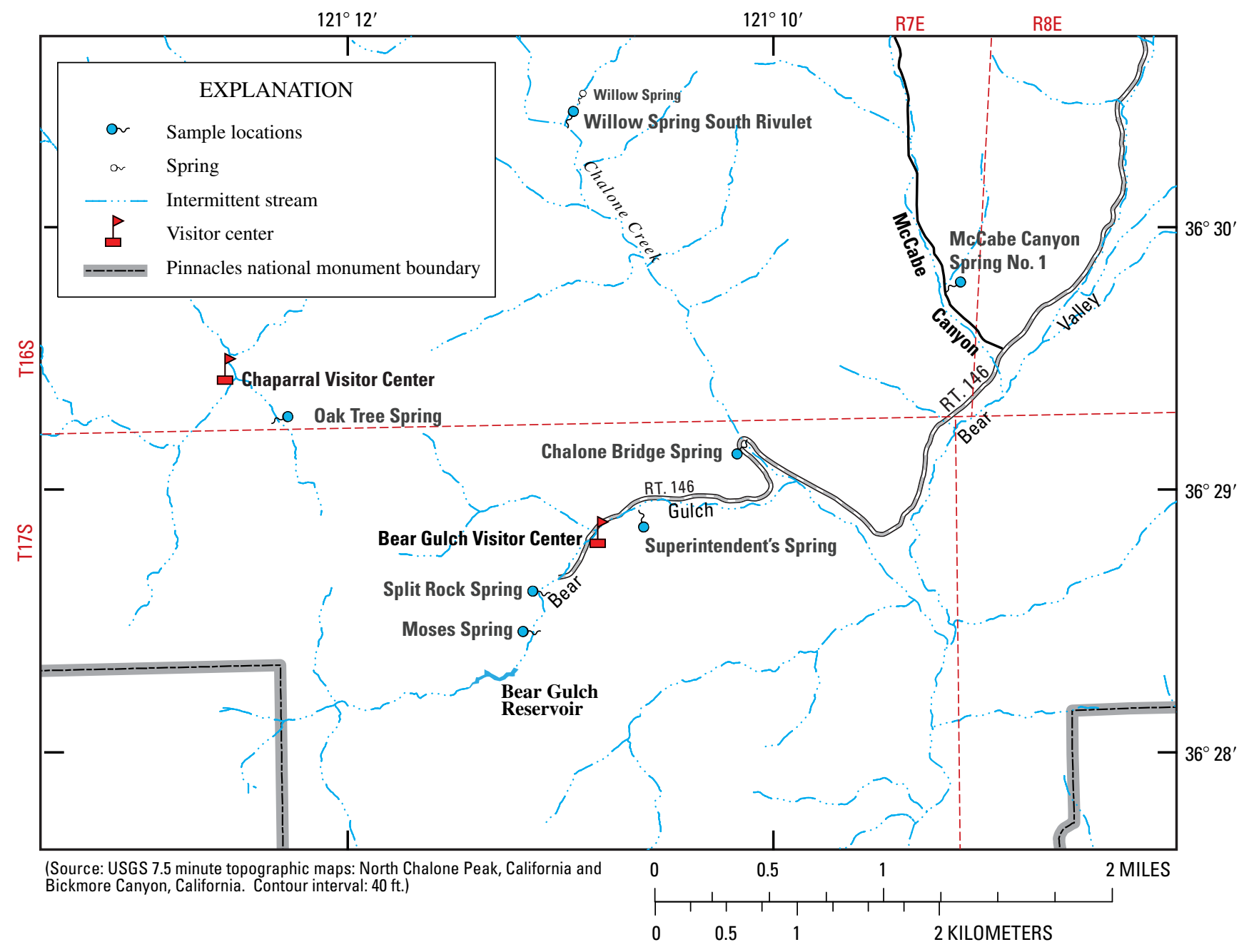

Figure 2. Location of springs in Pinnacles National Monument sampled by the USGS during June 2006.

\section{Purpose and Scope}

This data report summarizes the objectives, sampling plan, and sampling and analysis protocols used by the U.S. Geological Survey in conducting the level-1 baseline waterquality inventory of springs at Pinnacles National Monument. The objective of the report is to present water-quality information describing the general chemistry and isotopic composition of key water resources at the monument. The level-1 baseline water-quality inventory described in this data report focuses on perennial springs. NPS and USGS staff determined that waterquality samples should be collected from these springs and analyzed to determine the concentration of dissolved major ions, trace elements, nutrients, stable isotopes, and tritium. The National Park Service can use information in this data report to assess the current water quality of key springs and as a reference point for comparison of samples collected from future monitoring networks and hydrologic studies. The NPS can use the tritium and stable-isotope data in this report to derive some information on the recharge dates and evaporative history, respectively, of ground water in the monument. Establishing baseline water quality, ground-water age, and evaporative history of water from the springs provides information that will facilitate future study of ground-waterflow systems, stream-aquifer interaction, and wetlands. Ultimately, these data and future studies will improve the understanding of ground-water-flow systems that must be considered during the resource management decision-making process by NPS staff at Pinnacles National Monument.

The water quality of springs in the monument described in this report also is important from a critical habitat perspective. The California red-legged frog, listed as a threatened amphibian species by the Federal Government in 1996 (U.S. Fish and Wildlife Service, 2006), inhabits streams in Pinnacles National Monument. This amphibian species inhabits intermittent and perennial stream reaches (T. Leatherman, National Park Service, oral commun., 2005). The Pinnacles riffle beetle is found only in Pinnacles National Monument and surrounding area, and is ranked as an extremely endangered California endemic species in the California Natural Diversity Database. 
Additionally, Chalone Creek is habitat for an annelid worm that has not been identified elsewhere (S. Fend, USGS, oral commun., 2007). The sensitivity of the amphibian, beetle, and worm species to water availability, and possibly to water chemistry, requires that the Monument establish the baseline water quality of springs that are a primary source of stream water. This report provides that baseline information.

\section{Sampling Plan}

Historical information collected by the NPS helped identify candidate springs for sampling. NPS staff inventoried the location of 16 springs and seeps in 1997. In 2000, NPS staff surveyed the location of these 16 springs using Global Positioning System (GPS) receivers and determined the locations of an additional 23 possible seeps or springs from satellite infrared imagery or recollection of park staff. To help establish a ranking of key water resources at the monument springs that were visited by NPS staff during the GPS survey were described as either perennial or intermittent. Springs that are considered key resources by the NPS are those that provide flow to streams throughout the year, or those that provide enough flow to sustain aquatic habitat in parts of intermittent stream channels. The Level-1 Baseline Water-Quality Inventory described in this data report focuses on these key springs.

Using historical water-quality, streamflow, and NPS spring survey data, Geographic Information System (GIS) information provided by NPS staff (Mary Cooprider and Jason Herynk), topographic maps, and information provided by local residents, the USGS identified candidate springs for sampling. Candidate springs included perennial springs and springs of unknown flow constancy identified by NPS staff, and other springs identified on USGS topographic maps or suggested by local residents. Springs on privately owned land in the headwaters of Bear Gulch upstream from Bear Gulch Reservoir were not sampled because permission to access the springs was not obtained. As a result of consultation and field reconnaissance with NPS natural resources (Denise Louie, Paul Johnson), maintenance (John Osborne), and trail crew (Lisa Smith) staff during early June 2006, the USGS narrowed the list of candidate springs to seven. Spring sampling sites shown on figure 2 are described in table 1 . Photographs of each site are shown in figures 3-17.

During June 2006, USGS staff, assisted by NPS staff, sampled and measured field water-quality parameters (dissolved oxygen, $\mathrm{pH}$, specific conductance, temperature, and alkalinity) for seven springs characterized by NPS staff as likely to flow perennially. The source of flow from Willow Spring could not be determined precisely, owing to mass wasting, fallen timber, and heavily overgrown terrain in the small canyon containing the spring. A sample collected from Willow Spring South Rivulet, downstream from the mapped location of Willow Spring, is believed to be representative of ground water discharging from Willow Spring. Samples from other springs were collected from or close to the spring pool or cistern. All samples were analyzed for dissolved concentrations of major ions, trace elements, stable isotopes of hydrogen and oxygen, and for tritium. The constituents and analytical results are listed in table 2.

\section{Sampling Protocols}

Springs were sampled using equipment that had been cleaned with detergent and rinsed as described in the National Field Manual for the Collection of Water-Quality Data (U.S. Geological Survey, 1998), sealed in plastic bags, and packed in backpacks for transport, on foot, to the sampling sites. Water-quality samples were withdrawn from spring pools or from inflows or outflows of spring pools, using 140-mL plastic syringes. Samples were processed on site. Samples requiring filtration were passed from the syringe through a disposable disk or capsule filter $(0.45-\mu \mathrm{m}$ pore diameter) and into the appropriate sample bottle. Disk and capsule filters were rinsed with sample water before sample collection. Bottled samples for major-ion, trace-element, stable-isotope, and tritium analyses were sealed in a plastic bag and stored in a backpack for transport to an ice-filled cooler in a field vehicle at the trailhead. Samples for nutrient analysis and alkalinity titration were stored on ice in an insulated container and transported by backpack to an ice-filled cooler in a vehicle at the trailhead. Alkalinity samples were titrated within 5 or 6 hours of sample collection. Additional information about sample processing can be found in Appendix A.

Field measurements taken on-site included: dissolved oxygen, $\mathrm{pH}$, specific conductance, and air and water temperature. Except for dissolved oxygen, these parameters were measured using meters and by methods outlined by the USGS (1998). Dissolved oxygen was measured using a CHEMetrics colorimetric test kit (Gilbert and others, 1982).

The flow rate of water discharging from springs was either estimated visually or measured using the volumetric method described by Rantz and others (1982). Spring discharge was estimated visually at Willow Spring South Rivulet, Superintendent's Spring, Chalone Bridge Spring, and McCabe Canyon Spring No. 1. Discharge was measured volumetrically with a 5-qt container and stop watch at Split Rock Spring and Moses Spring, and with a 1-qt container and stop watch at Oak Tree Spring. 
Table 1. Location and description of spring sampling sites in Pinnacles National Monument, California, June 2006.

[CA, California; CCC, Civilian Conservation Corps; GPS, Global Positioning System; NGVD, National Geodetic Vertical Datum; NAD, North American Datum; Rt, Route; USGS, U.S. Geological Survey; mi, mile; ft, foot; in., inch]

\begin{tabular}{|c|c|c|c|c|c|}
\hline Local name & Station name & USGS Site ID & $\begin{array}{l}\text { Site } \\
\text { type }\end{array}$ & Access directions and site description & Purpose of monitoring \\
\hline
\end{tabular}

Oak Tree Spring
16S/7E-34NS1 $362920121122001 \quad$ Spring two rivulets, $250 \mathrm{ft}$ upstream from Chalone Creek, and approximately $100 \mathrm{ft}$ upstream from the North Wilderness Trail. The sample site is adjacent to a wild pig trap (chain link enclosure) about $0.1 \mathrm{mi}$ downstream from the location of Willow Spring (as shown on the USGS 7.5minute topographic quadrangle map, Bickmore Canyon, CA). This spring once served as a water supply for the old campground that was located at the present monument maintenance headquarters but is no longer used (figs. 3-4).

Oak Tree Spring is located in Juniper Canyon on the west side of the monument. Drive about 9 mi on Rt. 146 north and east from Metz-Soledad Road in the Salinas Valley. Walk southeast on the Juniper Canyon Trail from the trail head near the Chaparral Ranger Station. The spring is located about $1,600 \mathrm{ft}$ southeast from the trailhead and $155 \mathrm{ft}$ northwest from where the trail crosses the stream. An old concrete spring cistern (approximately $6 \mathrm{ft} \times 6 \mathrm{ft}$ $\times 4 \mathrm{ft}$ ) built by the CCC, is located in dense brush about $30 \mathrm{ft}$ east from the trail. When sampled, the spring cistern was filled with water and overflowed through a 1.25 -in pipe to the land surface (figs. 5-6).
This spring is identified on USGS topographic maps. National Park Service records indicate that Oak Tree Spring flows perennially. Discharge from Oak Tree Spring is low and infiltrates hillside colluvium downhill from the spring. The quality of water from this spring may be important because it is likely that the infiltrated water re-emerges and contributes to the base flow of the unnamed tributary (adjacent to Juniper Canyon Trail) that eventually joins Chalone Creek about $0.5 \mathrm{mi}$ west from Machete Ridge. 


\begin{tabular}{|c|c|c|c|c|}
\hline Local name & Station name & USGS Site ID & $\begin{array}{l}\text { Site } \\
\text { type }\end{array}$ & Access directions and site description \\
\hline $\begin{array}{l}\text { McCabe } \\
\text { Canyon } \\
\text { Spring } \\
\text { No. } 1\end{array}$ & 16S/7E-36HS1 & 362944121090801 & Spring & $\begin{array}{l}\text { McCabe Canyon Spring No. } 1 \text { is located in lower McCabe } \\
\text { Canyon on the east side of the monument. Drive about } \\
2 \text { mi south on Rt. } 146 \text { from Rt. } 25 \text { to a dirt road (Mc- } \\
\text { Cabe Canyon Road) on northwest side of Rt. } 146 \text { across } \\
\text { (northwest) from the National Park Service campground } \\
\text { near the monument entrance. Turn onto the dirt road, } \\
\text { which is gated and locked. The spring is located about } \\
200 \mathrm{ft} \text { east from-and about } 70 \mathrm{ft} \text { vertically higher } \\
\text { than-the road bed, approximately } 2,200 \mathrm{ft} \text { northwest on } \\
\text { McCabe Canyon Road from Rt. } 146 . \text { The spring issues } \\
\text { from granitic fanglomerate from which it has piped fine- } \\
\text { grained material and eroded about } 20 \mathrm{ft} \text { into the hillslope. } \\
\text { A marshy area just down slope (west) is fed by spring } \\
\text { discharge and by a nearby seep about } 20 \mathrm{ft} \text { north from the } \\
\text { rivulet discharging from the spring. According to a local } \\
\text { resident, wild pigs disturb marshy areas near seeps and } \\
\text { springs in McCabe Canyon (figs. } 7-8 \text { ). }\end{array}$ \\
\hline
\end{tabular}

Chalone

Bridge

Spring

$362912121101101 \quad \begin{aligned} & \text { Spring } \\ & \text { (seep) }\end{aligned}$

Chalone Bridge Spring issues from the west bank of Chalone Creek on the east side of the monument. Drive southwest on Rt. 146 past the east monument entrance and then northwest on Rt. 146. Turn left onto Bear Gulch Road; you will immediately cross Chalone Bridge. Park on road shoulder on the southwest side of the bridge. The spring is on the steep hillside, about $50 \mathrm{ft}$ south from the bridge and about $40 \mathrm{ft}$ west from the road. The hatch of a concrete cistern - of the same style and dimensions as the cistern at Oak Tree Spring-is sealed closed by the root of a live oak grown into the annulus between the hatch and the hatch opening. No discharge from the cistern was located during the USGS visit. Sample was collected from water seeping from colluvium on the top rear of the cistern (figs. 9-10).
Superinten-

dent's

Spring
17S/7E-2GS1 $362856121103801 \quad$ Spring

(seep)

\section{Superi}

Park Service sesing is located behind a National Park Service residence (formerly the Superintendent' residence), located on the east side of the monument, on the south side of Bear Gulch Road, approximately 0.2 mi northeast from the entrance to the Bear Gulch Visitor's Center. Climb about $250 \mathrm{ft}$ (horizontal distance) from the northeast corner of the house, up the steep north-facing hill slope. Climb just east from the residence avoiding the dense brush directly behind the house. Superintendent's Spring issues from an opening eroded in sandy colluvium and flows downslope in a 1-3-ft wide channel/trough bordered by unusual, moss-covered, woody levees. See figures 11 and 12 .
Purpose of monitoring

This is the most prominent spring in McCabe Canyon. It likely flows perennially. The quality of water from this spring is important because it contributes to the base flow of an unnamed tributary that joins Chalone Creek near the mouth of Bear Valley.

National Park Service records indicate that this spring may flow perennially. Discharge from Chalone Spring is extremely low where it was sampled, and infiltrates hillside colluvium downhill from the spring. The quality of water from this spring may be important if the infiltrated water re-emerges and provides base flow to Chalone Creek. Also, this sample may indicate the quality of ground water that discharges to Chalone Creek from other seeps and springs reported in the area.

National Park Service records indicate that this spring flows perennially. Discharge from Superintendent's Spring is low and infiltrates hillside colluvium downhill from the spring. The quality of water from this spring may be important if the infiltrated water re-emerges and provides base flow to Bear Creek. 
Table 1. Location and description of spring sampling sites in Pinnacles National Monument, California, June 2006-Continued.

[CA, California; CCC, Civilian Conservation Corps; GPS, Global Positioning System; NGVD, National Geodetic Vertical Datum; NAD, North American Datum; Rt, Route; USGS, U.S. Geological Survey; mi, mile; ft, foot; in., inch]

\begin{tabular}{|c|c|c|c|c|}
\hline Local name & Station name & USGS Site ID & $\begin{array}{l}\text { Site } \\
\text { type }\end{array}$ & Access directions and site description \\
\hline $\begin{array}{c}\text { Split Rock } \\
\text { Spring }\end{array}$ & 17S/7E-2MS1 & 362840121110801 & Spring & $\begin{array}{l}\text { Split Rock Spring is located in Bear Gulch on the east } \\
\text { side of the monument. Hike southwest from the Moses } \\
\text { Spring/High Peaks trailhead at the southwest end of Bear } \\
\text { Gulch Road. Approaching the split between Bear Gulch } \\
\text { and High Peaks Trail, look west across Bear Creek. } \\
\text { A pile of large boulders on the west bank of the creek } \\
\text { blocks the view of the } 20 \text {-ft square, } 8.2-\mathrm{ft} \text { high, concrete, } \\
\text { subterranean, spring cistern beneath a flat, grassy clear- } \\
\text { ing. To access the cistern, follow the High Peaks Trail for } \\
\text { about } 200 \mathrm{ft} \text { around a curve to the west. Proceed straight } \\
\text { north, off the trail, at the first switchback. Continue to } \\
\text { the flat grassy clearing and find the locked steel cistern } \\
\text { hatch under duff. Inflow to the cistern is from a 2-in } \\
\text { diameter pipe near the cistern ceiling on the south side } \\
\text { of the concrete cistern. Water flows from the cistern at } \\
\text { a sump at the base of the northern cistern wall. National } \\
\text { Park Service records indicate that cistern inflow is piped } \\
\text { from an upslope spring and french drain. The CCC built } \\
\text { the cistern in the 1930s to store water for NPS supply and } \\
\text { fire fighting (figs. 13-14). }\end{array}$ \\
\hline
\end{tabular}

Moses Spring 17S/7E-2NS1 $362830121111201 \quad$ Spring Moses Spring is located in Bear Gulch on the east side of the monument. Hike southwest from the Moses Spring/ High Peaks trailhead at the southwest end of Bear Gulch Road. At the split in the trail, follow sign and proceed on Bear Gulch Trail. The spring is on the west side of the trail about $0.4 \mathrm{mi}$ southwest from the Moses Spring/High Peaks trailhead. The small spring pool is hidden by ferns and other vegetation; it's outflow runs down the trail slope to the northeast. Ground water discharges from a 0.10 -in $\times 0.10$-in hole in rhyolite breccia that is $1.5 \mathrm{ft}$ vertically above a mossy pool. The spring was discovered in 1923, 12 years earlier than the construction of Bear Gulch Reservoir, which is located about 0.2 mi upstream from Moses Spring on Bear Creek (figs. 15-17).

Purpose of monitoring

National Park Service records indicate that Split Rock Spring may flow perennially. The quality of water from this spring is important because it likely contributes to the base flow of Bear Creek.

This spring is identified on USGS topographic maps. National Park Service records indicate that Moses Spring has flowed perennially over a long period of time. The quality of water from this spring is important because it likely contributes to the base flow of Bear Creek. 


\begin{tabular}{|c|c|c|c|c|c|c|c|c|c|}
\hline Local name & $\begin{array}{l}\text { Latitude/ } \\
\text { Longitude }\end{array}$ & $\begin{array}{c}\text { Latitude/ } \\
\text { Longitude } \\
\text { determination } \\
\text { method }\end{array}$ & $\begin{array}{l}\text { GPS } \\
\text { type }\end{array}$ & $\begin{array}{l}\text { Lat/long } \\
\text { reference } \\
\text { datum }\end{array}$ & $\begin{array}{l}\text { County, } \\
\text { State }\end{array}$ & $\begin{array}{c}\text { USGS } \\
\text { Hydrologic } \\
\text { Unit } \\
\text { Code } \\
\text { (HUC) } \\
\end{array}$ & $\begin{array}{c}\text { Elevation } \\
\text { (feet) }\end{array}$ & $\begin{array}{c}\text { Elevation } \\
\text { source }\end{array}$ & $\begin{array}{c}\text { Elevation } \\
\text { datum }\end{array}$ \\
\hline $\begin{array}{c}\text { Willow Spring } 36 \\
\text { South Rivulet }\end{array}$ & $\begin{array}{l}36^{\circ} 30^{\prime} 28^{\prime \prime} \\
121^{\circ} 10^{\prime} 58^{\prime \prime}\end{array}$ & Hand-held GPS uni & $\begin{array}{l}\text { Magellan } \\
\text { eXplorist } \\
200\end{array}$ & NAD 83 & $\begin{array}{l}\text { San Benito, } \\
\text { CA }\end{array}$ & 18060005 & $1,110 \pm 20$ & $\begin{array}{l}\text { USGS } \\
\text { Quadrangle } \\
\text { Map- } \\
\text { Bickmore } \\
\text { Canyon, } \\
\text { CA. 7.5- } \\
\text { minute } \\
\text { series }\end{array}$ & 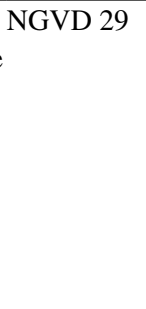 \\
\hline $\begin{array}{r}\text { Oak Tree } \\
\text { Spring }\end{array}$ & $\begin{array}{l}36^{\circ} 29^{\prime} 20^{\prime \prime} \\
121^{\circ} 12^{\prime} 20^{\prime \prime}\end{array}$ & Hand-held GPS uni & $\begin{array}{l}\text { Magellan } \\
\text { eXplorist } \\
200\end{array}$ & NAD 83 & $\begin{array}{l}\text { San Benito, } \\
\text { CA }\end{array}$ & 18060005 & $1,480 \pm 20$ & $\begin{array}{l}\text { USGS } \\
\text { Quadrangle } \\
\text { Map- } \\
\text { North } \\
\text { Chalone } \\
\text { Peak, CA. } \\
\text { 7.5-minute } \\
\text { series }\end{array}$ & NGVD 29 \\
\hline $\begin{array}{l}\text { McCabe } \\
\text { Canyon } \\
\text { Spring No. } 1\end{array}$ & $\begin{array}{l}36^{\circ} 29^{\prime} 44^{\prime \prime} \\
121^{\circ} 09^{\prime} 08^{\prime \prime}\end{array}$ & Hand-held GPS uni & $\begin{array}{l}\text { Magellan } \\
\text { eXplorist } \\
200\end{array}$ & NAD 83 & $\begin{array}{l}\text { San Benito, } \\
\text { CA }\end{array}$ & 18060005 & $1,150 \pm 20$ & $\begin{array}{l}\text { USGS } \\
\text { Quadrangle } \\
\text { Map- } \\
\text { North } \\
\text { Chalone } \\
\text { Peak, CA. } \\
\text { 7.5-minute } \\
\text { series }\end{array}$ & NGVD 29 \\
\hline
\end{tabular}


Table 1. Location and description of spring sampling sites in Pinnacles National Monument, California, June 2006 —Continued.

[CA, California; CCC, Civilian Conservation Corps; GPS, Global Positioning System; NGVD, National Geodetic Vertical Datum; NAD, North American Datum; Rt, Route; USGS, U.S. Geological Survey; mi, mile; ft, foot; in., inch]

\begin{tabular}{|c|c|c|c|c|c|c|c|c|c|}
\hline Local name & $\begin{array}{l}\text { Latitude/ } \\
\text { Longitude }\end{array}$ & $\begin{array}{c}\text { Latitude/ } \\
\text { Longitude } \\
\text { determination } \\
\text { method }\end{array}$ & $\begin{array}{l}\text { GPS } \\
\text { type }\end{array}$ & $\begin{array}{l}\text { Lat/long } \\
\text { reference } \\
\text { datum }\end{array}$ & $\begin{array}{l}\text { County, } \\
\text { State }\end{array}$ & $\begin{array}{c}\text { USGS } \\
\text { Hydrologic } \\
\text { Unit } \\
\text { Code } \\
\text { (HUC) }\end{array}$ & $\begin{array}{c}\text { Elevation } \\
\text { (feet) }\end{array}$ & $\begin{array}{c}\text { Elevation } \\
\text { source }\end{array}$ & $\begin{array}{c}\text { Elevation } \\
\text { datum }\end{array}$ \\
\hline $\begin{array}{l}\text { Superinten- } \\
\text { dent's Spring }\end{array}$ & $\begin{array}{l}36^{\circ} 28^{\prime} 56^{\prime \prime} \\
121^{\circ} 10^{\prime} 38^{\prime \prime}\end{array}$ & $\begin{array}{l}\text { Hand-held } \\
\text { GPS unit }\end{array}$ & $\begin{array}{l}\text { Magellan } \\
\text { eXplorist } \\
200\end{array}$ & NAD 83 & $\begin{array}{l}\text { San Benito, } \\
\text { CA }\end{array}$ & 18060005 & $1,390 \pm 40$ & $\begin{array}{l}\text { USGS } \\
\text { Quadrangle } \\
\text { Map- } \\
\text { North } \\
\text { Chalone } \\
\text { Peak, CA. } \\
\text { 7.5-minute } \\
\text { series }\end{array}$ & $\mathrm{e}^{\mathrm{NGVD} 29}$ \\
\hline $\begin{array}{l}\text { Split Rock } \\
\text { Spring }\end{array}$ & $\begin{array}{l}36^{\circ} 28^{\prime} 40^{\prime \prime} \\
121^{\circ} 11^{\prime} 08^{\prime \prime}\end{array}$ & $\begin{array}{l}\text { Hand-held } \\
\text { GPS unit }\end{array}$ & $\begin{array}{l}\text { Magellan } \\
\text { eXplorist } \\
200\end{array}$ & NAD 83 & $\begin{array}{l}\text { San Benito, } \\
\text { CA }\end{array}$ & 18060005 & $1,430 \pm 20$ & $\begin{array}{l}\text { USGS } \\
\text { Quadrangle } \\
\text { Map- } \\
\text { North } \\
\text { Chalone } \\
\text { Peak, CA. } \\
\text { 7.5-minute } \\
\text { series }\end{array}$ & $\mathrm{e}^{\text {NGVD } 29}$ \\
\hline Moses Spring & $\begin{array}{l}36^{\circ} 28^{\prime} 30^{\prime \prime} \\
121^{\circ} 11^{\prime} 12^{\prime \prime}\end{array}$ & $\begin{array}{l}\text { Hand-held } \\
\text { GPS unit }\end{array}$ & $\begin{array}{l}\text { Magellan } \\
\text { eXplorist } \\
200\end{array}$ & NAD 83 & $\begin{array}{l}\text { San Benito, } \\
\text { CA }\end{array}$ & 18060005 & $1,580 \pm 20$ & $\begin{array}{l}\text { USGS } \\
\text { Quadrangle } \\
\text { Map- } \\
\text { North } \\
\text { Chalone } \\
\text { Peak, CA. } \\
\text { 7.5-minute } \\
\text { series }\end{array}$ & $\mathrm{e}^{\text {NGVD } 29}$ \\
\hline
\end{tabular}




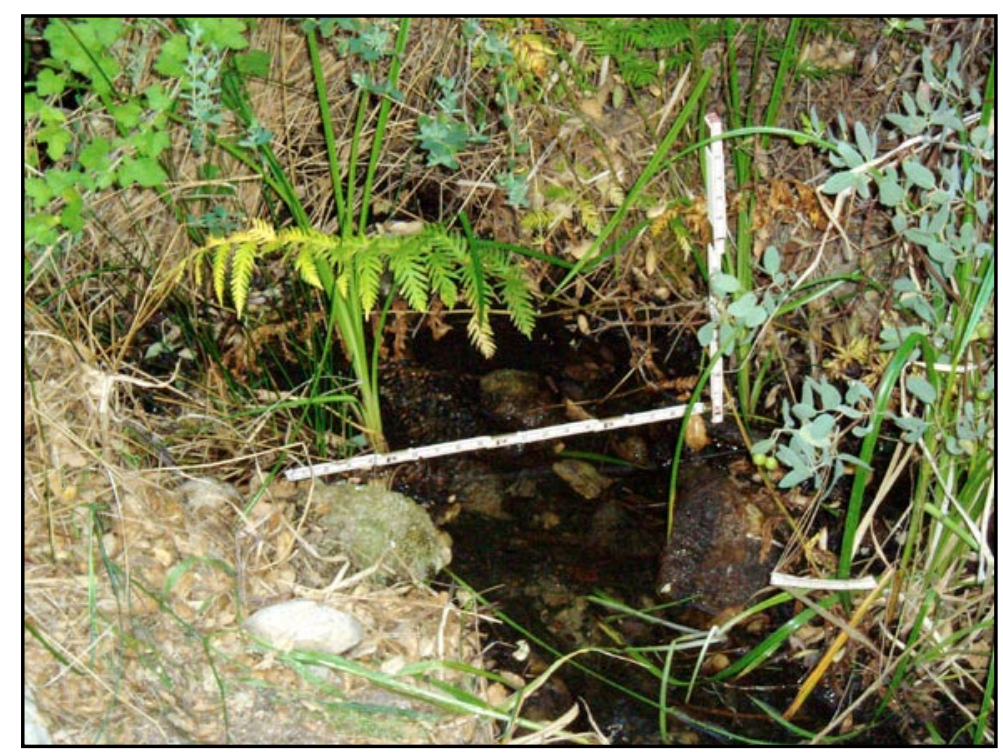

Figure 3. Willow Spring sampling site at Willow Spring South Rivulet.

(The folding scale is bent upward at 2 feet.)

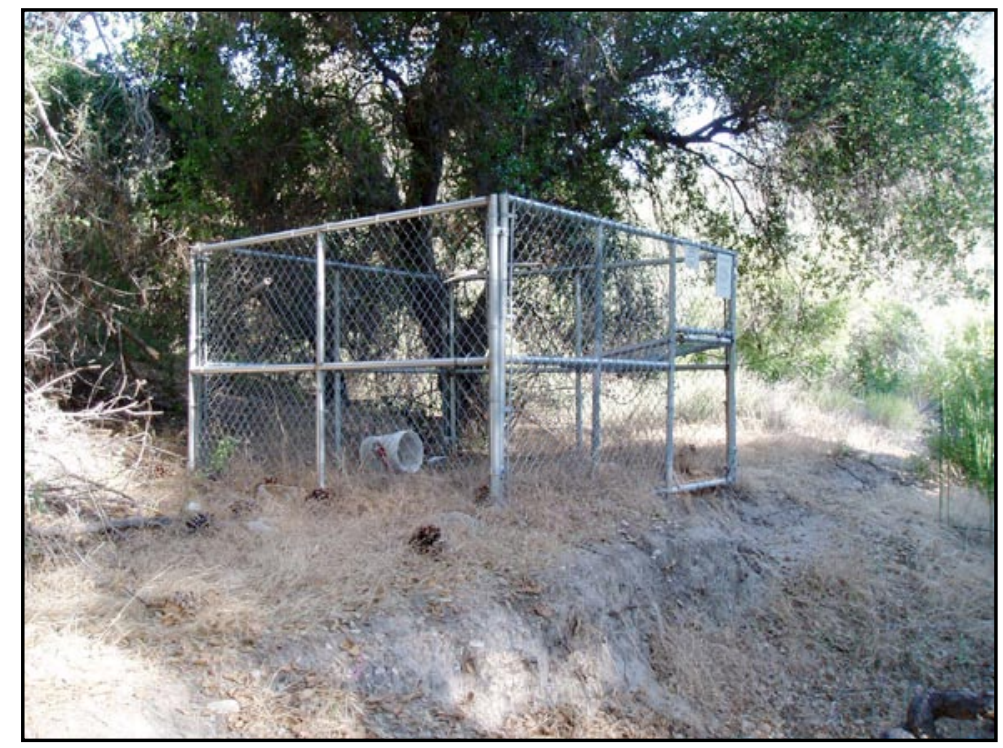

Figure 4. A chain-link enclosure sometimes used to trap feral pigs, adjacent to the sampling site at Willow Spring South Rivulet. 


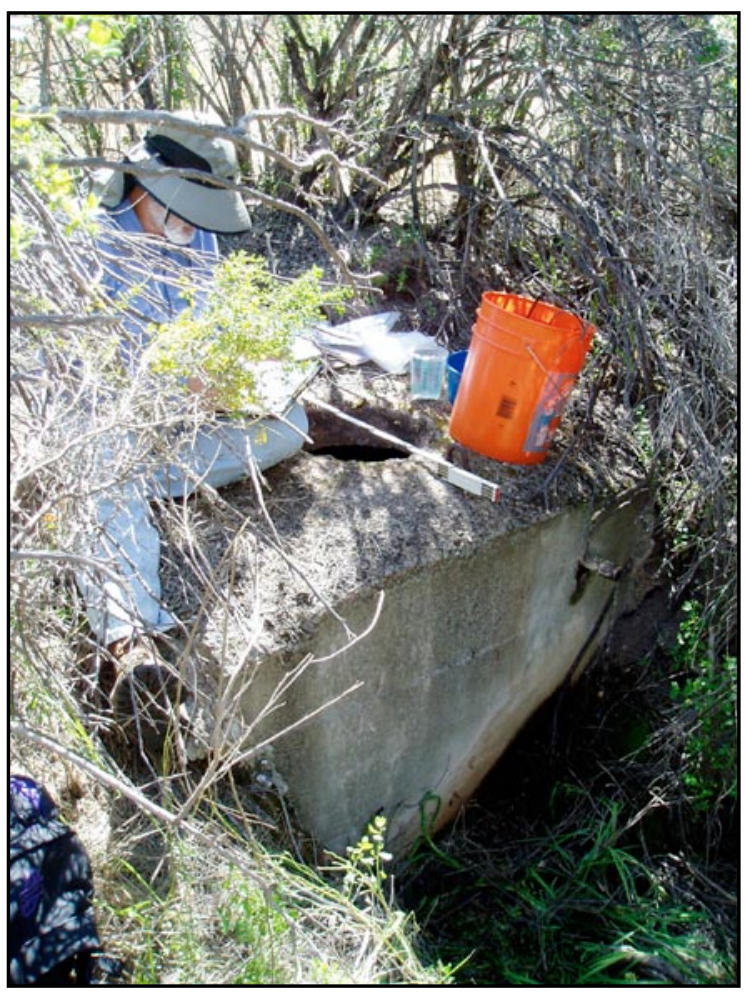

Figure 5. The concrete cistern at Oak Tree Spring opened for examination.

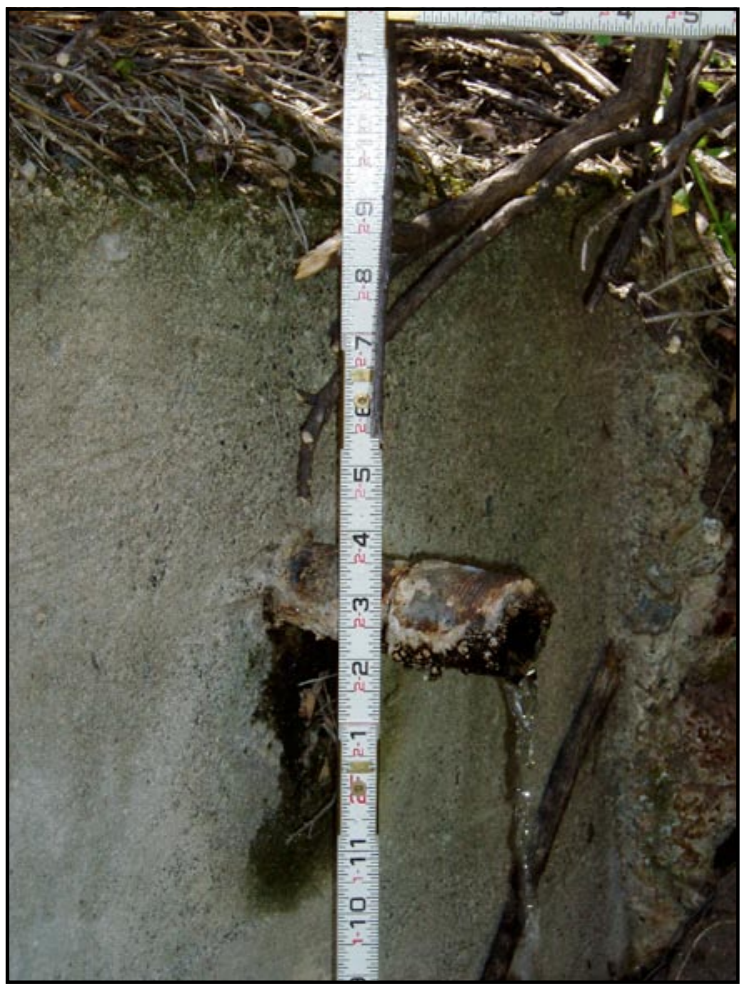

Figure 6. The overflow pipe on the west side of the 0ak Tree Spring cistern. 


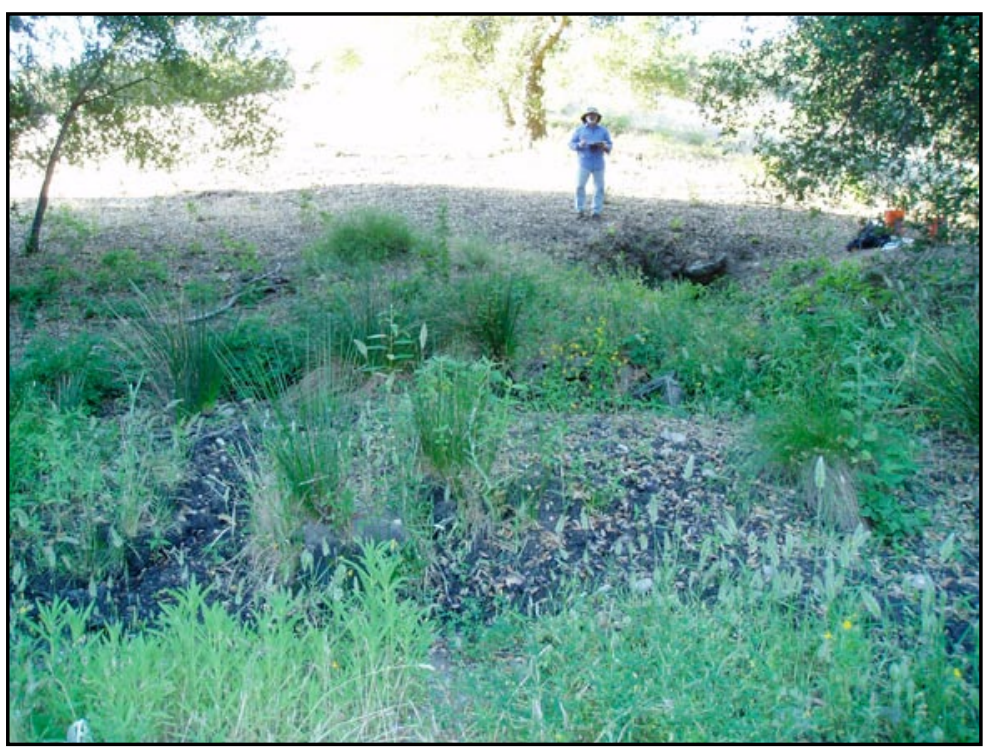

Figure 7. View upslope (to the east) toward McCabe Canyon Spring No. 1.

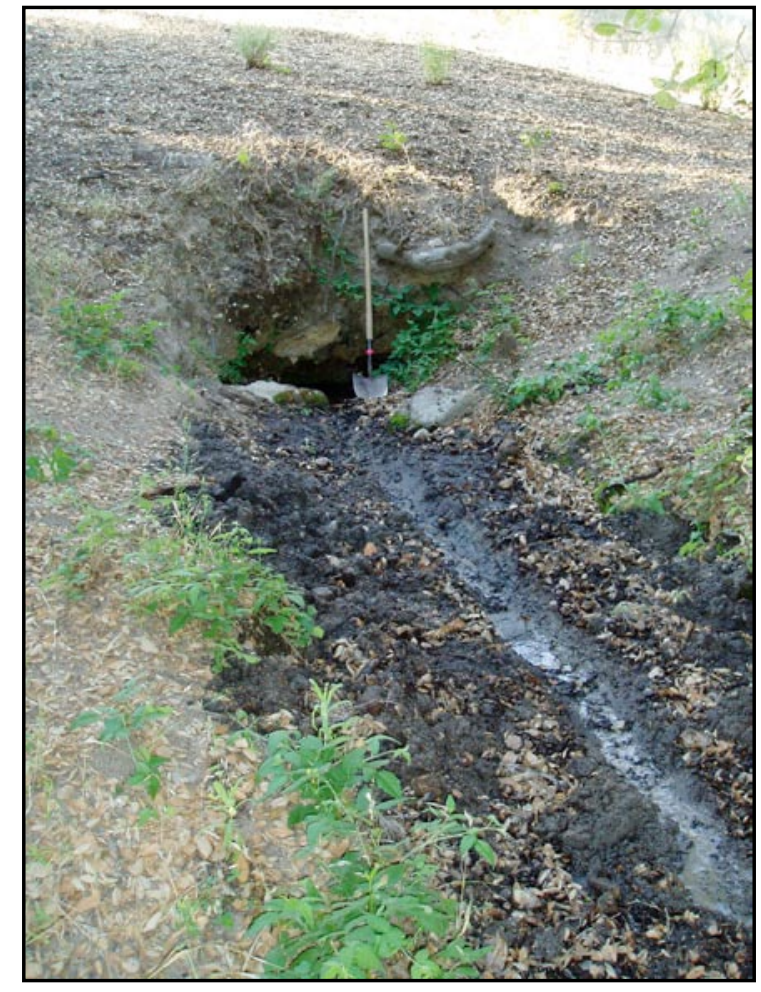

Figure 8. McCabe Canyon Spring No. 1. 


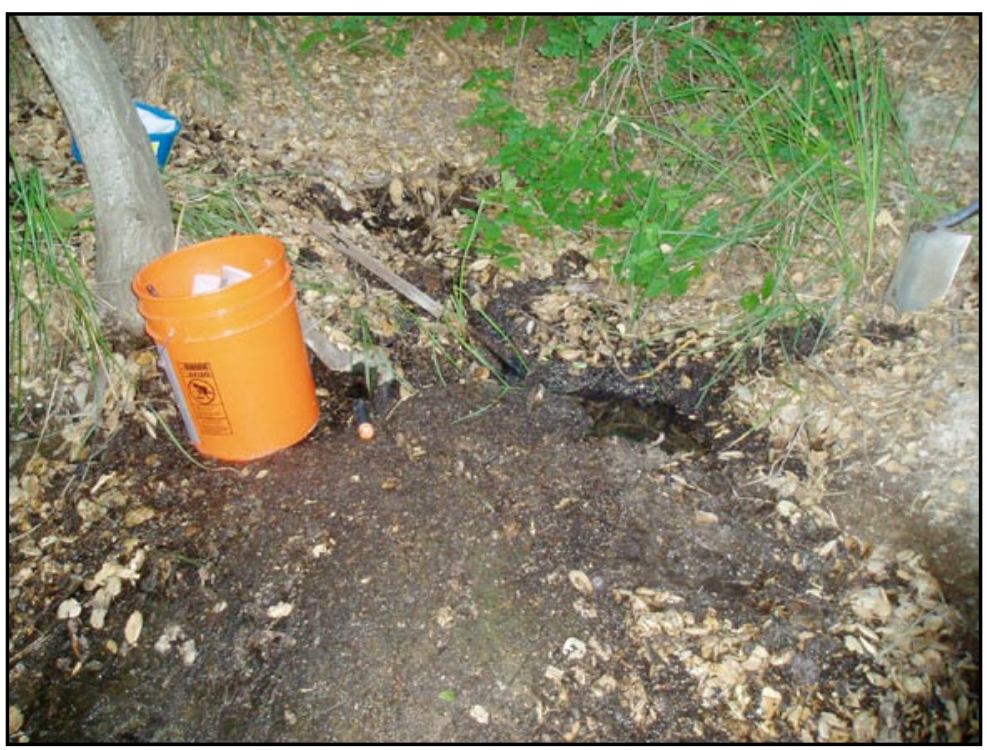

Figure 9. Seepage at Chalone Bridge Spring.

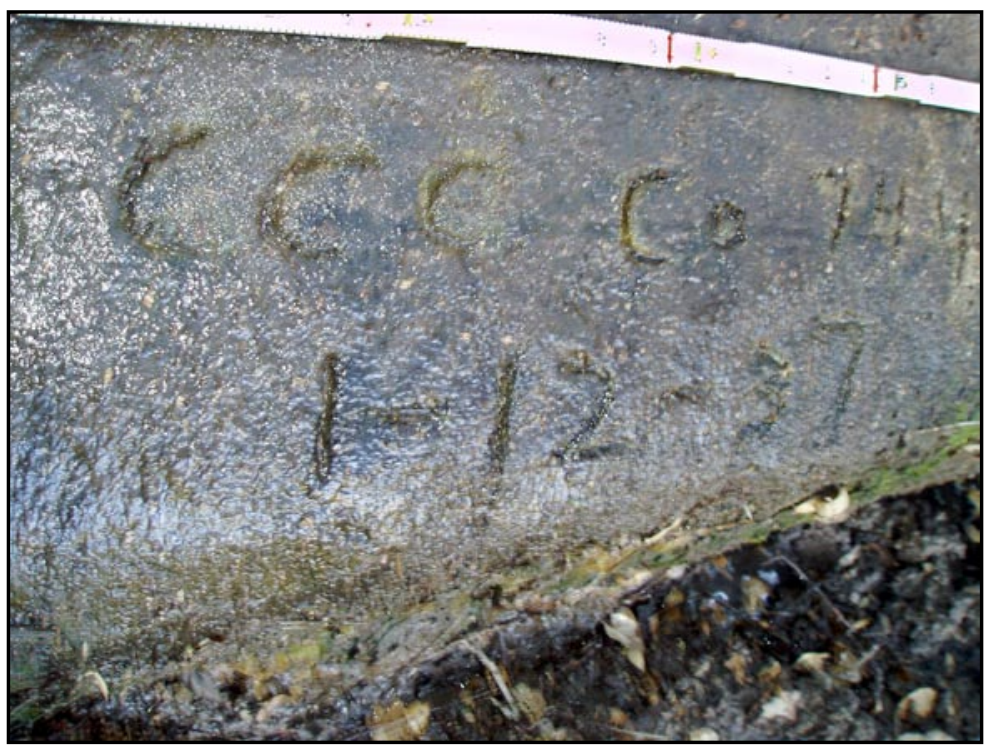

Figure 10. An inscription on the downslope end of the concrete cistern at Chalone Bridge Spring indicating that the cistern was constructed by the Civilian Conservation Corps on January 12, 1937. 


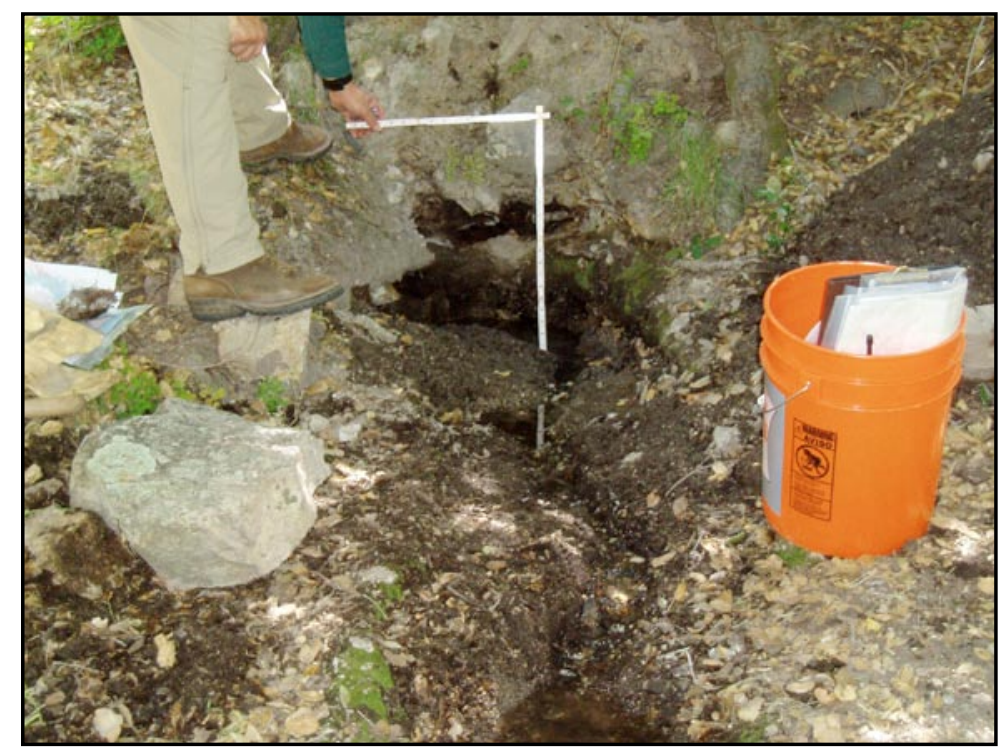

Figure 11. Seepage from Superintendent's Spring.

(The folding scale is bent to the side at 2 feet.)

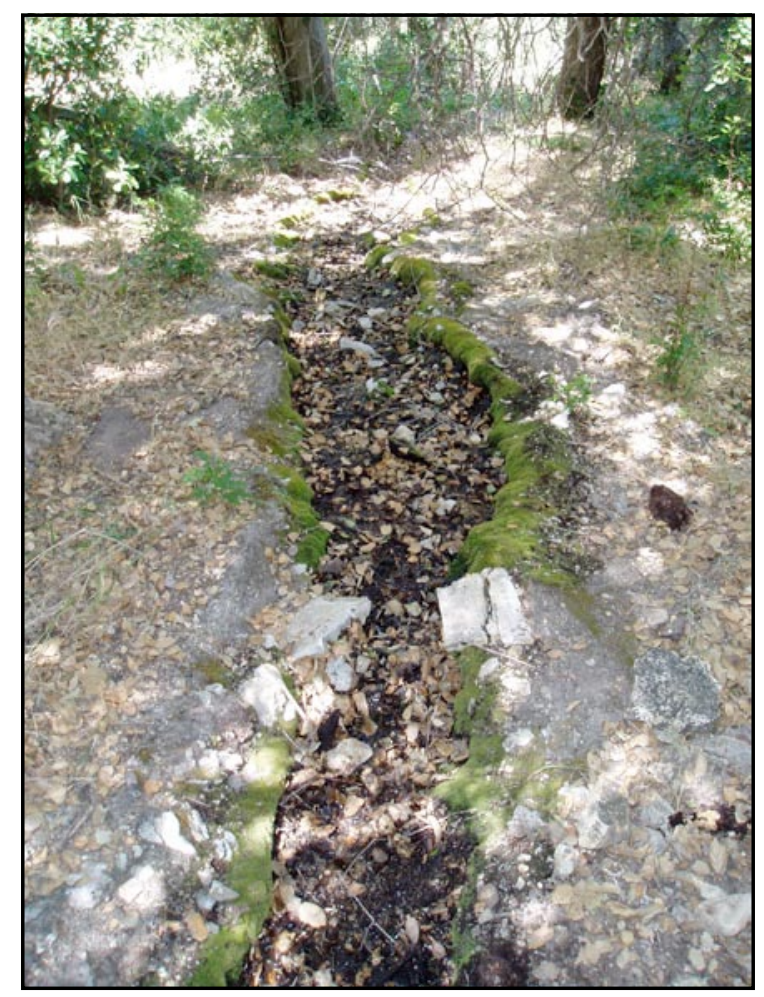

Figure 12. Mossy "levees" adjacent to the spring outflow channel downslope from Superintendent's Spring. 


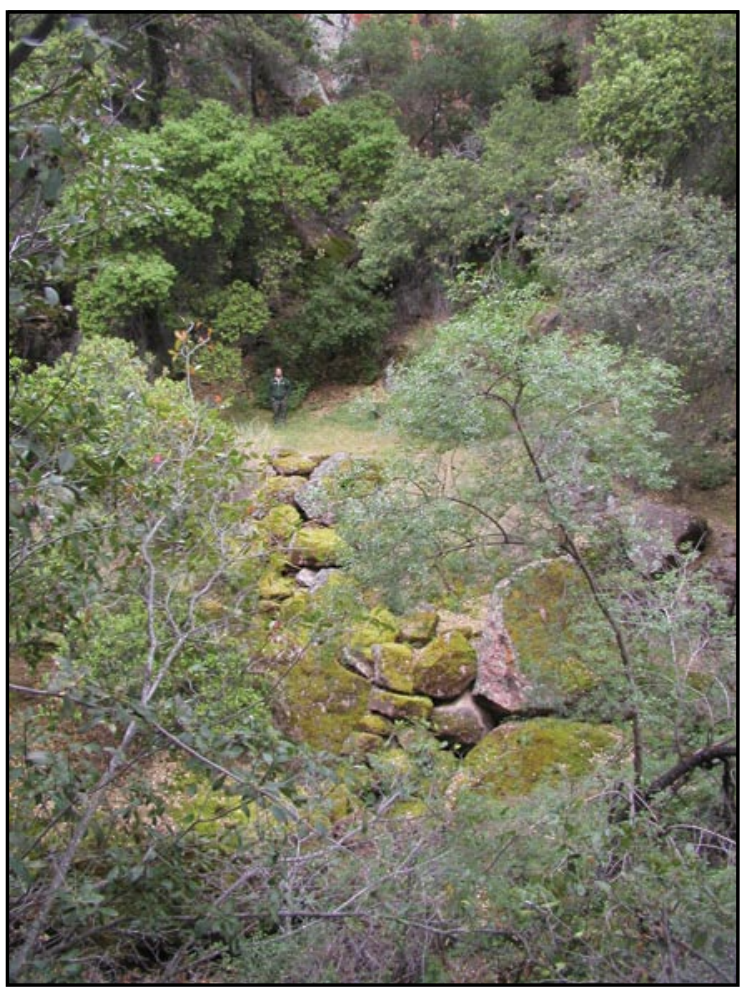

Figure 13. View to the west at the location of the subterranean concrete cistern at Split Rock Spring.

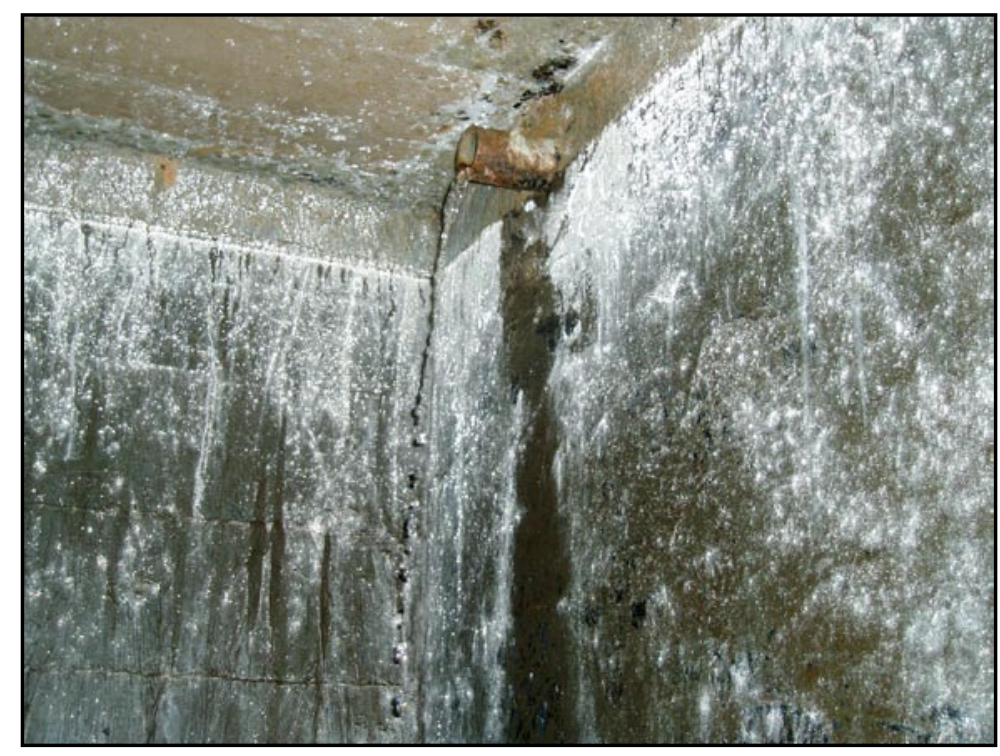

Figure 14. Inflow to the cistern at Split Rock Spring through 2-inch diameter steel pipe near the cistern ceiling. 


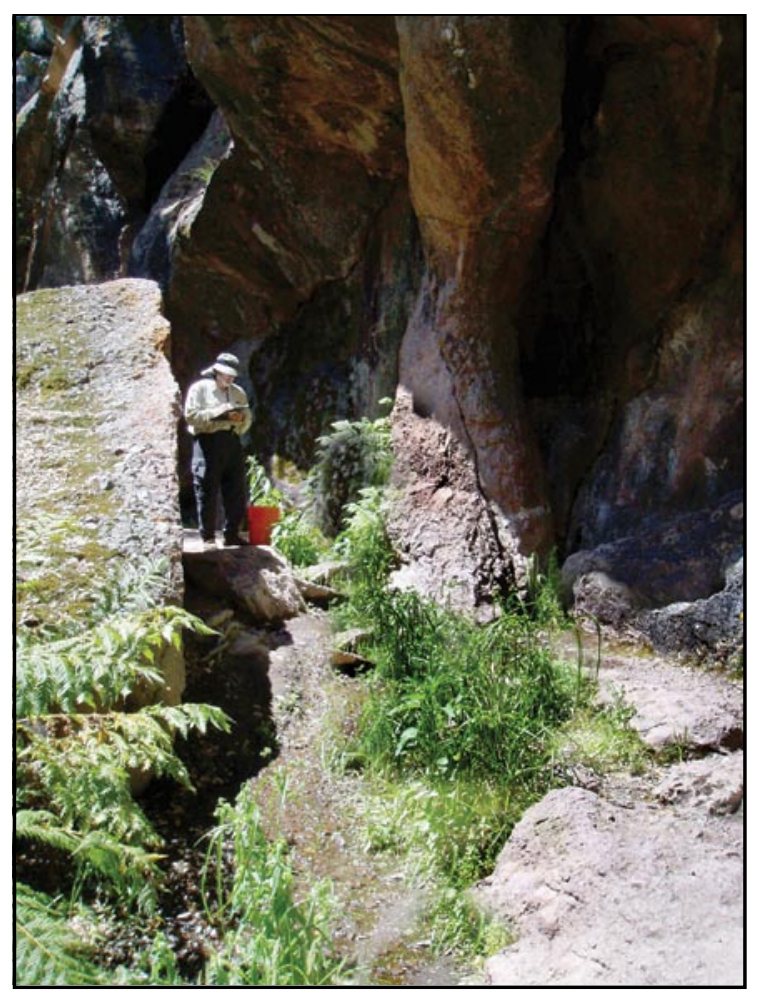

Figure 15. Ground water discharging from Moses Spring.

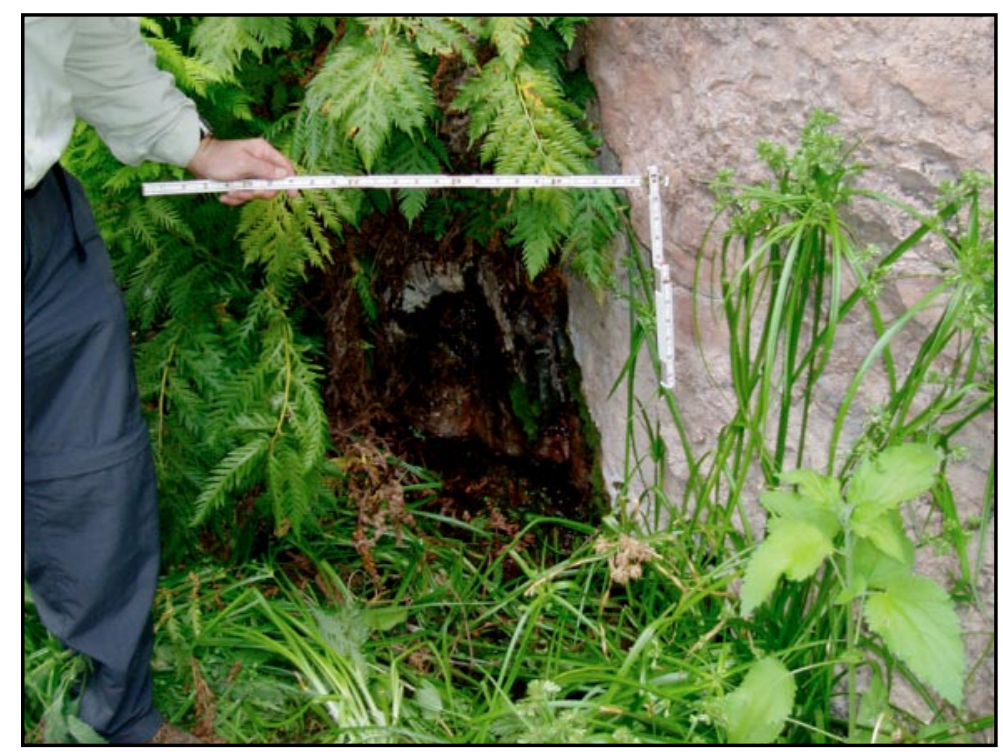

Figure 16. Moses Spring in a 1.5-foot-wide declivity in the rock wall adjacent to the Moses Spring Trail. (The folding scale is bent down at 2.5 feet.) 


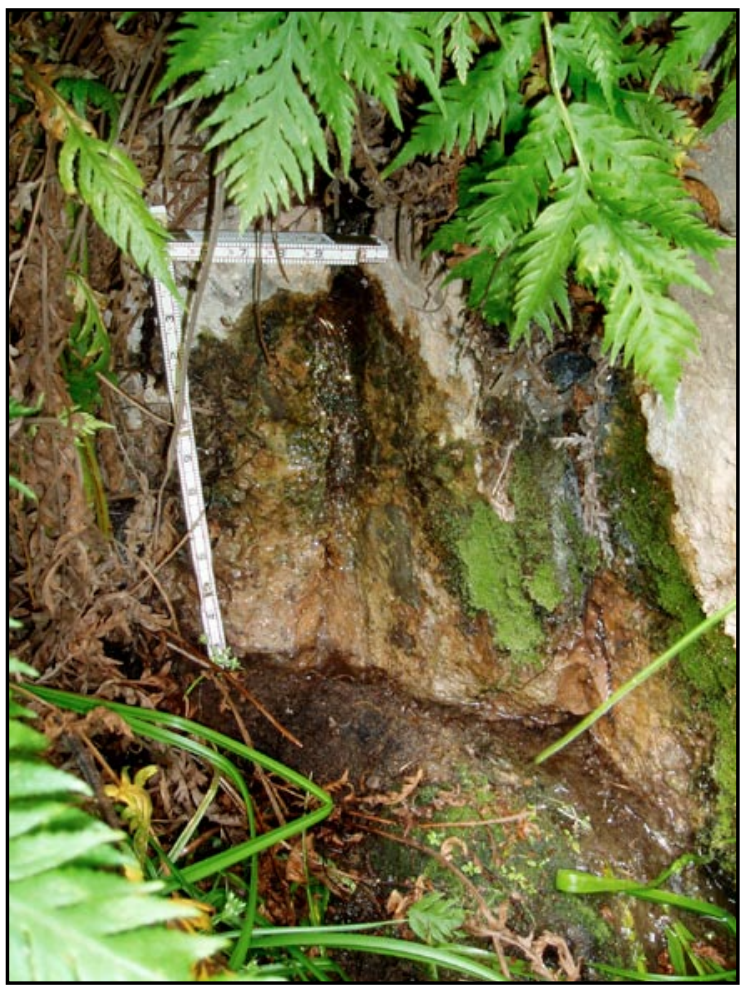

Figure 17. Ground water issuing from Moses Spring at a hole in rhyolite breccia about 1.5 feet above the mossy spring pool.

(The folding scale is bent to the side at 1.5 feet.)

Analyses of spring samples to determine the concentration of major ions, nutrients, and trace elements were conducted by the USGS National Water Quality Laboratory in Lakewood, Colorado. Analytical procedures used at the National Water Quality Laboratory are described by Faires (1993); Fishman and Friedman (1989); Fishman (1993); Garbarino, Kanagy, and Cree (2006); Garbarino (1999); Patton and Truitt (1992); and Patton and Krysyalla (2003). In addition, the National Water Quality Laboratory followed laboratory quality-assurance protocols detailed in Maloney (2005). The stable-isotope composition (oxygen-18 and deuterium) of spring samples was determined at the USGS Isotope Lab in Reston, Virginia. The procedural methods for the isotopic analyses are described by Coplen and others (1991) and Epstein and Mayeda (1953). Measurements of tritium concentration of spring samples were conducted at the University of Miami Tritium Laboratory in Miami, Florida. A description of the methods used is described by Östlund (1987).
For quality-assurance purposes, temperature meters were calibrated in USGS labs in Sacramento, California, prior to field sampling. The $\mathrm{pH}$ and specific-conductance meters were calibrated in the field twice daily with known standards. Sampling equipment was cleaned before the collection of each sample. To evaluate the potential for cross-contamination during field sampling, a field blank was collected and processed at Moses Spring at the beginning of the sampling effort on June 6, 2006. A field blank is an aliquot of inorganic-free blank water, purchased from a commercial laboratory and processed identically to environmental samples - passed through the $140-\mathrm{mL}$ sampling syringe and $0.45-\mu \mathrm{m}$ disk filter and into a sample bottle. The field blank was analyzed for trace elements, nutrients, and total nitrogen. The field blank was not analyzed for major ions because the specific conductance was sufficiently low $(1 \mu \mathrm{S} / \mathrm{cm})$ to ensure that the concentrations of dissolved major ions were not present at levels within an order of magnitude of concentrations in the environmental samples. 
范

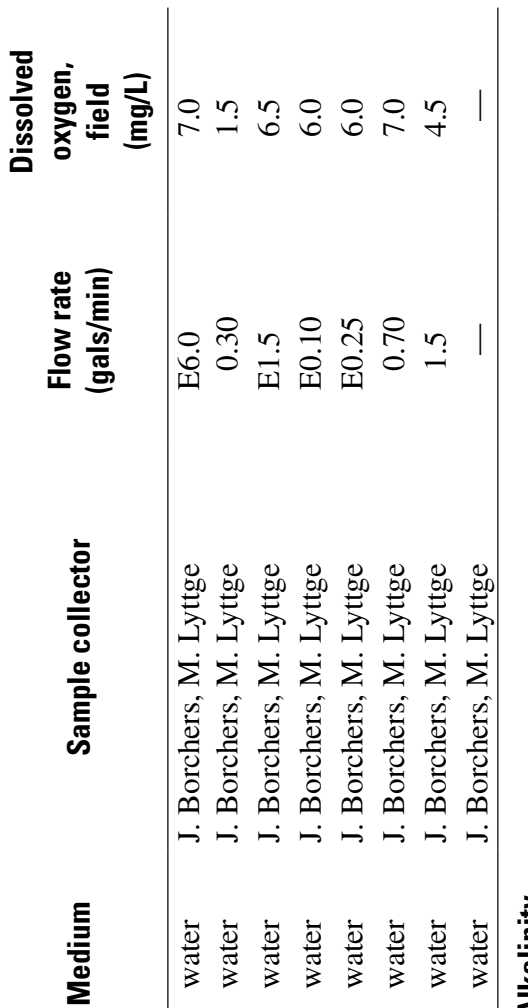

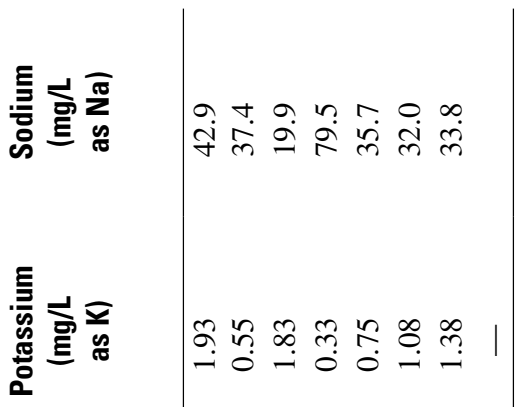

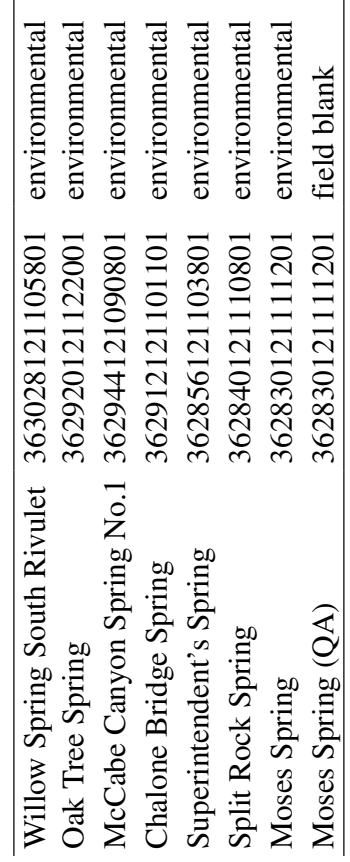

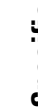

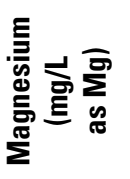

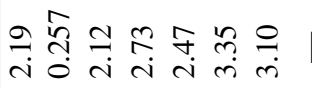

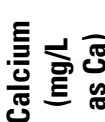

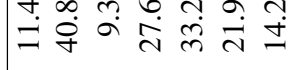

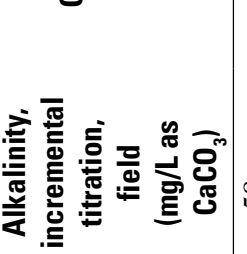

们寻。正命

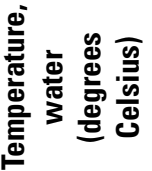

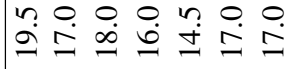

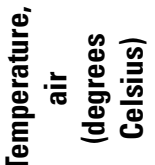

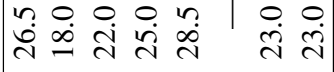

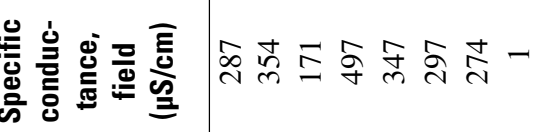

营

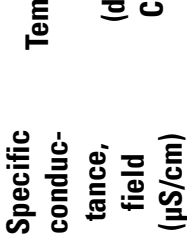

돌 증

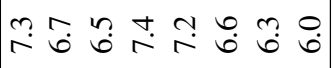

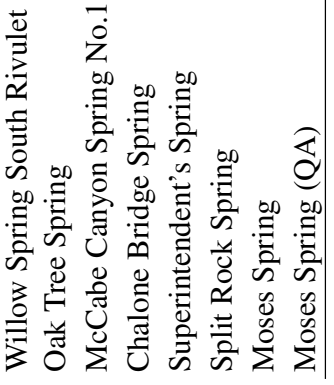









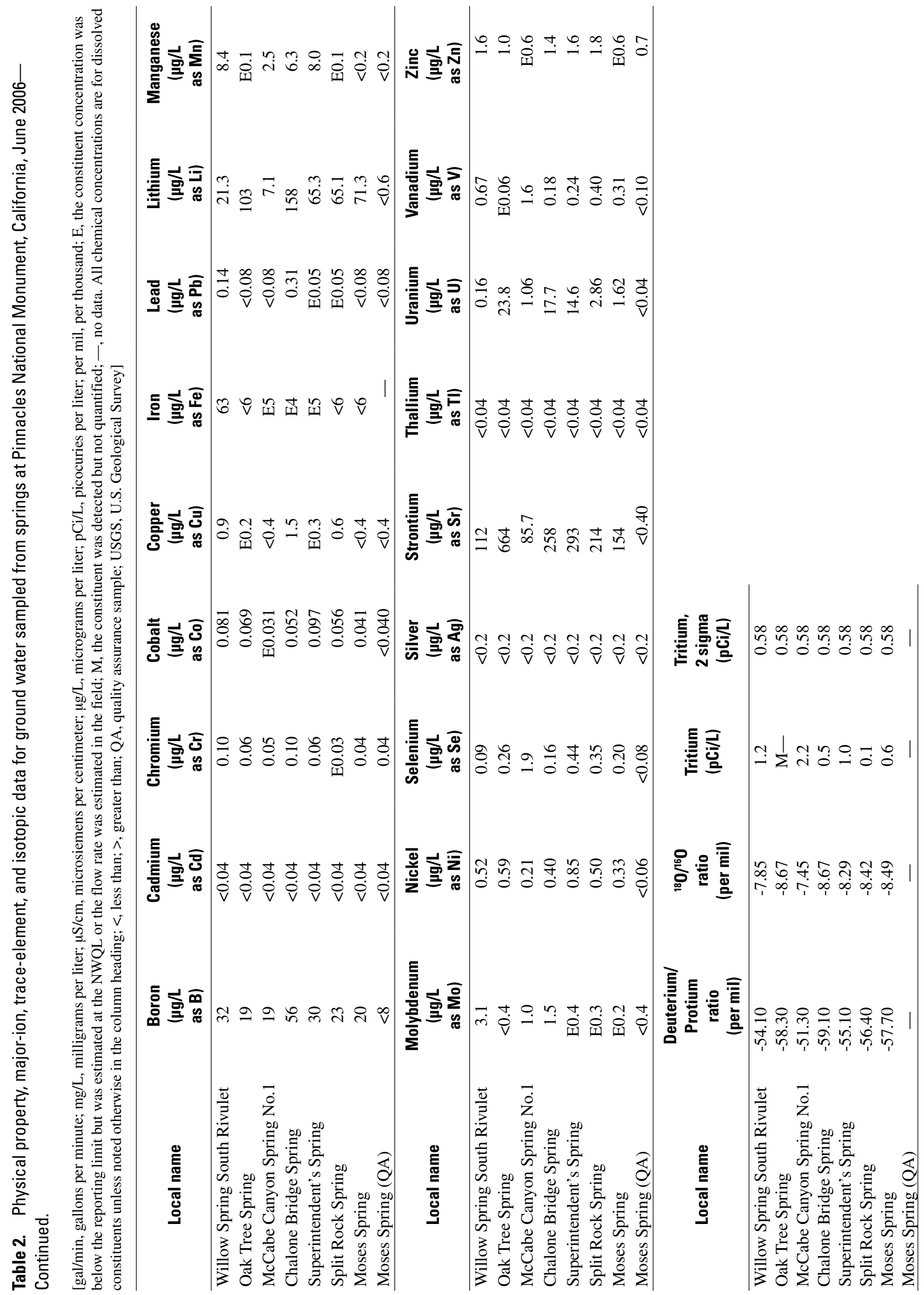




\section{Water-Quality Results}

\section{Physical Properties}

Even though the spring of 2006 was wetter and cooler than is typical, the springs at Pinnacles National Monument discharged water at relatively low rates-from about 0.1 to about 6 gallons per minute. The importance of ground water discharged at low rates from Superintendent's Spring, Chalone Bridge Spring, and Oak Tree Spring to the health of nearby stream environments is uncertain. Ground water discharging from these three springs and McCabe Canyon Spring No. 1 reinfiltrated the soil after flowing downslope approximately $30 \mathrm{ft}, 5 \mathrm{ft}, 15 \mathrm{ft}$, and $70 \mathrm{ft}$ from the respective spring pools. If the infiltrated water reemerges in adjacent stream channels, the springs may provide baseflow to these streams. Although the flow rates of springs were low when they were sampled, the water quality of the sampled springs may be similar to the water quality of other diffuse seepage that provides baseflow to streams.

Water-quality analytical results from spring samples are presented in table 2. Spring $\mathrm{pH}$ was found to be near neutral, ranging only from 6.3 to 7.4 . Considering that the springs are in similar environments and relatively closely spaced, there was substantial variability in spring temperature $\left(14.5-19.5^{\circ} \mathrm{C}\right)$, specific electrical conductance (171-497 $\mu \mathrm{S} / \mathrm{cm})$, and dissolved oxygen concentration (1.5-7.0 mg/L).

\section{Major-Ion Composition}

Hydrologists often classify natural waters by chemical water type, that is, by the dominant cation (positively charged ion) and anion (negatively charged ion), as expressed in milliequivalents per liter. For example, samples from Chalone Bridge Spring and Moses Spring contained more than 50 percent sodium (the dominant cation) and more than 50 percent bicarbonate (the dominant anion) on a milliequivalent-per-liter basis. These samples, therefore, were classified as sodium bicarbonate waters. Likewise, the sample from Oak Tree Spring was a calcium bicarbonate water. The sample from Split Rock Spring does not contain a single dominant cation. This sample was classified as a sodium calcium bicarbonate water because sodium and calcium concentrations together (on a milliequivalent basis) comprised substantially more that 50 percent of the dissolved cations. Because the sodium concentration is greater than the calcium concentration (on a milliequivalent basis) the sodium cation is listed first in the water type designation. Likewise, the sample from Superintendent's Spring was a calcium sodium bicarbonate and the samples from Willow Spring and McCabe Canyon Spring No. 1 were sodium bicarbonate chloride waters. The relative proportion of major cations and anions in each water sample is shown on a trilinear diagram (fig. 18) as a percentage of the total cationic or anionic content measured in milliequivalents per liter. The ionic composition of ground water varied with spring location. Variability in chemical composition of ground water often results from differences in geology, land use, residence time in the aquifer, and other factors.

\section{Oxygen-18 and Deuterium}

The proportion of heavy stable isotopes of oxygen $\left({ }^{18} \mathrm{O}\right)$ and hydrogen $\left({ }^{2} \mathrm{H}\right.$, deuterium) in water molecules can be used to infer the source and evaporative history of water. Atoms of oxygen-18 $\left({ }^{18} \mathrm{O}\right)$ and deuterium $\left({ }^{2} \mathrm{H}\right)$ have more neutrons and a greater atomic mass than do atoms of the more common isotopes, oxygen-16, and hydrogen. The difference in weight results in differences in the physical and chemical behavior of the heavier, less abundant isotopes. Oxygen-18 and deuterium abundances are expressed as ratios of the heavy isotope to the light isotope, in delta notation $(\delta)$, as per mil (parts per thousand) differences, relative to Vienna Standard Mean Ocean Water (VSMOW) (Gonfiantini, 1978). By convention, the value of both oxygen-18 and deuterium abundance ratios in VSMOW is 0 per mil. Oxygen-18 $\left(\delta^{18} \mathrm{O}\right)$ and deuterium $(\delta \mathrm{D})$ ratios, relative to VSMOW, can be measured more precisely than absolute abundance, and these ratios are useful in hydrologic studies (International Atomic Energy Agency, 1981).

Most ground water is meteoric, that is, it is derived from direct infiltration of precipitation or infiltration of surface water that was derived from precipitation. Most precipitation throughout the world originates from the evaporation of seawater. The ratios $\delta^{18} \mathrm{O}$ and $\delta \mathrm{D}$ are relatively constant in atmospheric moisture at given latitudes over the oceans. Water molecules composed of oxygen-18 and deuterium atoms need slightly more energy to evaporate than water molecules composed of lighter oxygen $\left({ }^{16} \mathrm{O}\right)$ and hydrogen $\left({ }^{1} \mathrm{H}\right)$ atoms. Thus, atmospheric moisture over the oceans is slightly depleted in oxygen-18 and deuterium, compared to VSMOW. Thermodynamic processes slightly favor the condensation of water vapor containing oxygen-18 and deuterium. Condensation of water vapor containing oxygen-18 and deuterium occurs at higher temperatures than condensation of water vapor containing ${ }^{16} \mathrm{O}$ and ${ }^{1} \mathrm{H}$. As water droplets repeatedly undergo evaporation and condensation, the aqueous phase becomes isotopically heavier and the vapor phase becomes isotopically lighter. Generally, as atmospheric moisture moves inland from coastal areas, the ratio of the heavy isotopes to the lighter isotopes decreases. Heavy isotopes are more concentrated during initial precipitation, which occurs at lower altitudes in coastal areas, and most depleted during later precipitation, which occurs inland at higher altitudes. Oxygen-18 and deuterium are affected similarly by this isotopic fractionation process; a plot of the isotopic ratios of oxygen-18 to deuterium in precipitation is a straight line with a slope similar to the global meteoric water line (Craig, 1961; Gat and Gonfiantini, 1981). The position of a stable-isotopic analysis from a precipitation sample, relative to the line of isotopic fractionation, is controlled by air temperature and storm duration. 


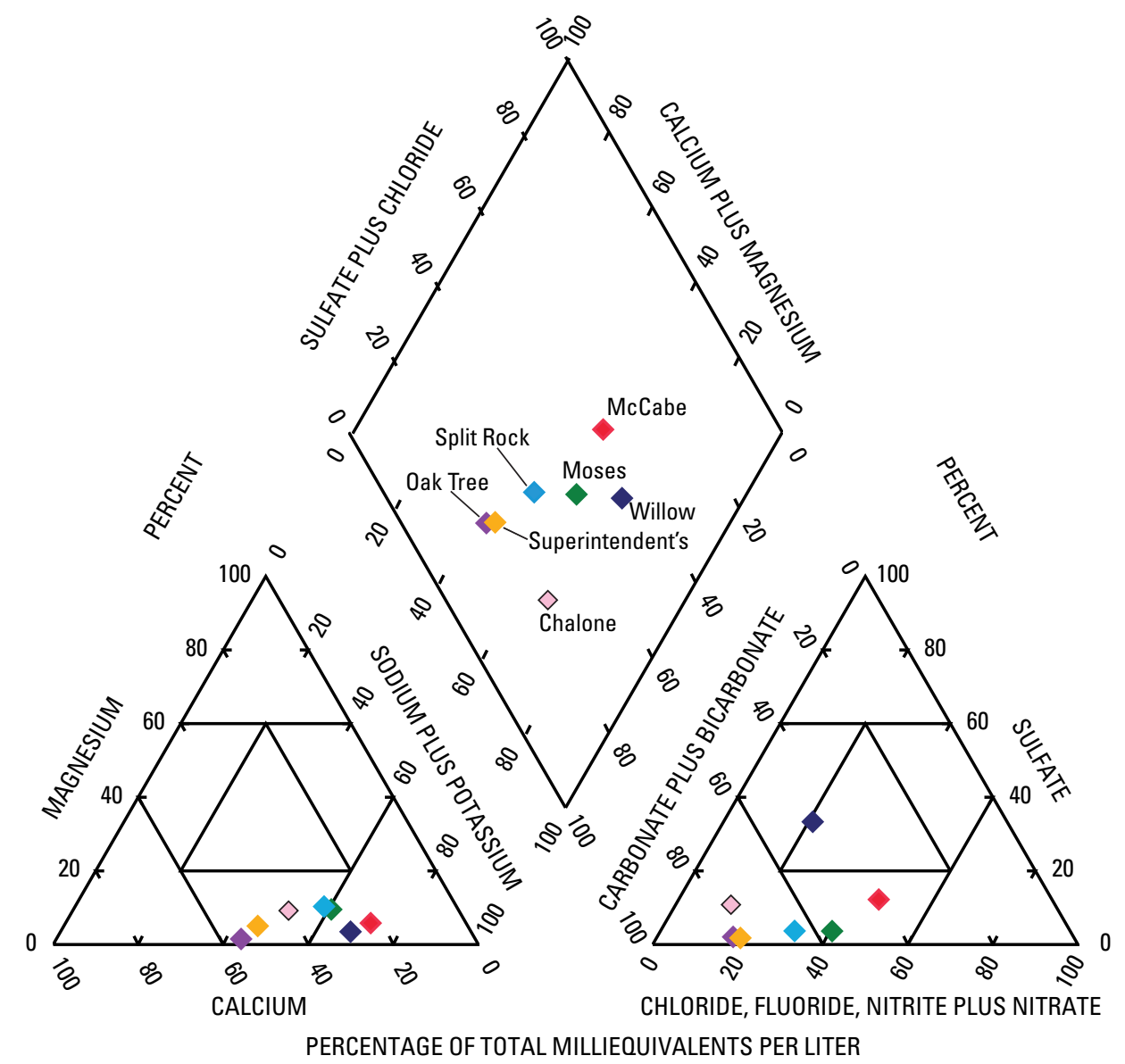

Figure 18. Major-ion composition of samples from springs in Pinnacles National Monument in June 2006.

Often, the isotopic composition of ground-water samples collected from wells and springs in the same general area plot on a straight line (the local ground-water line) representing the variability of isotopic composition of local precipitation. Waters with isotopic compositions that plot low on the local ground-water line likely condensed at cooler temperatures-at a higher altitude or in a cooler climate long ago-than waters with isotopic compositions plotting higher on the line. Isotopic compositions that plot below and to the right of a local ground-water line likely indicate that the water sampled has undergone some evaporation since falling as precipitation.

Figure 19 shows the relation between oxygen-18 and deuterium for all ground-water samples collected from springs at Pinnacles National Monument by the USGS. Too few samples were collected to accurately define a local ground-water line, but most samples plot linearly between the global meteoric water line and a line defined by precipitation collected at Santa Maria, California (International Atomic Energy Agency, 1981) about 110 miles southeast from Pinnacles National Monument.

\section{Tritium}

Tritium $\left({ }^{3} \mathrm{H}\right)$ is a naturally occurring radioactive isotope of hydrogen that has a half-life of 12.43 years. Tritium is produced naturally by the interaction of cosmic rays with nitrogen and oxygen in the atmosphere. Tritium exists in the atmosphere as tritiated water and is transferred from the atmosphere to the sea-surface through vapor exchange and rainfall. In this report, tritium was measured in picocuries per liter $(\mathrm{pCi} / \mathrm{L}) ; 1 \mathrm{pCi} / \mathrm{L}$ is equivalent to 1 tritium atom in about 1,018 atoms of hydrogen. Prior to 1952, the tritium concentration in precipitation in coastal California ranged from 9.6 to $16 \mathrm{pCi} / \mathrm{L}$ (R. Michel, USGS, oral commun., 2006). About $800 \mathrm{~kg}$ of tritium was released to the atmosphere as a result of the atmospheric testing of nuclear weapons during 1952-62 (Michel, 1976), and the tritium concentration of precipitation increased to a maximum of about $3,840 \mathrm{pCi} / \mathrm{L}$. After the cessation of atmospheric testing of nuclear weapons in 1962, the tritium concentration of precipitation decreased;

present-day tritium levels in precipitation are near the pre1952 levels. Because tritium is part of the water molecule, tritium is not affected by reactions other than radioactive 
decay, and-neglecting the effects of dispersion and mixing with older or younger waters-tritium is an excellent tracer of the movement of ground water recharged fewer than 50 years before present. Figure 20 shows tritium concentrations for samples collected from springs at Pinnacles National Monument (table 2). These samples are plotted at zero years on the time scale, that is, present day at the time of the sampling. For comparison with tritium concentrations in the spring samples, time-decayed tritium concentrations were calculated for water that contains levels of tritium similar to background levels measured in precipitation falling in central coastal California (9.6-16 pCi/L). These calculations are plotted as theoretical decay curves (fig. 20) that describe the tritium concentration remaining in water that initially (at year zero) had tritium concentrations of 9.6 and $16 \mathrm{pCi} / \mathrm{L}$. The decay curves illustrate the changing tritium concentration in recharge water that slowly moves through the ground-water-flow system. Because tritium concentrations in the initial waters for the decay curve calculations contained only background levels of tritium the area between the two curves in figure 20 represents the likely tritium concentration range for precipitation that occurred during periods when atmospheric moisture was not affected by nuclear tests. Tritium concentrations plotting below the two background decay curves represent old water that mostly is unaffected by infiltration of post-1952 rainwater.

\section{Trace Elements and Nutrients}

A statistical summary of water-quality results is presented in table 3, along with U.S. Environmental Protection Agency (USEPA) and California Department of Health Services (CADHS) standards for drinking water. The standards provide a basis for evaluating the results of this study.

In general, concentrations of chemical constituents in spring waters sampled for this study were lower than USEPA and CADHS drinking-water standards and USEPA recommended water-quality criteria for freshwater aquatic life. However, the concentrations of dissolved arsenic in Oak Tree Spring, Split Rock Spring, and Moses Spring of 19.2, 15.5, and $10.9 \mu \mathrm{g} / \mathrm{L}$, respectively, were above the new USEPA Maximum Contaminant Level (MCL) for arsenic in drinking water that took effect on January 23, 2006 (U.S. Environmental Protection Agency, 2006a). Historically, Oak Tree Spring and Split Rock Spring were used as sources of drinking water at the Monument. Until recently, the concentration of arsenic in these springs would not have exceeded the Federal MCL. The Federal MCL, for dissolved arsenic in drinking water was lowered from $50 \mu \mathrm{g} / \mathrm{L}$ to $10 \mu \mathrm{g} / \mathrm{L}$ in January 2006 (U.S. Environmental Protection Agency, 2006a). The state of California complies with the Federal MCL with respect to monitoring requirements and is expected to adopt a revised

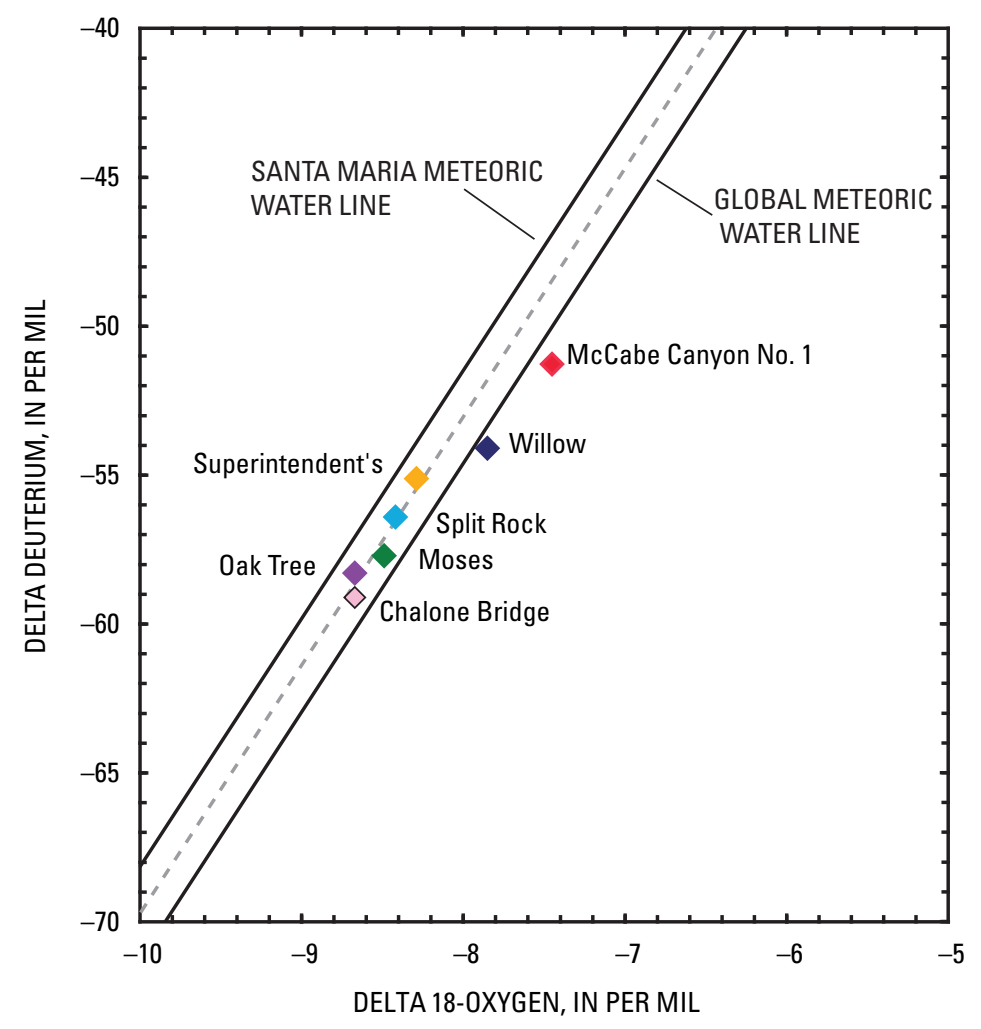

Figure 19. Stable isotopic composition of samples from springs in Pinnacles National Monument in June 2006.

(The dashed line may represent the trend of the local meteoric ground-water line as suggested by the alignment of samples on the graph.) 
State MCL for arsenic of $10 \mu \mathrm{g} / \mathrm{L}$ during 2007. Historically, Willow Spring also has been used as a source of drinking water; the arsenic concentration of water in Willow Spring South Rivulet $(7.5 \mu \mathrm{g} / \mathrm{L})$ was lower than the federal MCL. The concentrations of dissolved uranium in all spring samples were below the USEPA MCL for drinking water, $30 \mu \mathrm{g} / \mathrm{L}$, although the uranium concentration in samples from Oak Tree Spring $(23.8 \mu \mathrm{g} / \mathrm{L})$, Superintendents Spring $(14.6 \mu \mathrm{g} / \mathrm{L})$, and Chalone Bridge Spring $(17.7 \mu \mathrm{g} / \mathrm{L})$ were higher than in samples collected at the other four springs (median concentration,

\section{$1.34 \mu \mathrm{g} / \mathrm{L})$.}

Nutrient concentrations in all samples were lower than USEPA and CADHS drinking water standards and USEPArecommended water-quality criteria for freshwater aquatic life. The highest concentration of dissolved nitrate plus nitrite was in the sample from McCabe Canyon Spring No. 1, $2.93 \mathrm{mg} / \mathrm{L}$ (as N), which is close to the estimated national background nitrate concentration in ground water of $2 \mathrm{mg} / \mathrm{L}$ (Mueller and Helsel, 1996).
The concentrations of all constituents in the field blank (table 2) were less than minimum reporting limits, except for a chromium concentration of $0.04 \mu \mathrm{g} / \mathrm{L}$ (equal to the reporting level) and a zinc concentration of $0.7 \mu \mathrm{g} / \mathrm{L}$ (reporting level: $0.6 \mu \mathrm{g} / \mathrm{L}$ ). The absence of appreciable trace element and nutrient concentrations in the field blank indicates that sampling techniques likely were sufficiently rigorous, and sampling equipment sufficiently clean, to preclude cross-contamination of ground water collected from springs during sampling.

The percent difference in the sum of dissolved cations and anions (in milliequivalents per liter) for all the samples was small (less than \pm 3 percent), indicating that spring waters are electrically balanced and that laboratory analytical techniques likely produced valid data.

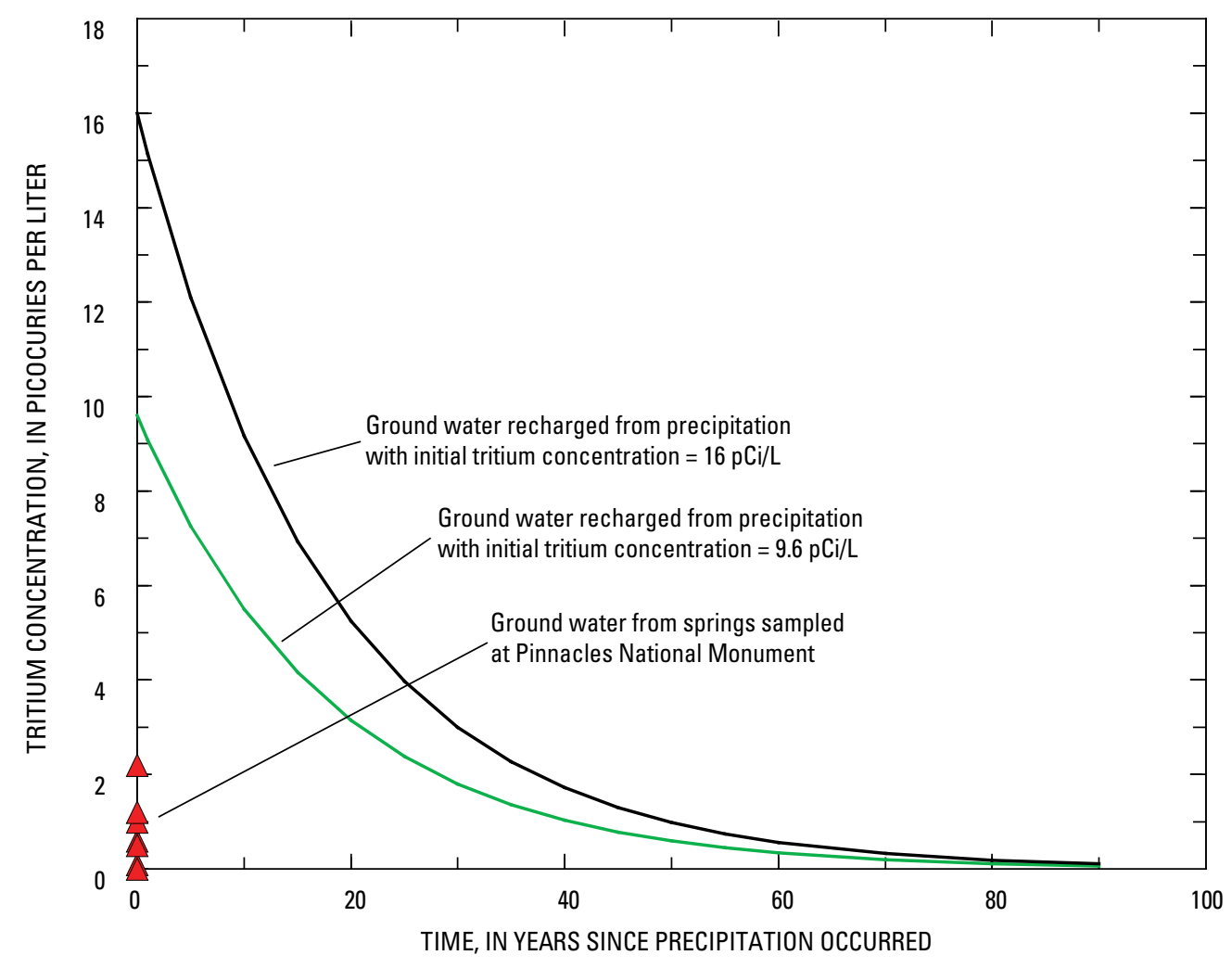

Figure 20. The concentrations of tritium in ground water sampled from springs in Pinnacles National Monument in June 2006 are shown as triangles plotted at zero years, or present day at the time of this study, and the concentration range of tritium that remained in water that fell as precipitation in central coastal California when tritium concentrations in atmospheric water were at background levels between 9.6 and $16 \mathrm{pCi} / \mathrm{L}$ (green and black lines respectively). 
Table 3. Statistical summary of the concentration of major ions, trace elements, nutrients, and isotopes in spring samples, type of comparison threshold for drinking water and the corresponding threshold level, and threshold levels for freshwater aquatic life.

[Threshold levels are maximum permissible levels unless otherwise indicated (For example, the alkalinity CCC for freshwater aquatic life indicates that the alkalinity concentration should be greater than $20 \mathrm{mg} / \mathrm{L}$ as $\mathrm{CaCO}_{3}$; HA-L, lifetime health advisory (U.S. Environmental Protection Agency, 2006b); MCL-CA, California Department of Health Services Maximum Contaminant Level (California Department of Health Services, 2005); MCL-US, U.S. Environmental Protection Agency Maximum Contaminant Level (U.S. Environmental Protection Agency, 2006b); MCLtt-US, action level for treatment technique (U.S. Environmental Protection Agency, 2006b); SMCL-US, U.S. Environmental Protection Agency Secondary Maximum Contaminant Level (U.S. Environmental Protection Agency, 2006b); CCC, Criterion Continuous Concentration (U.S. Environmental Protection Agency, 2006c); CMC, Criterion Maximum Concentration (U.S. Environmental Protection Agency, 2006c); n/a, not applicable; E, value is estimated at or less than USGS reporting limit, or estimated flow rate; M, constituent detected but not quantified; gal/min, gallons per minute; $\mu \mathrm{S} / \mathrm{cm}$, microsiemens per centimeter; $\mathrm{mg} / \mathrm{L}$, milligrams per liter; $\mathrm{pCi} / \mathrm{L}$, picocuries per liter; $\mu \mathrm{g} / \mathrm{L}$,

micrograms per liter; <, less than; >, greater than]

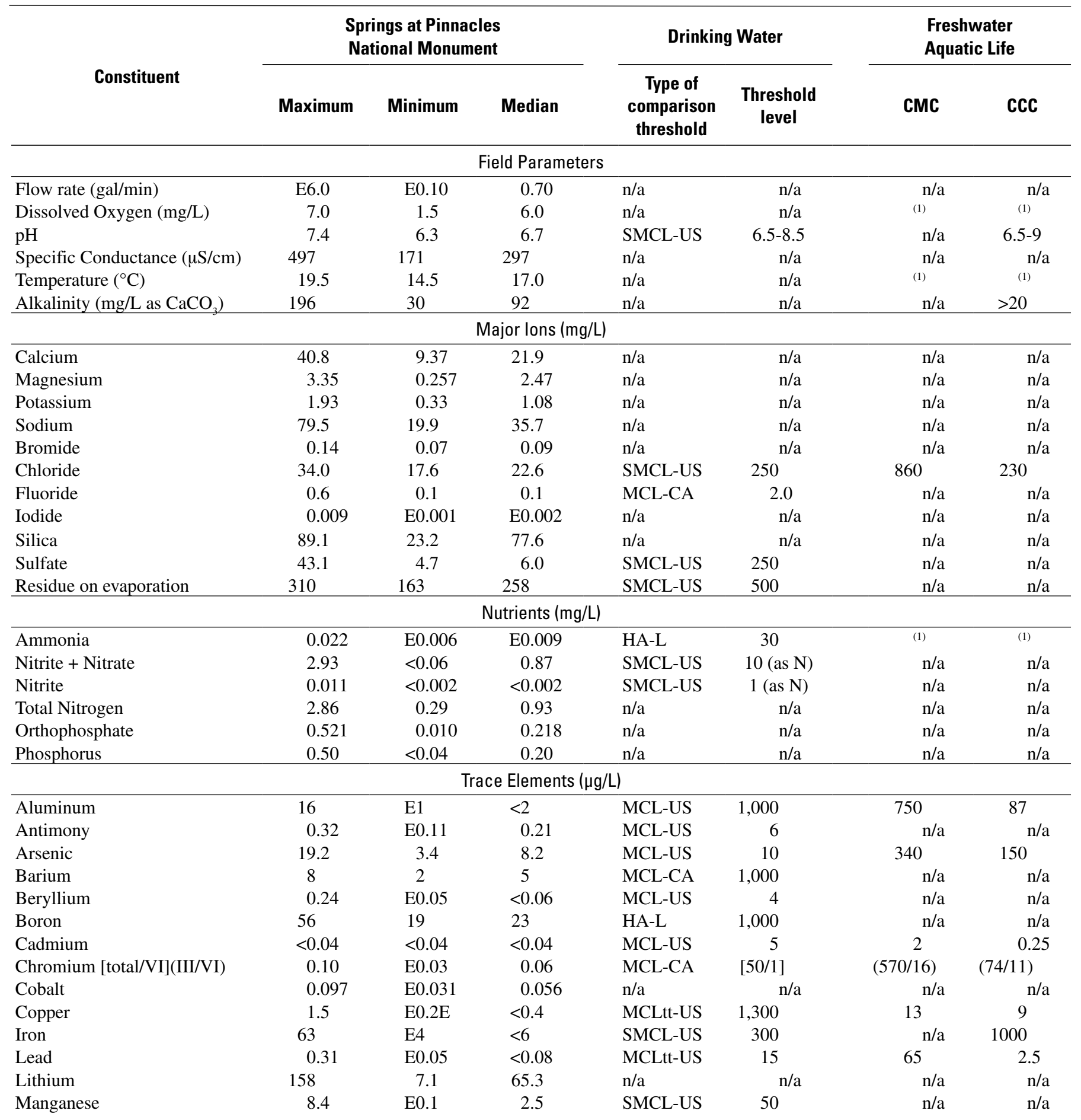


Table 3. Statistical summary of the concentration of major ions, trace elements, nutrients, and isotopes in spring samples, type of comparison threshold for drinking water and the corresponding threshold level, and threshold levels for freshwater aquatic lifeContinued.

[Threshold levels are maximum permissible levels unless otherwise indicated (For example, the alkalinity CCC for freshwater aquatic life indicates that the alkalinity concentration should be greater than $20 \mathrm{mg} / \mathrm{L}$ as $\mathrm{CaCO}_{3}$; HA-L, lifetime health advisory (U.S. Environmental Protection Agency, 2006b); MCLCA, California Department of Health Services Maximum Contaminant Level (California Department of Health Services, 2005); MCL-US, U.S. Environmental Protection Agency Maximum Contaminant Level (U.S. Environmental Protection Agency, 2006b); MCLtt-US, action level for treatment technique (U.S. Environmental Protection Agency, 2006b); SMCL-US, U.S. Environmental Protection Agency Secondary Maximum Contaminant Level (U.S. Environmental Protection Agency, 2006b); CCC, Criterion Continuous Concentration (U.S. Environmental Protection Agency, 2006c); CMC, Criterion Maximum Concentration (U.S. Environmental Protection Agency, 2006c); n/a, not applicable; E, value is estimated at or less than USGS reporting limit, or estimated flow rate; $\mathrm{M}$, constituent detected but not quantified; gal/min, gallons per minute; $\mu \mathrm{S} / \mathrm{cm}$, microsiemens per centimeter; $\mathrm{mg} / \mathrm{L}$, milligrams per liter; $\mathrm{pCi} / \mathrm{L}$, picocuries per liter; $\mu \mathrm{g} / \mathrm{L}$, micrograms per liter; <, less than; >, greater than]

\begin{tabular}{|c|c|c|c|c|c|c|c|}
\hline \multirow[b]{2}{*}{ Constituent } & \multicolumn{3}{|c|}{$\begin{array}{l}\text { Springs at Pinnacles } \\
\text { National Monument }\end{array}$} & \multicolumn{2}{|c|}{ Drinking Water } & \multicolumn{2}{|c|}{$\begin{array}{l}\text { Freshwater } \\
\text { Aquatic Life }\end{array}$} \\
\hline & Maximum & Minimum & Median & $\begin{array}{l}\text { Type of } \\
\text { comparison } \\
\text { threshold }\end{array}$ & $\begin{array}{l}\text { Threshold } \\
\text { level }\end{array}$ & CMC & CCC \\
\hline \multicolumn{8}{|c|}{ Trace Elements $(\mu \mathrm{g} / \mathrm{L})$-Continued } \\
\hline Molybdenum & 3.1 & E0.2 & E0.4 & HA-L & 40 & $\mathrm{n} / \mathrm{a}$ & $\mathrm{n} / \mathrm{a}$ \\
\hline Selenium & 1.9 & 0.09 & 0.26 & MCL-US & 50 & $\mathrm{n} / \mathrm{a}$ & 5 \\
\hline Silver & $<0.2$ & $<0.2$ & $<0.2$ & HA-L & 100 & 3.2 & $\mathrm{n} / \mathrm{a}$ \\
\hline Strontium & 664 & 85.7 & 214 & HA-L & 4,000 & $\mathrm{n} / \mathrm{a}$ & $\mathrm{n} / \mathrm{a}$ \\
\hline Thallium & $<0.04$ & $<0.04$ & $<0.04$ & MCL-US & 2 & $\mathrm{n} / \mathrm{a}$ & $\mathrm{n} / \mathrm{a}$ \\
\hline Uranium & 23.8 & 0.16 & 2.86 & MCL-US & 30 & $\mathrm{n} / \mathrm{a}$ & $\mathrm{n} / \mathrm{a}$ \\
\hline Vanadium & 1.6 & E0.06 & 0.31 & $\mathrm{n} / \mathrm{a}$ & $\mathrm{n} / \mathrm{a}$ & $\mathrm{n} / \mathrm{a}$ & $\mathrm{n} / \mathrm{a}$ \\
\hline${ }^{18} \mathrm{O} /{ }^{16} \mathrm{O}$ ratio & -7.45 & -8.67 & -8.42 & $\mathrm{n} / \mathrm{a}$ & $\mathrm{n} / \mathrm{a}$ & $\mathrm{n} / \mathrm{a}$ & $\mathrm{n} / \mathrm{a}$ \\
\hline \multicolumn{8}{|c|}{ Radioisotopes (pCi/L) } \\
\hline Tritium & 2.2 & $\mathrm{M}$ & 0.6 & MCL-CA & 20,000 & $\mathrm{n} / \mathrm{a}$ & $\mathrm{n} / \mathrm{a}$ \\
\hline
\end{tabular}

${ }^{1}$ Threshold level dependent on aquatic species, or other chemical or physical constituent (U.S. Environmental Protection Agency, 1986).

\section{Summary}

This data report summarizes the objectives, sampling plan, and sampling and analysis protocols used by the U.S. Geological Survey in conducting the level-one baseline waterquality inventory of springs at Pinnacles National Monument. The resulting water-quality data indicate that the seven sampled springs are of generally good quality, although three of the springs had dissolved arsenic concentrations that were higher than the USEPA drinking water standard of $10 \mu \mathrm{g} / \mathrm{L}$ that took effect on January 23, 2006. The data collected in this study provide baseline water-quality information that can be used in conjunction with future water-quality data to assess temporal chemical trends. The data also provide information that will facilitate future study of ground-water-flow systems, stream-aquifer interactions, and wetlands. Ultimately, these data and future studies will improve the understanding of ground-water-flow systems that must be considered during the resource management decision-making process by National Park Service staff at Pinnacles National Monument.

\section{References Cited}

California Department of Health Services, 2005, MCLs, DLRs, and PHGs for regulated drinking water contaminants, accessed November 8, 2006, at http://www.dhs. ca.gov/ps/ddwem/chemicals/phgs/chemicalinformation/ default.htm

Childress, C.J., Foreman, W.T., Connor, B.F., and Maloney, T.J., 1999, New reporting procedures based on long-term method detection levels and some considerations for interpretations of water-quality data provided by the U.S. Geological Survey National Water Quality Laboratory: U.S. Geological Survey Open-File Report 99-193, 19 p.

Coplen, T.B., Wildman, J.D. and Chen, J., 1991. Improvements in the gaseous hydrogen-water equilibration technique for hydrogen isotope ratio analysis: Analytical Chemistry, v. 63, p. 910-912. 
Craig, Harmon, 1961, Isotopic variation in meteoric waters: Science, v. 133, p. 1702-1703.

Epstein, S. and Mayeda, T., 1953, Variation of O- ${ }^{18}$ content of water from natural sources: Geochimica Cosmochimica Acta, v. 4, p. 213-224.

Faires, L.M., 1993, Methods of analysis by the U.S. Geological Survey National Water Quality Laboratory-Determination of metals in water by inductively coupled plasma-mass spectrometry: U.S. Geological Survey Open-File Report 92-634, 28 p.

Fishman, M.J., 1993, Methods of analysis by the U.S. Geological Survey National Water Quality Laboratory-Determination of inorganic and organic constituents in water and fluvial sediments: U.S. Geological Survey Open-File Report 93-125, $217 \mathrm{p}$.

Fishman, M.J., and Friedman, L.C., 1989, Methods for determination of inorganic substances in water and fluvial sediments: U.S. Geological Survey Techniques of WaterResources Investigations, book 5, chap. A1, 545 p.

Garbarino, J.R., 1999, Methods of analysis by the U.S. Geological Survey National Water Quality Laboratory-Determination of dissolved arsenic, boron, lithium, selenium, strontium, thallium, and vanadium using inductively coupled plasma-mass spectrometry: U.S. Geological Survey Open-File Report 99-093, 31 p.

Garbarino, J.R., Kanagy, L.K., and Cree, M.E., 2006, Determination of elements in natural-water, biota, sediment and soil samples using collision/reaction cell inductively coupled plasma-mass spectrometry: U.S. Geological Survey Techniques and Methods, book 5, sec. B, chap.1, 88 p.

Gat, J.R., and Gonfiantini, R., eds., 1981, Stable isotope Hydrology_Deuterium and oxygen-18 in the water cycle: International Atomic Energy Agency Technical Report Series No. 210, 335 p.

Gilbert, T.W., Behymer, T.D., Castaneda, H.B., Determination of dissolved oxygen in natural and wastewaters: American Laboratory, March 1982, p. 119-134.

Gonfiantini, R., 1978, Standards for stable isotope measurements in natural compounds: Nature, v. 271, p. 534-536.

International Atomic Energy Agency, 1981, Statistical treatment of environmental isotope data in precipitation: Technical Research Report Series No. 206, 255 p.

Maloney, T.J., ed., 2005, Quality management system, U.S. Geological Survey National Water Quality Laboratory: U.S. Geological Survey Open-File Report 2005-1263, version 1.3, accessed December 20, 2006, at http://pubs.usgs.gov/ of/2005/1263/pdf/OFR2005-1263.pdf
Michel, R.L., 1976, Tritium inventories of the world's oceans and their implications: Nature, v. 263, p. 103-106.

Mueller, D.K., and Helsel, D.R., 1996, Nutrients in the nation's waters - Too much of a good thing?: U.S. Geological Survey Circular 1136, 24 p.

Östlund, H.G., 1987, Tritium, in GEOSECS Atlantic, Pacific, and Indian Ocean Expeditions, Vol. 7, Shorebased Data and Graphics, 7-10. (Contains a description of lab methods)

Patton, C.J., Kryskalla, J.R., 2003, Methods of analysis by the U.S. Geological Survey National Water Quality Laboratory: Evaluation of Alkaline Persulfate Digestion as an Alternative to Kjeldahl Digestion for Determination of Total and Dissolved Nitrogen and Phosphorus in Water, WaterResources Investigations Report 03-4174, 33 p.

Patton, C.J., and Truitt, E.P., 1992, Methods of analysis by the U.S. Geological Survey National Water Quality Laboratory-Determination of total phosphorus by a Kjeldahl digestion method and an automated colorimetric finish that includes dialysis: U.S. Geological Survey Open-File Report 92-146, 39 p.

Rantz, S.E., and others, 1982, Measurement and computation of streamflow, Measurement of stage and discharge: U.S. Geological Survey Water-Supply Paper 2175, v. 2, 284 p.

U.S. Environmental Protection Agency, 2006a, Arsenic in drinking water, accessed December 20, 2006, at http://www. epa.gov/safewater/arsenic/index.html

U.S. Environmental Protection Agency, 2006b, 2006 edition of the drinking water standards and health advisories, 12 p., accessed November 8, 2006, at http://www.epa.gov/waterscience/criteria/drinking/dwstandards.pdf

U.S. Environmental Protection Agency, 2006c, National recommended water quality criteria, 24 p., accessed November 8, 2006, at http://www.epa.gov/waterscience/criteria/wqcriteria.html.

U.S. Fish and Wildlife Service, Threatened and endangered species system (TESS), accessed December 21, 2006, at http://ecos.fws.gov/tess public/StartTESS.do

U.S. Geological Survey, 1998, National field manual for the collection of water-quality data: U.S. Geological Survey Techniques of Water-Resources Investigations, book 9, variously paginated. 


\section{Appendix A. Water-Quality Terminology and Parameter Definitions}

Long-Term Method Detection Level (LT-MDL) is a detection level derived by determining the standard deviation of 20 or more MDL spike-sample measurements over an extended period of time. LT-MDL data are collected on a continuous basis to assess year-to-year variations in the LT-MDL (Childress and others, 1999). The LT-MDL controls false positive error (reporting an analyte present when it is not in the sample at a concentration equal to or greater than the reporting level). The chance of falsely reporting a concentration greater than or equal to the LT-MDL for a sample that did not contain the analyte is predicted to be less than or equal to 1 percent. The USGS National Water Quality Laboratory collects quality-control data from selected analytical methods on a continuing basis to determine LT-MDL and establish laboratory reporting levels (LRL). These concentrations are reevaluated annually based on the most current quality-control data and may therefore change. In cases where there is not sufficient quality-control data for a given analytical method, the LT-MDL is the LRL (Childress and others, 1999).

Reporting Level (RL) generally is equal to twice the yearly determined LT-MDL (Childress and others, 1999). The LRL controls false negative error (stating the analyte is not detected when present at or greater than the detection level). The probability of falsely reporting a nondetection for a sample that contained an analyte at a concentration equal to or greater than the RL is predicted to be less than or equal to 1 percent. The value of the RL will be reported with a "less than" $(<)$ remark code for samples in which the analyte was not detected (Childress and others, 1999).

\section{Dissolved Oxygen-field}

1. Parameter name: Dissolved oxygen is molecular oxygen (oxygen gas) dissolved in water.

2. Sample fraction: Dissolved oxygen samples were taken from a sample cup by immediate transfer into an ampoule to minimize aeration or other sources of contamination.

3. Measurement units: Dissolved oxygen is reported as milligrams per liter ( $\mathrm{mg} / \mathrm{L})$.

4. Field or lab measurement: Dissolved oxygen measurements were conducted in the field.

5. Value type: Actual

6. Description of sample preparation procedure: CHEMet ampoules were filled from a $25-\mathrm{mL}$ sample cup, the ampoule was inverted several times to mix its contents, after 2 minutes the ampoule was held up to the color comparator beneath a bright source of light. The concentration of dissolved oxygen is determined by color matching the test ampoule to the color comparator.

7. Description of sample transport/preservation: Dissolved oxygen measurements were made in the field. Preservation and transportation of water sampled were not necessary.
8. Lab analytical method/procedure name, source citation, and ID: Indigo Carmine-ASTM D 888-87, Colorimetric Indigo Carmine, Test Method A (Gilbert and others, 1982).

9. Name and model number of field equipment: CHEMetrics, CHEMets Kit K-7512 was used in this field study.

10. Maximum and minimum quantification limits for the method or procedure:

a. Range: $1-12 \mathrm{mg} / \mathrm{L}$

b. Resolution: $0.5 \mathrm{mg} / \mathrm{L}$

\section{pH-field}

1. Parameter name: $\mathrm{pH}$ is a measure representing the negative base-10 logarithm of hydrogen-ion activity of a solution in moles per liter: $\mathrm{pH}=-\log _{10}\left(a_{\mathrm{H}+}\right)$

2. Sample fraction: $\mathrm{pH}$ for this study was measured on unfiltered water samples.

3. Measurement units: $\mathrm{pH}$ is reported on a scale that ranges from 0 to 14 and is directly related to the ratio of hydrogen $\left(\mathrm{H}^{+}\right)$and hydroxyl $\left(\mathrm{OH}^{-}\right)$ion activity at a given temperature.

4. Field or lab measurement: $\mathrm{pH}$ measurements were made in the field.

5. Value type: Actual.

6. Description of sample preparation procedure: The $\mathrm{pH}$ meter was checked and calibrated twice daily in the field using $\mathrm{pH}$ buffers ( $\mathrm{pH} 7$ and $\mathrm{pH} 10$ or $\mathrm{pH} 4)$. Buffers were allowed to equilibrate to approximate sample temperatures prior to calibration of the instrument. $\mathrm{pH}$ was measured either directly in the source or, when water depth was inadequate, from a beaker of sample water. The electrode was allowed to equilibrate until the $\mathrm{pH}$ reading was stable. The probe was rinsed with deionized water and stored upright in electrode storage solution.

7. Description of sample transport/preservation: $\mathrm{pH}$ measurements of sample water were conducted in the field. Preservation and transportation of sample water was not necessary.

8. Lab analytical method/procedure name, source citation, and ID: $\mathrm{pH}$ measurement procedures were followed according to the NFM, chapter A6, section 6.4 (U.S. Geological Survey, 1998).

9. Name and model number of field equipment: Orion model $250 \mathrm{~A}$ temperature-compensated $\mathrm{pH}$ meter with gel-filled ATC combination electrode.

10. Maximum and minimum quantification limits for the method/procedure: $\mathrm{pH}$ measurement
a. Range: -2.00 to 19.99
b. Resolution: $0.01 / 0.1$
c. Relative accuracy: \pm 0.02
d. Slope: 80 to 120 percent
e. Temperature measurement
f. Range: -5.00 to $105.0^{\circ} \mathrm{C}$
g. Resolution: $0.1^{\circ} \mathrm{C}$
h. Relative accuracy: $\pm 1.0^{\circ} \mathrm{C}$ 
Specific [Electrical] Conductance (SC)—field

1. Parameter name: Specific [electrical] conductance is a measure of the capacity of water (or other media) to conduct an electrical current. Electrical conductance of water is a function of the types and quantities of dissolved substances in water.

2. Sample fraction: Specific conductance for this study was measured in unfiltered water samples.

3. Measurement units: Specific conductance is reported in microsiemens per centimeter $(\mu \mathrm{S} / \mathrm{cm})$ at $25^{\circ} \mathrm{C}$.

4. Field or Lab Measurements: Specific conductance for this study was measured in the field.

5. Value type: Actual.

6. Description of sample preparation procedure: The specific conductance instrument was calibrated prior to sample measurements with standards that bracket the expected sample conductance. Standards were equilibrated to the approximate sample temperature. Measurements were made either directly from the source or when water depth was inadequate, from a beaker of sample water. The conductivity probe was immersed in sample water until it equilibrated to sample temperature. The probe was stored in a bottle containing deionized water.

7. Description of sample transport/preservation: Specific conductance of sample water was measured in the field. Preservation and transportation of sample water was not necessary.

8. Lab analytical method/procedure name, source citation, and ID: Specific conductance measurement procedures were followed according to the NFM, chapter A6, section 6.3 (U.S. Geological Survey, 1998).

9. Name and model number of field equipment: ColeParmer model 1481-61 temperature-compensated specificconductance meter with probe model 01481-64, platinum dip-type sensor.

10. Maximum and minimum quantification limits for the method/procedure:

Conductivity range: 0-200,000 $\mu \mathrm{S} / \mathrm{cm}$ (microsiemens per centimeter)

Temperature compensation:

Temperature coefficient: 2 percent per degree Celsius

Reference temperature: $25^{\circ} \mathrm{C}$

Compensation range: $5-45^{\circ} \mathrm{C}$

Temperature range: $5-45^{\circ} \mathrm{C}$

\section{Alkalinity-field}

1. Parameter name: Alkalinity refers to the acid-neutralizing capacity of solutes in a water sample. Alkalinity, thus, consists of the sum of titratable carbonate and noncarbonate chemical species in a filtered sample. In most aqueous systems, alkalinity is controlled by carbonate chemistry and is mainly attributed to bicarbonate $\left(\mathrm{HCO}_{3}\right)$ ion, with lesser contributions by carbonate $\left(\mathrm{CO}_{3}\right)$ and hydroxide $(\mathrm{OH})$ ions.

2. Sample fraction: Alkalinity $\left(\mathrm{CaCO}_{3}\right)$ was measured from filtered water samples.
3. Measurement units: Alkalinity is reported in milligrams per liter $(\mathrm{mg} / \mathrm{L})$ as $\mathrm{CaCO}_{3}$.

4. Field or lab measurement: Alkalinity concentrations were determined in the field.

5. Value type: Actual

6. Description of sample preparation procedure: Sample water was syringe filtered through a disposable 0.45-micron pore disk filter into a 500-mL polyethylene bottle and tightly capped without headspace. (At Superintendent's Spring, USGS Site ID 362856121103801 and Chalone Bridge Spring, USGS Site ID 362912121101101—disposable 0.45-micron pore capsule filters were used due to excess turbidity). Sample bottles previously had been lab-rinsed with distilled water and transported to the field half filled with distilled water. In the field, the bottle was emptied and then rinsed once with filtered sample water.

7. Description of sample transport/preservation: Samples were stored on ice in an insulated container and transported by backpack from the collection sites to an ice filled cooler in a field vehicle at the trailhead. Prior to titration the samples were transferred to a refrigerator. Samples were titrated on the evening of their collection at field technicians' lodging usually within 5 or 6 hours of sample collection. Samples were allowed to equilibrate to room temperature before titration.

8. Lab analytical method/procedure name, source citation, and ID: Alkalinity measurement procedures were followed according to the NFM, chapter A6, section 6.6 (U.S. Geological Survey, 1998).

9. Name and model number of field equipment: Hach Digital Titrator, Model 16900-01.

10. Maximum and minimum quantification limits for the method or procedure: This method is suitable for water containing alkalinity regardless of concentration; however, if the Hach Digital Titrator is used with $0.16 \mathrm{~N}$ sulfuric acid solution, as was done for this study, the minimum quantification limit is $1 \mathrm{mg} / \mathrm{L}$.

11. Method/procedure detection limit: The current long-term method detection limit for alkalinity determined at the USGS NWQL is $1 \mathrm{mg} / \mathrm{L}$.

\section{Calcium}

1. Parameter name: Calcium (calcium as $\mathrm{Ca}$ ).

2. Sample fraction: Calcium analyses are performed on filtered water samples.

3. Measurement units: Calcium concentrations are reported in milligrams per liter $(\mathrm{mg} / \mathrm{L})$.

4. Field or lab measurement: Measurement of calcium concentrations was conducted at the U.S. Geological Survey (USGS) National Water Quality Laboratory (NWQL) in Lakewood, Colorado.

5. Value type: Actual. 
6. Description of sample preparation procedure:

Sample water was syringe filtered through a disposable 0.45 -micron pore disk filter into a $250-\mathrm{mL}$ polyethylene, acidrinsed bottle. The bottle previously had been lab-rinsed with distilled water and transported to the field half filled with distilled water. In the field, the bottle was emptied and then rinsed once with filtered sample water. (At Superintendent's Spring, USGS Site ID 362856121103801 and Chalone Bridge Spring, USGS Site ID 362912121101101-disposable 0.45-micron pore capsule filters were used due to excess turbidity).

7. Description of sample transport/preservation: After collection, the sample was acidified with nitric acid $\left(\mathrm{HNO}_{3}\right)$ to a $\mathrm{pH}$ of less than 2 . The bottle was sealed in a plastic bag and packed into a cooler, without ice, for shipment to the NWQL.

8. Lab analytical method/procedure name, source citation, and ID: NWQL Method I-147287, Schedule 2750: Major Ions; Lab code 659: Calcium, using inductively coupled plasma (ICP), atomic emission spectrometry (Fishman, 1993).

9. Maximum and minimum quantification limits for the method or procedure: This method may be used to analyze water containing from 0.01 to $25 \mathrm{mg} / \mathrm{L}$ of calcium for water that has a measured specific conductance of less than 2,000 $\mu \mathrm{S} / \mathrm{cm}$. Samples containing analyte concentrations greater than the maximum concentration limit can be analyzed for calcium if the sample is diluted, and if after dilution the specific conductance is less than $2,000 \mu \mathrm{S} / \mathrm{cm}$.

10. Method/procedure detection limit: At the time of this study, the long-term method detection limit (LT-MDL) for calcium was $0.01 \mathrm{mg} / \mathrm{L}$. The reporting level (RL) was $0.02 \mathrm{mg} / \mathrm{L}$.

\section{Magnesium}

1. Parameter name: Magnesium (magnesium as $\mathrm{Mg}$ ).

2. Sample fraction: Magnesium analyses are performed on filtered water samples.

3. Measurement units: Magnesium concentrations are reported in milligrams per liter $(\mathrm{mg} / \mathrm{L})$.

4. Field or lab measurement: Measurement of magnesium concentrations was analyzed at the USGS NWQL in Lakewood, Colorado.

5. Value type: Actual.

6. Description of sample preparation procedure: Sample water was syringe filtered through a disposable 0.45 -micron pore disk filter into a 250 -mL polyethylene, acidrinsed bottle. The bottle previously had been lab-rinsed with distilled water and transported to the field half filled with distilled water. In the field, the bottle was emptied and then rinsed once with filtered sample water. (At Superintendent's Spring, USGS Site ID 362856121103801 and Chalone Bridge Spring, USGS Site ID 362912121101101-disposable 0.45-micron pore capsule filters were used due to excess turbidity).

7. Description of sample transport/preservation: After collection, the sample was acidified with nitric acid $\left(\mathrm{HNO}_{3}\right)$ to a $\mathrm{pH}$ of less than 2 . The bottle was sealed in a plastic bag and packed into a cooler, without ice, for shipment to the NWQL.
8. Lab analytical method/procedure name, source citation, and ID: NWQL Method I-147287, Schedule 2750: Major Ions; Lab code 663: Magnesium, using inductively coupled plasma (ICP), atomic emission spectrometry (Fishman, 1993).

9. Maximum and minimum quantification limits for the method or procedure: This method may be used to analyze water containing from 0.004 to $5 \mathrm{mg} / \mathrm{L}$ of magnesium for water that has a measured specific conductance of less than $2,000 \mu \mathrm{S} / \mathrm{cm}$. Samples containing analyte concentrations greater than the maximum concentration limit can be analyzed for magnesium if the sample is diluted, and if after dilution the specific conductance is less than $2,000 \mu \mathrm{S} / \mathrm{cm}$.

10. Method/procedure detection level: At the time of this study, the long-term method detection level (LT-MDL) for magnesium was $0.004 \mathrm{mg} / \mathrm{L}$. The reporting level (RL) was $0.008 \mathrm{mg} / \mathrm{L}$.

\section{Potassium}

1. Parameter name: Potassium (potassium as $\mathrm{K}$ ).

2. Sample fraction: Potassium analyses are performed on filtered water samples.

3. Measurement units: Potassium concentrations are reported in milligrams per liter $(\mathrm{mg} / \mathrm{L})$.

4. Field or lab measurement: Measurement of concentrations of potassium was conducted at the USGS NWQL in Lakewood, Colorado.

5. Value type: Actual.

6. Description of sample preparation procedure: Sample water was syringe filtered through a disposable 0.45 -micron pore disk filter into a 250 - $\mathrm{mL}$ polyethylene, acidrinsed bottle. The bottle previously had been lab-rinsed with distilled water and transported to the field half filled with distilled water. In the field, the bottle was emptied and then rinsed once with filtered sample water. (At Superintendent's Spring, USGS Site ID 362856121103801 and Chalone Bridge Spring, USGS Site ID 362912121101101-disposable 0.45-micron pore capsule filters were used due to excess turbidity).

7. Description of sample transport/preservation: After collection, the sample was acidified with nitric acid $\left(\mathrm{HNO}_{3}\right)$ to a $\mathrm{pH}$ of less than 2 . The bottle was packed into a cooler, without ice, for shipment to the NWQL.

8. Lab analytical method/procedure name, source citation, and ID: NWQL Method I-147287, Schedule 2750: Major Ions; Lab code 2773: Potassium, using inductively coupled plasma (ICP), atomic emission spectrometry (Fishman, 1993).

9. Maximum and minimum quantification limits for the method or procedure: This method may be used to analyze atmospheric precipitation, water, brines, and watersuspended sediment. The analytical ranges for potassium are from 0.08 to $10 \mathrm{mg} / \mathrm{L}$. Sample solutions containing potassium concentrations greater than $10 \mathrm{mg} / \mathrm{L}$ need to be diluted. 
10. Method/procedure detection level: At the time of this study, the long-term method detection level (LT-MDL) for potassium was $0.08 \mathrm{mg} / \mathrm{L}$. The reporting level (RL) was $0.16 \mathrm{mg} / \mathrm{L}$.

\section{Sodium}

1. Parameter name: Sodium (sodium as $\mathrm{Na}$ ).

2. Sample fraction: Sodium analyses are performed on filtered water samples.

3. Measurement units: Sodium concentrations are reported in milligrams per liter $(\mathrm{mg} / \mathrm{L})$.

4. Field or lab measurement: Measurement of concentrations of sodium was conducted at the USGS NWQL in Lakewood, Colorado.

5. Value type: Actual.

6. Description of sample preparation procedure: Sample water was syringe filtered through a disposable 0.45 -micron pore disk filter into a $250-\mathrm{mL}$ polyethylene, acidrinsed bottle. The bottle previously had been lab-rinsed with distilled water and transported to the field half filled with distilled water. In the field, the bottle was emptied and then rinsed once with filtered sample water. (At Superintendent's Spring, USGS Site ID 362856121103801 and Chalone Bridge Spring, USGS Site ID 362912121101101—disposable 0.45-micron pore capsule filters were used due to excess turbidity).

7. Description of sample transport/preservation: After collection, the sample was acidified with nitric acid $\left(\mathrm{HNO}_{3}\right)$ to a pH of less than 2. The bottle was sealed in a plastic bag and packed into a cooler, without ice, for shipment to the NWQL.

8. Lab analytical method/procedure name, source citation, and ID: NWQL Method I-147287, Schedule 2750: Major Ions; Lab code 675: Sodium, using inductively coupled plasma (ICP), atomic emission spectrometry (Fishman, 1993).

9. Maximum and minimum quantification limits for the method or procedure: This method may be used to analyze water containing from 0.10 to $50 \mathrm{mg} / \mathrm{L}$ sodium for water that has a measured specific conductance of less than $2,000 \mu \mathrm{S} / \mathrm{cm}$. Samples containing analyte concentrations greater than the maximum concentration limit can be analyzed for sodium if the sample is diluted and if after dilution the specific conductance is less than $2,000 \mu \mathrm{S} / \mathrm{cm}$.

10. Method/procedure detection level: At the time of this study, the long-term method detection level (LT-MDL) for sodium was $0.10 \mathrm{mg} / \mathrm{L}$. The reporting level (RL) was $0.20 \mathrm{mg} / \mathrm{L}$.

\section{Bromide}

1. Parameter name: Bromide (bromide as $\mathrm{Br}$ )

2. Sample fraction: Bromide analyses are performed on filtered water samples.

3. Measurement units: Bromide concentrations are reported in milligrams per liter $(\mathrm{mg} / \mathrm{L})$.

4. Field or lab measurement: Measurement of concentrations of bromide was conducted at the USGS NWQL in Lakewood, Colorado.

\section{Value type: Actual}

6. Description of sample preparation procedure:

Sample water was syringe filtered through a disposable 0.45 -micron pore disk filter into a $250-\mathrm{mL}$ polyethylene bottle. The bottle previously had been lab-rinsed with distilled water and transported to the field half filled with distilled water. In the field, the bottle was emptied and then rinsed once with filtered sample water. (At Superintendent's Spring, USGS Site ID 362856121103801 and Chalone Bridge Spring, USGS Site ID 362912121101101—disposable 0.45-micron pore capsule filters were used due to excess turbidity).

7. Description of sample transport/preservation: The bottle was sealed in a plastic bag and packed into a cooler, without ice, for shipment to the NWQL.

8. Lab analytical method/procedure name, source citation, and ID: NWQL Method I-2057-85, Schedule 2750: Major Ions; Lab code 3166: Bromide, using ion chromatography.

9. Maximum and minimum quantification limits for the method or procedure: The analytical range for this procedure is 0.02 to $0.4 \mathrm{mg} / \mathrm{L}$. Concentrations greater than $0.4 \mathrm{mg} / \mathrm{L}$ must be diluted.

10. Method/procedure detection level: At the time of this study, the long-term method detection level (LT-MDL) for bromide was $0.01 \mathrm{mg} / \mathrm{L}$. The reporting level (RL) was $0.02 \mathrm{mg} / \mathrm{L}$.

\section{Chloride}

1. Parameter name: Chloride (chloride as $\mathrm{Cl}$ ).

2. Sample fraction: Chloride analyses are performed on filtered water samples.

3. Measurement units: Chloride concentrations are reported in milligrams per liter $(\mathrm{mg} / \mathrm{L})$.

4. Field or lab measurement: Measurement of concentrations of chloride was conducted at the USGS NWQL in Lakewood, Colorado.

5. Value type: Actual

6. Description of sample preparation procedure: Sample water was syringe filtered through a disposable 0.45 -micron pore disk filter into a 250 -mL polyethylene bottle. The bottle previously had been lab-rinsed with distilled water and transported to the field half filled with distilled water. In the field, the bottle was emptied and then rinsed once with filtered sample water. (At Superintendent's Spring, USGS Site ID 362856121103801 and Chalone Bridge Spring, USGS Site ID 362912121101101—disposable 0.45-micron pore capsule filters were used due to excess turbidity).

7. Description of sample transport/preservation: The bottle was sealed in a plastic bag and packed into a cooler, without ice, for shipment to the NWQL.

8. Lab analytical method/procedure name, source citation, and ID: NWQL Method I-205785, Schedule 2750: Major Ions; Lab code 1571: Chloride, using ion chromatography (Fishman and Friedman, 1989). 
9. Maximum and minimum quantification limits for the method or procedure: This method is used to analyze most samples of water, wastewater, and brines containing from 0.10 to $50 \mathrm{mg} / \mathrm{L}$ chloride. Concentrations greater than $50 \mathrm{mg} / \mathrm{L}$ must be diluted.

10. Method/procedure detection level: At the time of this study, the long-term method detection level (LT-MDL) for chloride was $0.10 \mathrm{mg} / \mathrm{L}$. The reporting level (RL) was $0.20 \mathrm{mg} / \mathrm{L}$.

\section{Fluoride}

1. Parameter name: Fluoride (fluoride as $\mathrm{Fl}$ ).

2. Sample fraction: Fluoride analyses are performed on filtered water samples.

3. Measurement units: Fluoride concentrations are reported in milligrams per liter $(\mathrm{mg} / \mathrm{L})$.

4. Field or lab measurement: Measurement of concentrations of fluoride was conducted at the USGS NWQL in Lakewood, Colorado.

5. Value type: Actual

6. Description of sample preparation procedure: Sample water was syringe filtered through a disposable 0.45 -micron pore disk filter into a $250-\mathrm{mL}$ polyethylene bottle. The bottle previously had been lab-rinsed with distilled water and transported to the field half filled with distilled water. In the field, the bottle was emptied and then rinsed once with filtered sample water. (At Superintendent's Spring, USGS Site ID 362856121103801 and Chalone Bridge Spring, USGS Site ID 362912121101101—disposable 0.45-micron pore capsule filters were used due to excess turbidity).

7. Description of sample transport/preservation: The bottle was sealed in a plastic bag and packed into a cooler, without ice, for shipment to the NWQL.

8. Lab analytical method/procedure name, source citation, and ID: NWQL Method I-232785, Schedule 2750: Major Ions; Lab code 31: Fluoride, using colorimetry, electrometric, ion-selective electrode, automated-segmented flow (Fishman and Friedman, 1989).

9. Maximum and minimum quantification limits for the method or procedure: This method may be used to analyze water and water-suspended sediment containing from 0.05 to $3.0 \mathrm{mg} / \mathrm{L}$ of fluoride with specific conductivities less than $20,000 \mu \mathrm{S} / \mathrm{cm}$.

10. Method/procedure detection level: At the time of this study, the long-term method detection level (LT-MDL) for fluoride was $0.05 \mathrm{mg} / \mathrm{L}$. The reporting level (RL) was $0.10 \mathrm{mg} / \mathrm{L}$.

\section{Iodide}

1. Parameter name: Iodide (iodide as I).

2. Sample fraction: Iodide analyses are performed on filtered water samples.

3. Measurement units: Iodide concentrations are reported in milligrams per liter $(\mathrm{mg} / \mathrm{L})$.
4. Field or lab measurement: Measurement of concentrations of iodide was conducted at the USGS NWQL in Lakewood, Colorado.

5. Value type: Actual

6. Description of sample preparation procedure: Sample water was syringe filtered through a disposable 0.45 -micron pore disk filter into a $250-\mathrm{mL}$ polyethylene bottle. The bottle previously had been lab-rinsed with distilled water and transported to the field half filled with distilled water. In the field, the bottle was emptied and then rinsed once with filtered sample water. (At Superintendent's Spring, USGS Site ID 362856121103801 and Chalone Bridge Spring, USGS Site ID 362912121101101—disposable 0.45-micron pore capsule filters were used due to excess turbidity).

7. Description of sample transport/preservation: The bottle was sealed in a plastic bag and packed into a cooler, without ice, for shipment to the NWQL.

8. Lab analytical method/procedure name, source citation, and ID: NWQL Method I-237189, Lab code 1202: Iodide, using colorimetry, automated-segmented flow, cericarsenious (Fishman and Friedman, 1989).

9. Maximum and minimum quantification limits for the method or procedure: This method may be used to determine iodide in fresh water and brines containing from 0.001 to $0.060 \mathrm{mg} / \mathrm{L}$ of iodide. Greater concentrations need to be reduced by dilution.

10. Method/procedure detection level: At the time of this study, the long-term method detection level (LT-MDL) for iodide was $0.001 \mathrm{mg} / \mathrm{L}$. The reporting level (RL) was $0.002 \mathrm{mg} / \mathrm{L}$.

Silica

1. Parameter name: Silica as silica dioxide (silica as $\mathrm{SiO}_{2}$ ).

2. Sample fraction: Silica analyses are performed on filtered water samples.

3. Measurement units: Silica concentrations are reported in milligrams per liter ( $\mathrm{mg} / \mathrm{L})$.

4. Field or lab measurement: Measurement of concentrations of silica was conducted at the USGS NWQL in Lakewood, Colorado.

5. Value type: Actual.

6. Description of sample preparation procedure: Sample water was syringe filtered through a disposable 0.45 -micron pore disk filter into a $250-\mathrm{mL}$ polyethylene, acidrinsed bottle. The bottle previously had been lab-rinsed with distilled water and transported to the field half filled with distilled water. In the field, the bottle was emptied and then rinsed once with filtered sample water. (At Superintendent's Spring, USGS Site ID 362856121103801 and Chalone Bridge Spring, USGS Site ID 362912121101101—disposable 0.45-micron pore capsule filters were used due to excess turbidity). 
7. Description of sample transport/preservation: After collection, the sample was acidified with nitric acid $\left(\mathrm{HNO}_{3}\right)$ to a $\mathrm{pH}$ of less than 2 . The bottle was sealed in a plastic bag and packed into a cooler, without ice, for shipment to the NWQL.

8. Lab analytical method/procedure name, source citation, and ID: NWQL Method I-147287, Schedule 2750: Major Ions; Lab code 667, Silica, using inductively coupled plasma (ICP), atomic emission spectrometry (Fishman, 1993).

9. Maximum and minimum quantification limits for the method or procedure: This method may be used to analyze water containing from 0.01 to $100 \mathrm{mg} / \mathrm{L}$ of silica for water that has a measured specific conductance of less than $2,000 \mu \mathrm{S} / \mathrm{cm}$. Samples containing analyte concentrations greater than the maximum concentration limit can be analyzed for silica if the sample is diluted, and if after dilution the specific conductance is less than $2,000 \mu \mathrm{S} / \mathrm{cm}$.

10. Method/procedure detection level: At the time of this study, the long-term method detection level (LT-MDL) for silica was $0.02 \mathrm{mg} / \mathrm{L}$. The reporting level (RL) was $0.04 \mathrm{mg} / \mathrm{L}$.

\section{Sulfate}

1. Parameter name: Sulfate (sulfate as $\mathrm{SO}_{4}$ ).

2. Sample fraction: Sulfate analyses are performed on filtered water samples.

3. Measurement units: Sulfate concentrations are reported in milligrams per liter $(\mathrm{mg} / \mathrm{L})$.

4. Field or lab measurement: Measurement of concentrations of sulfate was conducted at the USGS NWQL in Lakewood, Colorado.

\section{Value type: Actual}

6. Description of sample preparation procedure: Sample water was syringe filtered through a disposable 0.45 -micron pore disk filter into a $250-\mathrm{mL}$ polyethylene bottle. The bottle previously had been lab-rinsed with distilled water and transported to the field half filled with distilled water. In the field, the bottle was emptied and then rinsed once with filtered sample water. (At Superintendent's Spring, USGS Site ID 362856121103801 and Chalone Bridge Spring, USGS Site ID 362912121101101—disposable 0.45-micron pore capsule filters were used due to excess turbidity).

7. Description of sample transport/preservation: The bottle was sealed in a plastic bag and packed into a cooler, without ice, for shipment to the NWQL.

8. Lab analytical method/procedure name, source citation, and ID: NWQL Method I-205785, Schedule 2750: Major Ions; Lab code 1572: Sulfate, using ion chromatography (Fishman and Friedman, 1989).

9. Maximum and minimum quantification limits for the method or procedure: This method is used to analyze most samples of water, wastewater, and brines containing from 0.09 to $100 \mathrm{mg} / \mathrm{L}$ sulfate. Concentrations greater than $100 \mathrm{mg} / \mathrm{L}$ must be diluted.

10. Method/procedure detection level: At the time of this study, the long-term method detection level (LT-MDL) for sulfate was $0.09 \mathrm{mg} / \mathrm{L}$. The reporting level (RL) was $0.18 \mathrm{mg} / \mathrm{L}$.
Residue on Evaporation (ROE) at $\mathbf{1 8 0}^{\circ} \mathrm{C}$

1. Parameter name: Residue on evaporation (total dissolved solids).

2. Sample fraction: ROE analyses are performed on filtered water samples.

3. Measurement units: ROE concentrations are reported in milligrams per liter $(\mathrm{mg} / \mathrm{L})$.

4. Field or lab measurement: Measurement of concentrations of ROE was conducted at the USGS NWQL in Lakewood, Colorado.

5. Value type: Actual

6. Description of sample preparation procedure: Sample water was syringe filtered through a disposable 0.45 -micron pore disk filter into a 250 -mL polyethylene bottle. The bottle previously had been lab-rinsed with distilled water and transported to the field half filled with distilled water. In the field, the bottle was emptied and then rinsed once with filtered sample water. (At Superintendent's Spring, USGS Site ID 362856121103801 and Chalone Bridge Spring, USGS Site ID 362912121101101—disposable 0.45-micron pore capsule filters were used due to excess turbidity).

7. Description of sample transport/preservation: The bottle was sealed in a plastic bag and packed into a cooler, without ice, for shipment to the NWQL.

8. Lab analytical method/procedure name, source citation, and ID: NWQL Method I-175089, Schedule 2750: Major Ions; Lab code 27: ROE, gravimetric (Fishman and Friedman, 1989).

9. Maximum and minimum quantification limits for the method or procedure: The residue-on-evaporation method is applicable to all water regardless of concentration, provided that the residue layer in the evaporation dish is kept sufficiently thin.

10. Method/procedure detection level: At the time of this study, the long-term method detection level was residue on evaporation was $10 \mathrm{mg} / \mathrm{L}$. At the time of this study, the reporting level (RL) was $10 \mathrm{mg} / \mathrm{L}$.

\section{Ammonia}

1. Parameter name: Ammonia (ammonia as $\mathrm{N}$ ).

2. Sample fraction: Ammonia as nitrogen analyses are performed on filtered water samples.

3. Measurement units: Ammonia as nitrogen concentrations are reported in milligrams per liter $(\mathrm{mg} / \mathrm{L})$.

4. Field or lab measurement: Measurement of concentrations of ammonia as nitrogen was conducted at the USGS NWQL in Lakewood, Colorado.

5. Value type: Actual

6. Description of sample preparation procedure: Sample water was syringe filtered through a disposable 0.45 -micron pore disk filter into a 125 -mL brown polyethylene bottle. The bottle previously had been lab-rinsed with distilled water and transported to the field half filled with distilled water. In the field, the bottle was emptied and then rinsed once with filtered sample water. (At Superintendent's Spring, USGS Site ID 362856121103801 and Chalone Bridge Spring, USGS 
Site ID 362912121101101—disposable 0.45-micron pore capsule filters were used due to excess turbidity).

7. Description of sample transport/preservation: The bottle was sealed in a plastic bag and packed into a cooler, with ice (in order to maintain a temperature of $4^{\circ} \mathrm{C}$ ), for prompt shipment to the NWQL.

8. Lab analytical method/procedure name, source citation, and ID: NWQL Method I-2522-90, I-2525-89; Lab Schedule 318: Nutrients, Lab code 3116, ammonia as nitrogen, using colorimetry, DA, salicylate-hypochlorite (Fishman, 1993).

9. Maximum and minimum quantification limits for the method or procedure: This method is used to analyze samples of surface, domestic, and industrial water, and brines containing from 0.01 to $1.5 \mathrm{mg} / \mathrm{L}$ of ammonia-nitrogen. Greater concentrations must be diluted.

10. Method/procedure detection level: At the time of this study, the long-term method detection level (LT-MDL) for ammonia as nitrogen was $0.005 \mathrm{mg} / \mathrm{L}$. The reporting level (RL) was $0.010 \mathrm{mg} / \mathrm{L}$.

\section{Nitrite + Nitrate} N).

1. Parameter name: Nitrite + nitrate (nitrite + nitrate, as

2. Sample fraction: Nitrite + nitrate as nitrogen analyses are performed on filtered water samples.

3. Measurement units: Nitrite + nitrate as nitrogen concentrations are reported in milligrams per liter $(\mathrm{mg} / \mathrm{L})$.

4. Field or lab measurement: Measurement of concentrations of nitrite + nitrate as nitrogen was conducted at the USGS NWQL in Lakewood, Colorado.

5. Value type: Calculated.

6. Description of sample preparation procedure: Sample water was syringe filtered through a disposable 0.45 -micron pore disk filter into a 125 -mL brown polyethylene bottle. The bottle previously had been lab-rinsed with distilled water and transported to the field half filled with distilled water. In the field, the bottle was emptied and then rinsed once with filtered sample water. (At Superintendent's Spring, USGS Site ID 362856121103801 and Chalone Bridge Spring, USGS Site ID 362912121101101—disposable 0.45-micron pore capsule filters were used due to excess turbidity).

7. Description of sample transport/preservation: The bottle was sealed in a plastic bag and packed into a cooler, with ice (in order to maintain a temperature of $4^{\circ} \mathrm{C}$ ), for prompt shipment to the NWQL.

8. Lab analytical method/procedure name, source citation, and ID: NWQL Method I-254590; Lab Schedule 318: Nutrients, Lab code 1975, Nitrite + nitrate as nitrogen, using colorimetry, automated-segmented flow, cadmium reduction - diazotization (Fishman, 1993).

9. Maximum and minimum quantification limits for the method or procedure: This method is used to analyze samples of surface, domestic, and industrial water and brines containing from 0.1 to $5.0 \mathrm{mg} / \mathrm{L}$ of nitrite + nitrate-nitrogen.
10. Method/procedure detection level: At the time of this study, the long-term method detection level (LT-MDL) for nitrite + nitrate (as N) was $0.030 \mathrm{mg} / \mathrm{L}$. The reporting level (RL) was $0.060 \mathrm{mg} / \mathrm{L}$.

\section{Nitrite}

1. Parameter name: Nitrite (nitrite as $\mathrm{N}$ ).

2. Sample fraction: Nitrite as nitrogen analyses are performed on filtered water samples.

3. Measurement units: Nitrite as nitrogen concentrations are reported in milligrams per liter $(\mathrm{mg} / \mathrm{L})$.

4. Field or lab measurement: Measurement of concentrations of nitrite as nitrogen was conducted at the USGS NWQL in Lakewood, Colorado.

5. Value type: Actual

6. Description of sample preparation procedure: Sample water was syringe filtered through a disposable 0.45 -micron pore disk filter into a $125-\mathrm{mL}$ brown polyethylene bottle. The bottle previously had been lab-rinsed with distilled water and transported to the field half filled with distilled water. In the field, the bottle was emptied and then rinsed once with filtered sample water. (At Superintendent's Spring, USGS Site ID 362856121103801 and Chalone Bridge Spring, USGS Site ID 362912121101101—disposable 0.45-micron pore capsule filters were used due to excess turbidity).

7. Description of sample transport/preservation: The bottle was sealed in a plastic bag and packed into a cooler, with ice (in order to maintain a temperature of $4^{\circ} \mathrm{C}$ ), for prompt shipment to the NWQL.

8. Lab analytical method/procedure name, source citation, and ID: NWQL Methods I- 2540-90, I-2542-89; Lab Schedule 318: Nutrients, Lab code 3117, Nitrite as nitrogen, using colorimetry, DA (Fishman and Friedman, 1993).

9. Maximum and minimum quantification limits for the method or procedure: These methods are used to analyze samples of precipitation or natural water containing from 0.001 to $1.0 \mathrm{mg} / \mathrm{L}$ of nitrite-nitrogen. Concentrations greater than $1.0 \mathrm{mg} / \mathrm{L}$ must be diluted.

10. Method/procedure detection level: At the time of this study, the long-term method detection level (LT-MDL) for nitrite (as N) was $0.001 \mathrm{mg} / \mathrm{L}$. The reporting level (RL) was $0.002 \mathrm{mg} / \mathrm{L}$.

\section{Total Nitrogen}

1. Parameter name: Total dissolved nitrogen $\left(\mathrm{NO}_{2}+\mathrm{NO}_{3}+\mathrm{NH}_{3}+\right.$ organic nitrogen, as $\left.\mathrm{N}\right)$

2. Sample fraction: Total dissolved nitrogen analyses are performed on filtered water samples.

3. Measurement units: Total dissolved nitrogen concentrations are reported in milligrams per liter $(\mathrm{mg} / \mathrm{L})$.

4. Field or lab measurement: Measurement of concentrations of total dissolved nitrogen was conducted at the USGS NWQL in Lakewood, Colorado.

5. Value type: Actual 
6. Description of sample preparation procedure: Sample water was syringe filtered through a disposable 0.45 -micron pore disk filter into a 125 - $\mathrm{mL}$ brown polyethylene bottle. The bottle previously had been lab-rinsed with distilled water and transported to the field half filled with distilled water. In the field, the bottle was emptied and then rinsed once with filtered sample water. (At Superintendent's Spring, USGS Site ID 362856121103801 and Chalone Bridge Spring, USGS Site ID 362912121101101—disposable 0.45-micron pore capsule filters were used due to excess turbidity).

7. Description of sample transport/preservation: The bottle was sealed in a plastic bag and packed into a cooler, with ice (in order to maintain a temperature of $4^{\circ} \mathrm{C}$ ), for prompt shipment to the NWQL.

8. Lab analytical method/procedure name, source citation, and ID: NWQL Method I-265003; Lab code 2754, Total dissolved nitrogen, using alkaline persulfate digest (Patton and Kryskalla, 2003).

9. Maximum and minimum quantification limits for the method or procedure: The analytical range for this method is 0.03 to $5.00 \mathrm{mg} / \mathrm{L}$. Greater concentrations must be diluted.

10. Method/procedure detection level: At the time of this study, the long-term method detection level (LT-MDL) for total dissolved nitrogen (as $\mathrm{N}$ ) was $0.03 \mathrm{mg} / \mathrm{L}$. The reporting level (RL) was $0.06 \mathrm{mg} / \mathrm{L}$.

\section{Orthophosphate}

1. Parameter name: Orthophosphate as phosphorus (orthophosphate as P)

2. Sample fraction: Orthophosphate as phosphorus analyses are performed on filtered water samples.

3. Measurement units: Orthophosphate as phosphorus concentrations are reported in milligrams per liter $(\mathrm{mg} / \mathrm{L})$.

4. Field or lab measurement: Measurement of concentrations of Orthophosphate as phosphorus was conducted at the USGS NWQL in Lakewood, Colorado.

\section{Value type: Actual}

6. Description of sample preparation procedure: Sample water was syringe filtered through a disposable 0.45 -micron pore disk filter into a 125 - $\mathrm{mL}$ brown polyethylene bottle. The bottle previously had been lab-rinsed with distilled water and transported to the field half filled with distilled water. In the field, the bottle was emptied and then rinsed once with filtered sample water. (At Superintendent's Spring, USGS Site ID 362856121103801 and Chalone Bridge Spring, USGS Site ID 362912121101101—disposable 0.45-micron pore capsule filters were used due to excess turbidity).

7. Description of sample transport/preservation: The bottle was sealed in a plastic bag and packed into a cooler, with ice (in order to maintain a temperature of $4^{\circ} \mathrm{C}$ ), for prompt shipment to the NWQL.

8. Lab analytical method/procedure name, source citation, and ID: NWQL Method I-2601-90 Lab Schedule 318; Lab code 3118 , orthophosphate as phosphorus, using colorimetry, DA, phosphomolybdate (Fishman, 1993).
9. Maximum and minimum quantification limits for the method or procedure: This method is used to analyze most samples of water, wastewater, and brines containing from 0.01 to $1.0 \mathrm{mg} / \mathrm{L}$ of orthophosphate-phosphorus.

Concentrations greater than $1.0 \mathrm{mg} / \mathrm{L}$ must be diluted.

10. Method/procedure detection level: At the time of this study, the long-term method detection level (LT-MDL) for total dissolved orthophosphate (as P) was $0.003 \mathrm{mg} / \mathrm{L}$. The reporting level (RL) was $0.006 \mathrm{mg} / \mathrm{L}$.

\section{Phosphorus}

1. Parameter name: Phosphorus (phosphorus as $\mathrm{P}$ )

2. Sample fraction: Phosphorus analyses are performed on filtered water samples.

3. Measurement units: Phosphorus concentrations are reported in milligrams per liter $(\mathrm{mg} / \mathrm{L})$.

4. Field or lab measurement: Measurement of concentrations of phosphorus was conducted at the USGS NWQL in Lakewood, Colorado.

5. Value type: Actual

6. Description of sample preparation procedure: Sample water was syringe filtered through a disposable 0.45 -micron pore disk filter into a $125-\mathrm{mL}$ brown polyethylene bottle. The bottle previously had been lab-rinsed with distilled water and transported to the field half filled with distilled water. In the field, the bottle was emptied and then rinsed once with filtered sample water. (At Superintendent's Spring, USGS Site ID 362856121103801 and Chalone Bridge Spring, USGS Site ID 362912121101101—disposable 0.45-micron pore capsule filters were used due to excess turbidity).

7. Description of sample transport/preservation: The bottle was sealed in a plastic bag and packed into a cooler, with ice (in order to maintain a temperature of $4^{\circ} \mathrm{C}$ ), for prompt shipment to the NWQL.

8. Lab analytical method/procedure name, source citation, and ID: NWQL Method I-2610-99; Lab Schedule 318; Lab code 1983, phosphorus, using colorimetry, automated-segmented flow, Microkjeldahl Digestion (Patton and Truitt, 1992).

9. Maximum and minimum quantification limits for the method or procedure: This method is used to determine total phosphorus in water, wastewater, brines, and water-suspended sediment. The analytical range of this method is 0.01 to $2.00 \mathrm{mg} / \mathrm{L}$ of phosphorus.

10. Method/procedure detection level: At the time of this study, the long-term method detection level (LT-MDL) for phosphorus (as P) was $0.02 \mathrm{mg} / \mathrm{L}$. The reporting Level (RL) was $0.04 \mathrm{mg} / \mathrm{L}$.

\section{Aluminum}

1. Parameter name: Aluminum (aluminum as $\mathrm{Al}$ ).

2. Sample fraction: Aluminum analyses are performed on filtered water samples.

3. Measurement units: Aluminum concentrations are reported in micrograms per liter $(\mu \mathrm{g} / \mathrm{L})$. 
4. Field or lab measurement: Measurement of aluminum concentrations was conducted at the USGS NWQL in Lakewood, Colorado.

5. Value type: Actual.

6. Description of sample preparation procedure: Sample water was syringe filtered through a disposable 0.45 -micron pore disk filter into a 250 -mL polyethylene, acidrinsed bottle. The bottle previously had been lab-rinsed with distilled water and transported to the field half filled with distilled water. In the field, the bottle was emptied and then rinsed once with filtered sample water. (At Superintendent's Spring, USGS Site ID 362856121103801 and Chalone Bridge Spring, USGS Site ID 362912121101101—disposable 0.45-micron pore capsule filters were used due to excess turbidity).

7. Description of sample transport/preservation: After collection, the sample was acidified with nitric acid $\left(\mathrm{HNO}_{3}\right)$ to a $\mathrm{pH}$ of less than 2 . The bottle was sealed in a plastic bag and packed into a cooler, without ice, for shipment to the NWQL.

8. Lab analytical method/procedure name, source citation, and ID: NWQL Method I-247792, Schedule 2710: Trace elements; Lab code 1784: Aluminum, using inductively coupled plasma (ICP), mass spectrometry (MS) (Faires, 1993).

9. Maximum and minimum quantification limits for the method or procedure: The upper calibration limit for aluminum analysis by the ICP-MS method is $2,500 \mu \mathrm{g} / \mathrm{L}$ for samples with specific conductance less than $2,500 \mu \mathrm{S} / \mathrm{cm}$. If the specific conductance of the sample is greater than $2,500 \mu \mathrm{S} / \mathrm{cm}$ the sample must be diluted; however, detection levels and sensitivity will change proportionally.

10. Method/procedure detection level: At the time of this study, the long-term method detection level (LT-MDL) for aluminum was $0.8 \mu \mathrm{g} / \mathrm{L}$. The reporting level (RL) was $1.6 \mu \mathrm{g} / \mathrm{L}$.

\section{Antimony}

1. Parameter name: Antimony (antimony as $\mathrm{Sb}$ ).

2. Sample fraction: Antimony analyses are performed on filtered water samples.

3. Measurement units: Antimony concentrations are reported in micrograms per liter $(\mu \mathrm{g} / \mathrm{L})$.

4. Field or lab measurement: Measurement of antimony concentrations was conducted at the USGS NWQL in Lakewood, Colorado.

5. Value type: Actual.

6. Description of sample preparation procedure: Sample water was syringe filtered through a disposable 0.45 -micron pore disk filter into a $250-\mathrm{mL}$ polyethylene, acidrinsed bottle. The bottle previously had been lab-rinsed with distilled water and transported to the field half filled with distilled water. In the field, the bottle was emptied and then rinsed once with filtered sample water. (At Superintendent's Spring, USGS Site ID 362856121103801 and Chalone Bridge Spring, USGS Site ID 362912121101101—disposable 0.45-micron pore capsule filters were used due to excess turbidity).
7. Description of sample transport/preservation: After collection, the sample was acidified with nitric acid $\left(\mathrm{HNO}_{3}\right)$ to a $\mathrm{pH}$ of less than 2 . The bottle was sealed in a plastic bag and packed into a cooler, without ice, for shipment to the NWQL.

8. Lab analytical method/procedure name, source citation, and ID: NWQL Method I-247792, Schedule 2710: Trace elements; Lab code 1785: Aluminum, using inductively coupled plasma (ICP), mass spectrometry (MS) (Faires, 1993).

9. Maximum and minimum quantification limits for the method or procedure: The upper calibration limit for antimony analysis by the ICP-MS method is $250 \mu \mathrm{g} / \mathrm{L}$ for samples with specific conductance less than $2,500 \mu \mathrm{S} / \mathrm{cm}$. If the specific conductance of the sample is greater than $2,500 \mu \mathrm{S} / \mathrm{cm}$ the sample must be diluted; however, detection levels and sensitivity will change proportionally.

10. Method/procedure detection level: At the time of this study, the long-term method detection level (LT-MDL) for antimony was $0.1 \mu \mathrm{g} / \mathrm{L}$. The reporting level (RL) was $0.2 \mu \mathrm{g} / \mathrm{L}$.

Arsenic

1. Parameter name: Arsenic (arsenic as As).

2. Sample fraction: Arsenic analyses are performed on filtered water samples.

3. Measurement units: Arsenic concentrations are reported in micrograms per liter $(\mu \mathrm{g} / \mathrm{L})$.

4. Field or lab measurement: Measurement of arsenic concentrations was conducted at the USGS NWQL in Lakewood, Colorado.

5. Value type: Actual.

6. Description of sample preparation procedure: Sample water was syringe filtered through a disposable 0.45 -micron pore disk filter into a 250 -mL polyethylene, acidrinsed bottle. The bottle previously had been lab-rinsed with distilled water and transported to the field half filled with distilled water. In the field, the bottle was emptied and then rinsed once with filtered sample water. (At Superintendent's Spring, USGS Site ID 362856121103801 and Chalone Bridge Spring, USGS Site ID 362912121101101—disposable 0.45-micron pore capsule filters were used due to excess turbidity).

7. Description of sample transport/preservation: After collection, the sample was acidified with nitric acid $\left(\mathrm{HNO}_{3}\right)$ to a $\mathrm{pH}$ of less than 2. The bottle was sealed in a plastic bag and packed into a cooler, without ice, for shipment to the NWQL.

8. Lab analytical method/procedure name, source citation, and ID: NWQL Method I-202005, Schedule 2710: Trace elements; Lab code 3122: Arsenic, using collision/reaction cell inductively coupled plasma (ICP), mass spectrometry (MS) (Garbarino and others, 2006).

9. Maximum and minimum quantification limits for the method or procedure: The upper calibration limit for arsenic analysis by the ICP-MS method is $250 \mu \mathrm{g} / \mathrm{L}$ for samples with specific conductance less than $2,500 \mu \mathrm{S} / \mathrm{cm}$. If the specific conductance of the sample is greater than $2,500 \mu \mathrm{S} / \mathrm{cm}$ the sample must be diluted; however, detection levels and sensitivity will change proportionally. 
10. Method/procedure detection level: At the time of this study, the long-term method detection level (LT-MDL) for arsenic was $0.06 \mu \mathrm{g} / \mathrm{L}$. The reporting level (RL) was $0.12 \mu \mathrm{g} / \mathrm{L}$.

\section{Barium}

1. Parameter name: Barium (barium as $\mathrm{Ba}$ ).

2. Sample fraction: Barium analyses are performed on filtered water samples.

3. Measurement units: Barium concentrations are reported in micrograms per liter $(\mu \mathrm{g} / \mathrm{L})$.

4. Field or lab measurement: Measurement of barium concentrations was conducted at the USGS NWQL in Lakewood, Colorado.

5. Value type: Actual.

6. Description of sample preparation procedure: Sample water was syringe filtered through a disposable 0.45 -micron pore disk filter into a $250-\mathrm{mL}$ polyethylene, acidrinsed bottle. The bottle previously had been lab-rinsed with distilled water and transported to the field half filled with distilled water. In the field, the bottle was emptied and then rinsed once with filtered sample water. (At Superintendent's Spring, USGS Site ID 362856121103801 and Chalone Bridge Spring, USGS Site ID 362912121101101—disposable 0.45-micron pore capsule filters were used due to excess turbidity).

7. Description of sample transport/preservation: After collection, the sample was acidified with nitric acid $\left(\mathrm{HNO}_{3}\right)$ to a pH of less than 2. The bottle was sealed in a plastic bag and packed into a cooler, without ice, for shipment to the NWQL.

8. Lab analytical method/procedure name, source citation, and ID: NWQL Method I-247792, Schedule 2710: Trace elements; Lab code 1786: Barium, using inductively coupled plasma (ICP), mass spectrometry (MS) (Faires, 1993).

9. Maximum and minimum quantification limits for the method or procedure: The upper calibration limit for barium analysis by the ICP-MS method is $2,500 \mu \mathrm{g} / \mathrm{L}$ for samples with specific conductance less than $2,500 \mu \mathrm{S} / \mathrm{cm}$. If the specific conductance of the sample is greater than $2,500 \mu \mathrm{S} / \mathrm{cm}$ the sample must be diluted; however, detection levels and sensitivity will change proportionally.

10. Method/procedure detection level: At the time of this study, the long-term method detection level (LT-MDL) for barium was $0.1 \mu \mathrm{g} / \mathrm{L}$. The reporting level (RL) was $0.2 \mu \mathrm{g} / \mathrm{L}$.

\section{Beryllium}

1. Parameter name: Beryllium (beryllium as Be).

2. Sample fraction: Beryllium analyses are performed on filtered water samples.

3. Measurement units: Beryllium concentrations are reported in micrograms per liter $(\mu \mathrm{g} / \mathrm{L})$.

4. Field or lab measurement: Measurement of beryllium concentrations was conducted at the USGS NWQL in Lakewood, Colorado.

5. Value type: Actual.
6. Description of sample preparation procedure: Sample water was syringe filtered through a disposable 0.45 -micron pore disk filter into a $250-\mathrm{mL}$ polyethylene, acidrinsed bottle. The bottle previously had been lab-rinsed with distilled water and transported to the field half filled with distilled water. In the field, the bottle was emptied and then rinsed once with filtered sample water. (At Superintendent's Spring, USGS Site ID 362856121103801 and Chalone Bridge Spring, USGS Site ID 362912121101101—disposable 0.45-micron pore capsule filters were used due to excess turbidity).

7. Description of sample transport/preservation: After collection, the sample was acidified with nitric acid $\left(\mathrm{HNO}_{3}\right)$ to a pH of less than 2. The bottle was sealed in a plastic bag and packed into a cooler, without ice, for shipment to the NWQL.

8. Lab analytical method/procedure name, source citation, and ID: NWQL Method I-247792, Schedule 2710: Trace elements; Lab code 1787: Beryllium, using inductively coupled plasma (ICP), mass spectrometry (MS) (Faires, 1993).

9. Maximum and minimum quantification limits for the method or procedure: The upper calibration limit for beryllium analysis by the ICP-MS method is $250 \mu \mathrm{g} / \mathrm{L}$ for samples with specific conductance less than $2,500 \mu \mathrm{S} / \mathrm{cm}$. If the specific conductance of the sample is greater than $2,500 \mu \mathrm{S} / \mathrm{cm}$ the sample must be diluted; however, detection levels and sensitivity will change proportionally.

10. Method/procedure detection level: At the time of this study, the long-term method detection level (LT-MDL) for beryllium was $0.03 \mu \mathrm{g} / \mathrm{L}$. The reporting level (RL) was $0.06 \mu \mathrm{g} / \mathrm{L}$.

\section{Boron}

1. Parameter name: Boron (boron as B).

2. Sample fraction: Boron analyses are performed on filtered water samples.

3. Measurement units: Boron concentrations are reported in micrograms per liter $(\mu \mathrm{g} / \mathrm{L})$.

4. Field or lab measurement: Measurement of boron concentrations was conducted at the USGS NWQL in Lakewood, Colorado.

5. Value type: Actual.

6. Description of sample preparation procedure:

Sample water was syringe filtered through a disposable 0.45 -micron pore disk filter into a $250-\mathrm{mL}$ polyethylene, acidrinsed bottle. The bottle previously had been lab-rinsed with distilled water and transported to the field half filled with distilled water. In the field, the bottle was emptied and then rinsed once with filtered sample water. (At Superintendent's Spring, USGS Site ID 362856121103801 and Chalone Bridge Spring, USGS Site ID 362912121101101—disposable 0.45-micron pore capsule filters were used due to excess turbidity).

7. Description of sample transport/preservation: After collection, the sample was acidified with nitric acid $\left(\mathrm{HNO}_{3}\right)$ to a pH of less than 2. The bottle was sealed in a plastic bag and packed into a cooler, without ice, for shipment to the NWQL. 
8. Lab analytical method/procedure name, source citation, and ID: NWQL Method I-247792, Schedule 2710: Trace elements; Lab code 2504: Boron, using inductively coupled plasma (ICP), mass spectrometry (MS) (Garbarino, 1999).

9. Maximum and minimum quantification limits for the method or procedure: The upper calibration limit for boron analysis by the ICP-MS method is $1,000 \mu \mathrm{g} / \mathrm{L}$ for samples with specific conductance less than $2,500 \mu \mathrm{S} / \mathrm{cm}$. If the specific conductance of the sample is greater than $2,500 \mu \mathrm{S} / \mathrm{cm}$ the sample must be diluted; however, detection levels and sensitivity will change proportionally.

10. Method/procedure detection level: At the time of this study, the long-term method detection level (LT-MDL) for boron was $4 \mu \mathrm{g} / \mathrm{L}$. The reporting level (RL) was $8 \mu \mathrm{g} / \mathrm{L}$.

\section{Cadmium}

1. Parameter name: Cadmium (cadmium as $\mathrm{Cd}$ ).

2. Sample fraction: Cadmium analyses are performed on filtered water samples.

3. Measurement units: Cadmium concentrations are reported in micrograms per liter $(\mu \mathrm{g} / \mathrm{L})$.

4. Field or lab measurement: Measurement of cadmium concentrations was conducted at the USGS NWQL in Lakewood, Colorado.

5. Value type: Actual.

6. Description of sample preparation procedure:

Sample water was syringe filtered through a disposable 0.45 -micron pore disk filter into a 250 -mL polyethylene, acidrinsed bottle. The bottle previously had been lab-rinsed with distilled water and transported to the field half filled with distilled water. In the field, the bottle was emptied and then rinsed once with filtered sample water. (At Superintendent's Spring, USGS Site ID 362856121103801 and Chalone Bridge Spring, USGS Site ID 362912121101101—disposable 0.45-micron pore capsule filters were used due to excess turbidity).

7. Description of sample transport/preservation: After collection, the sample was acidified with nitric acid $\left(\mathrm{HNO}_{3}\right)$ to a $\mathrm{pH}$ of less than 2 . The bottle was sealed in a plastic bag and packed into a cooler, without ice, for shipment to the NWQL.

8. Lab analytical method/procedure name, source citation, and ID: NWQL Method I-247792, Schedule 2710: Trace elements; Lab code 1788: Cadmium, using inductively coupled plasma (ICP), mass spectrometry (MS) (Faires, 1993).

9. Maximum and minimum quantification limits for the method or procedure: The upper calibration limit for cadmium analysis by the ICP-MS method is $250 \mu \mathrm{g} / \mathrm{L}$ for samples with specific conductance less than $2,500 \mu \mathrm{S} / \mathrm{cm}$. If the specific conductance of the sample is greater than $2,500 \mu \mathrm{S} / \mathrm{cm}$ the sample must be diluted; however, detection levels and sensitivity will change proportionally.

10. Method/procedure detection level: At the time of this study, the long-term method detection level (LT-MDL) for cadmium was $0.02 \mu \mathrm{g} / \mathrm{L}$. The reporting level (RL) was $0.04 \mu \mathrm{g} / \mathrm{L}$.

\section{Chromium}

1. Parameter name: Chromium (chromium as $\mathrm{Cr}$ ).

2. Sample fraction: Chromium analyses are performed on filtered water samples.

3. Measurement units: Chromium concentrations are reported in micrograms per liter $(\mu \mathrm{g} / \mathrm{L})$.

4. Field or lab measurement: Measurement of chromium concentrations was conducted at the USGS NWQL in Lakewood, Colorado.

5. Value type: Actual.

6. Description of sample preparation procedure: Sample water was syringe filtered through a disposable 0.45 -micron pore disk filter into a $250-\mathrm{mL}$ polyethylene, acidrinsed bottle. The bottle previously had been lab-rinsed with distilled water and transported to the field half filled with distilled water. In the field, the bottle was emptied and then rinsed once with filtered sample water. (At Superintendent's Spring, USGS Site ID 362856121103801 and Chalone Bridge Spring, USGS Site ID 362912121101101—disposable 0.45-micron pore capsule filters were used due to excess turbidity).

7. Description of sample transport/preservation: After collection, the sample was acidified with nitric acid $\left(\mathrm{HNO}_{3}\right)$ to a $\mathrm{pH}$ of less than 2 . The bottle was sealed in a plastic bag and packed into a cooler, without ice, for shipment to the NWQL.

8. Lab analytical method/procedure name, source citation, and ID: NWQL Method I-202005, Schedule 2710: Trace elements; Lab code 3126: Chromium, using collision/reaction cell inductively coupled plasma (ICP), mass spectrometry (MS) (Garbarino and others, 2006).

9. Maximum and minimum quantification limits for the method or procedure: The upper calibration limit for chromium analysis by the ICP-MS method is $100 \mu \mathrm{g} / \mathrm{L}$ for samples with specific conductance less than $2,500 \mu \mathrm{S} / \mathrm{cm}$. If the specific conductance of the sample is greater than $2,500 \mu \mathrm{S} / \mathrm{cm}$ the sample must be diluted; however, detection levels and sensitivity will change proportionally.

10. Method/procedure detection level: At the time of this study, the long-term method detection level (LT-MDL) for chromium was $0.02 \mu \mathrm{g} / \mathrm{L}$. The reporting level (RL) was $0.04 \mu \mathrm{g} / \mathrm{L}$.

Cobalt

1. Parameter name: Cobalt (cobalt as $\mathrm{Co}$ ).

2. Sample fraction: Cobalt analyses are performed on filtered water samples.

3. Measurement units: Cobalt concentrations are reported in micrograms per liter $(\mu \mathrm{g} / \mathrm{L})$.

4. Field or lab measurement: Measurement of cobalt concentrations was conducted at the USGS NWQL in Lakewood, Colorado.

\section{Value type: Actual.}

6. Description of sample preparation procedure:

Sample water was syringe filtered through a disposable 0.45 -micron pore disk filter into a $250-\mathrm{mL}$ polyethylene, acidrinsed bottle. The bottle previously had been lab-rinsed with distilled water and transported to the field half filled with 
distilled water. In the field, the bottle was emptied and then rinsed once with filtered sample water. (At Superintendent's Spring, USGS Site ID 362856121103801 and Chalone Bridge Spring, USGS Site ID 362912121101101—disposable 0.45micron pore capsule filters were used due to excess turbidity).

7. Description of sample transport/preservation: After collection, the sample was acidified with nitric acid $\left(\mathrm{HNO}_{3}\right)$ to a $\mathrm{pH}$ of less than 2 . The bottle was sealed in a plastic bag and packed into a cooler, without ice, for shipment to the NWQL.

8. Lab analytical method/procedure name, source citation, and ID: NWQL Method I-202005, Schedule 2710: Trace elements; Lab code 3124: Cobalt, using collision/reaction cell inductively coupled plasma (ICP), mass spectrometry (MS) (Garbarino and others, 2006).

9. Maximum and minimum quantification limits for the method or procedure: The upper calibration limit for cobalt analysis by the ICP-MS method is $100 \mu \mathrm{g} / \mathrm{L}$ for samples with specific conductance less than $2,500 \mu \mathrm{S} / \mathrm{cm}$. If the specific conductance of the sample is greater than $2,500 \mu \mathrm{S} / \mathrm{cm}$ the sample must be diluted; however, detection levels and sensitivity will change proportionally.

10. Method/procedure detection level: At the time of this study, the long-term method detection level (LT-MDL) for cobalt was $0.02 \mu \mathrm{g} / \mathrm{L}$. The reporting level (RL) was $0.04 \mu \mathrm{g} / \mathrm{L}$.

\section{Copper}

1. Parameter name: Copper (copper as $\mathrm{Cu}$ ).

2. Sample fraction: Copper analyses are performed on filtered water samples.

3. Measurement units: Copper concentrations are reported in micrograms per liter $(\mu \mathrm{g} / \mathrm{L})$.

4. Field or lab measurement: Measurement of copper concentrations was conducted at the USGS NWQL in Lakewood, Colorado.

5. Value type: Actual.

6. Description of sample preparation procedure: Sample water was syringe filtered through a disposable 0.45 -micron pore disk filter into a $250-\mathrm{mL}$ polyethylene, acidrinsed bottle. The bottle previously had been lab-rinsed with distilled water and transported to the field half filled with distilled water. In the field, the bottle was emptied and then rinsed once with filtered sample water. (At Superintendent's Spring, USGS Site ID 362856121103801 and Chalone Bridge Spring, USGS Site ID 362912121101101—disposable 0.45-micron pore capsule filters were used due to excess turbidity).

7. Description of sample transport/preservation: After collection, the sample was acidified with nitric acid $\left(\mathrm{HNO}_{3}\right)$ to a $\mathrm{pH}$ of less than 2 . The bottle was sealed in a plastic bag and packed into a cooler, without ice, for shipment to the NWQL.

8. Lab analytical method/procedure name, source citation, and ID: NWQL Method I-202005, Schedule 2710: Trace elements; Lab code 3128: Copper, using collision/reaction cell inductively coupled plasma (ICP), mass spectrometry (MS) (Garbarino and others, 2006).

9. Maximum and minimum quantification limits for the method or procedure: The upper calibration limit for copper analysis by the ICP-MS method is $250 \mu \mathrm{g} / \mathrm{L}$ for samples with specific conductance less than $2,500 \mu \mathrm{S} / \mathrm{cm}$. If the specific conductance of the sample is greater than $2,500 \mu \mathrm{S} / \mathrm{cm}$ the sample must be diluted; however, detection levels and sensitivity will change proportionally.

10. Method/procedure detection level: At the time of this study, the long-term method detection level (LT-MDL) for copper was $0.02 \mu \mathrm{g} / \mathrm{L}$. The reporting level (RL) was $0.04 \mu \mathrm{g} / \mathrm{L}$.

\section{Iron}

1. Parameter name: Iron (iron as $\mathrm{Fe}$ ).

2. Sample fraction: Iron analyses are performed on filtered water samples.

3. Measurement units: Iron concentrations are reported in micrograms per liter $(\mu \mathrm{g} / \mathrm{L})$.

4. Field or lab measurement: Measurement of iron concentrations was conducted at the USGS NWQL in Lakewood, Colorado.

5. Value type: Actual.

6. Description of sample preparation procedure: Sample water was syringe filtered through a disposable 0.45 -micron pore disk filter into a 250 - $\mathrm{mL}$ polyethylene, acidrinsed bottle. The bottle previously had been lab-rinsed with distilled water and transported to the field half filled with distilled water. In the field, the bottle was emptied and then rinsed once with filtered sample water. (At Superintendent's Spring, USGS Site ID 362856121103801 and Chalone Bridge Spring, USGS Site ID 362912121101101—disposable 0.45-micron pore capsule filters were used due to excess turbidity).

7. Description of sample transport/preservation: After collection, the sample was acidified with nitric acid $\left(\mathrm{HNO}_{3}\right)$ to a $\mathrm{pH}$ of less than 2 . The bottle was sealed in a plastic bag and packed into a cooler, without ice, for shipment to the NWQL.

8. Lab analytical method/procedure name, source citation, and ID: NWQL Method I-147287, Lab Schedule 2750, Lab code 645: Iron, using inductively coupled plasma (ICP), atomic emission spectrometry (Fishman, 1993).

9. Maximum and minimum quantification limits for the method or procedure: This method may be used to analyze water containing from 5 to $10,000 \mu \mathrm{g} / \mathrm{L}$ of iron for water that has a measured specific conductance of less than $2,000 \mu \mathrm{S} / \mathrm{cm}$. Iron also can be determined after appropriate dilution in samples that have a measured specific conductance greater than 2,000 $\mu \mathrm{S} / \mathrm{cm}$; however, detection levels and sensitivity will change proportionally.

10. Method/procedure detection level: At the time of this study, the long-term method detection level (LT-MDL) for iron was $3 \mu \mathrm{g} / \mathrm{L}$. The reporting level (RL) was $6 \mu \mathrm{g} / \mathrm{L}$.

\section{Lead}

1. Parameter name: Lead (lead as $\mathrm{Pb}$ ).

2. Sample fraction: Lead analyses are performed on filtered water samples.

3. Measurement units: Lead concentrations are reported in micrograms per liter $(\mu \mathrm{g} / \mathrm{L})$. 
4. Field or lab measurement: Measurement of lead concentrations was conducted at the USGS NWQL in Lakewood, Colorado.

5. Value type: Actual.

6. Description of sample preparation procedure: Sample water was syringe filtered through a disposable 0.45 -micron pore disk filter into a 250 -mL polyethylene, acidrinsed bottle. The bottle previously had been lab-rinsed with distilled water and transported to the field half filled with distilled water. In the field, the bottle was emptied and then rinsed once with filtered sample water. (At Superintendent's Spring, USGS Site ID 362856121103801 and Chalone Bridge Spring, USGS Site ID 362912121101101—disposable 0.45-micron pore capsule filters were used due to excess turbidity).

7. Description of sample transport/preservation: After collection, the sample was acidified with nitric acid $\left(\mathrm{HNO}_{3}\right)$ to a $\mathrm{pH}$ of less than 2 . The bottle was sealed in a plastic bag and packed into a cooler, without ice, for shipment to the NWQL.

8. Lab analytical method/procedure name, source citation, and ID: NWQL Method I-247792, Schedule 2710: Trace elements; Lab code 1792: Lead, using inductively coupled plasma (ICP), mass spectrometry (MS) (Faires, 1993).

9. Maximum and minimum quantification limits for the method or procedure: The upper calibration limit for lead analysis by the ICP-MS method is $250 \mu \mathrm{g} / \mathrm{L}$ for samples with specific conductance less than $2,500 \mu \mathrm{S} / \mathrm{cm}$. If the specific conductance of the sample is greater than $2,500 \mu \mathrm{S} / \mathrm{cm}$ the sample must be diluted; however, detection levels and sensitivity will change proportionally.

10. Method/procedure detection level: At the time of this study, the long-term method detection level (LT-MDL) for lead was $0.04 \mu \mathrm{g} / \mathrm{L}$. The reporting level (RL) was $0.08 \mu \mathrm{g} / \mathrm{L}$.

\section{Lithium}

1. Parameter name: Lithium (lithium as Li).

2. Sample fraction: Lithium analyses are performed on filtered water samples.

3. Measurement units: Lithium concentrations are reported in micrograms per liter $(\mu \mathrm{g} / \mathrm{L})$.

4. Field or lab measurement: Measurement of lithium concentrations was conducted at the USGS NWQL in Lakewood, Colorado.

5. Value type: Actual.

6. Description of sample preparation procedure: Sample water was syringe filtered through a disposable 0.45 -micron pore disk filter into a 250 -mL polyethylene, acidrinsed bottle. The bottle previously had been lab-rinsed with distilled water and transported to the field half filled with distilled water. In the field, the bottle was emptied and then rinsed once with filtered sample water. (At Superintendent's Spring, USGS Site ID 362856121103801 and Chalone Bridge Spring, USGS Site ID 362912121101101—disposable 0.45-micron pore capsule filters were used due to excess turbidity).

7. Description of sample transport/preservation: After collection, the sample was acidified with nitric acid $\left(\mathrm{HNO}_{3}\right)$ to a $\mathrm{pH}$ of less than 2. The bottle was sealed in a plastic bag and packed into a cooler, without ice, for shipment to the NWQL.

8. Lab analytical method/procedure name, source citation, and ID: NWQL Method I-247792, Schedule 2710: Trace elements; Lab code 2505: Lithium, using inductively coupled plasma (ICP), mass spectrometry (MS) (Faires, 1993).

9. Maximum and minimum quantification limits for the method or procedure: The upper calibration limit for lithium analysis by the ICP-MS method is $250 \mu \mathrm{g} / \mathrm{L}$ for samples with specific conductance less than $2,500 \mu \mathrm{S} / \mathrm{cm}$. If the specific conductance of the sample is greater than $2,500 \mu \mathrm{S} / \mathrm{cm}$ the sample must be diluted; however, detection levels and sensitivity will change proportionally.

10. Method/procedure detection level: At the time of this study, the long-term method detection level (LT-MDL) for lithium was $0.3 \mu \mathrm{g} / \mathrm{L}$. The reporting level (RL) was $0.6 \mu \mathrm{g} / \mathrm{L}$.

\section{Manganese}

1. Parameter name: Manganese (manganese as Mn).

2. Sample fraction: Manganese analyses are performed on filtered water samples.

3. Measurement units: Manganese concentrations are reported in micrograms per liter $(\mu \mathrm{g} / \mathrm{L})$.

4. Field or lab measurement: Measurement of manganese concentrations was conducted at the USGS NWQL in Lakewood, Colorado.

5. Value type: Actual.

6. Description of sample preparation procedure: Sample water was syringe filtered through a disposable 0.45 -micron pore disk filter into a 250 - $\mathrm{mL}$ polyethylene, acidrinsed bottle. The bottle previously had been lab-rinsed with distilled water and transported to the field half filled with distilled water. In the field, the bottle was emptied and then rinsed once with filtered sample water. (At Superintendent's Spring, USGS Site ID 362856121103801 and Chalone Bridge Spring, USGS Site ID 362912121101101—disposable 0.45-micron pore capsule filters were used due to excess turbidity).

7. Description of sample transport/preservation: After collection, the sample was acidified with nitric acid $\left(\mathrm{HNO}_{3}\right)$ to a $\mathrm{pH}$ of less than 2. The bottle was sealed in a plastic bag and packed into a cooler, without ice, for shipment to the NWQL.

8. Lab analytical method/procedure name, source citation, and ID: NWQL Method I-247792, Schedule 2710: Trace elements; Lab code 1793: Manganese, using inductively coupled plasma (ICP), mass spectrometry (MS) (Faires, 1993).

9. Maximum and minimum quantification limits for the method or procedure: The upper calibration limit for manganese analysis by the ICP-MS method is $2,500 \mu \mathrm{g} / \mathrm{L}$ for samples with specific conductance less than $2,500 \mu \mathrm{S} / \mathrm{cm}$. If the specific conductance of the sample is greater than 2,500 $\mu \mathrm{S} / \mathrm{cm}$ the sample must be diluted; however, detection levels and sensitivity will change proportionally.

10. Method/procedure detection level: At the time of this study, the long-term method detection level (LT-MDL) for manganese was $0.1 \mu \mathrm{g} / \mathrm{L}$. The reporting level (RL) was $0.2 \mu \mathrm{g} / \mathrm{L}$. 


\section{Molybdenum}

1. Parameter name: Molybdenum (molybdenum as Mo).

2. Sample fraction: Molybdenum analyses are per-

formed on filtered water samples.

3. Measurement units: Molybdenum concentrations are reported in micrograms per liter $(\mu \mathrm{g} / \mathrm{L})$.

4. Field or lab measurement: Measurement of molybdenum concentrations was conducted at the USGS NWQL in Lakewood, Colorado.

5. Value type: Actual.

6. Description of sample preparation procedure: Sample water was syringe filtered through a disposable 0.45-micron pore disk filter into a 250 - $\mathrm{mL}$ polyethylene, acidrinsed bottle. The bottle previously had been lab-rinsed with distilled water and transported to the field half filled with distilled water. In the field, the bottle was emptied and then rinsed once with filtered sample water. (At Superintendent's Spring, USGS Site ID 362856121103801 and Chalone Bridge Spring, USGS Site ID 362912121101101-disposable 0.45-micron pore capsule filters were used due to excess turbidity).

7. Description of sample transport/preservation: After collection, the sample was acidified with nitric acid $\left(\mathrm{HNO}_{3}\right)$ to a pH of less than 2 . The bottle was sealed in a plastic bag and packed into a cooler, without ice, for shipment to the NWQL.

8. Lab analytical method/procedure name, source citation, and ID: NWQL Method I-247792, Schedule 2710: Trace elements; Lab code 1794: Molybdenum, using inductively coupled plasma (ICP), mass spectrometry (MS) (Faires, 1993).

9. Maximum and minimum quantification limits for the method or procedure: The upper calibration limit for molybdenum analysis by the ICP-MS method is $250 \mu \mathrm{g} / \mathrm{L}$ for samples with specific conductance less than $2,500 \mu \mathrm{S} /$ $\mathrm{cm}$. If the specific conductance of the sample is greater than $2,500 \mu \mathrm{S} / \mathrm{cm}$, the sample must be diluted; however, detection levels and sensitivity will change proportionally.

10. Method/procedure detection level: At the time of this study, the long-term method detection level (LT-MDL) for molybdenum was $0.2 \mu \mathrm{g} / \mathrm{L}$. The reporting level (RL) was $0.4 \mu \mathrm{g} / \mathrm{L}$.

\section{Nickel}

1. Parameter name: Nickel (nickel as $\mathrm{Ni}$ ).

2. Sample fraction: Nickel analyses are performed on filtered water samples.

3. Measurement units: Nickel concentrations are reported in micrograms per liter $(\mu \mathrm{g} / \mathrm{L})$.

4. Field or lab measurement: Measurement of nickel concentrations was conducted at the USGS NWQL in Lakewood, Colorado.

5. Value type: Actual.

6. Description of sample preparation procedure: Sample water was syringe filtered through a disposable 0.45 -micron pore disk filter into a 250 -mL polyethylene, acidrinsed bottle. The bottle previously had been lab-rinsed with distilled water and transported to the field half filled with distilled water. In the field, the bottle was emptied and then rinsed once with filtered sample water. (At Superintendent's Spring, USGS Site ID 362856121103801 and Chalone Bridge Spring, USGS Site ID 362912121101101—disposable 0.45micron pore capsule filters were used due to excess turbidity).

7. Description of sample transport/preservation: After collection, the sample was acidified with nitric acid $\left(\mathrm{HNO}_{3}\right)$ to a pH of less than 2. The bottle was sealed in a plastic bag and packed into a cooler, without ice, for shipment to the NWQL.

8. Lab analytical method/procedure name, source citation, and ID: NWQL Method I-202005, Schedule 2710: Trace elements; Lab code 3130: Nickel, using collision/reaction cell inductively coupled plasma (ICP), mass spectrometry (MS) (Garbarino and others, 2006).

9. Maximum and minimum quantification limits for the method or procedure: The upper calibration limit for nickel analysis by the ICP-MS method is $100 \mu \mathrm{g} / \mathrm{L}$ for samples with specific conductance less than $2,500 \mu \mathrm{S} / \mathrm{cm}$. If the specific conductance of the sample is greater than $2,500 \mu \mathrm{S} / \mathrm{cm}$, the sample must be diluted; however, detection levels and sensitivity will change proportionally.

10. Method/procedure detection level: At the time of this study, the long-term method detection level (LT-MDL) for nickel was $0.03 \mu \mathrm{g} / \mathrm{L}$. The reporting level (RL) was $0.06 \mu \mathrm{g} / \mathrm{L}$.

\section{Selenium}

1. Parameter name: Selenium (selenium as Se).

2. Sample fraction: Selenium analyses are performed on filtered water samples.

3. Measurement units: Selenium concentrations are reported in micrograms per liter $(\mu \mathrm{g} / \mathrm{L})$.

4. Field or lab measurement: Measurement of selenium concentrations was conducted at the USGS NWQL in Lakewood, Colorado.

5. Value type: Actual.

6. Description of sample preparation procedure:

Sample water was syringe filtered through a disposable 0.45 -micron pore disk filter into a $250-\mathrm{mL}$ polyethylene, acidrinsed bottle. The bottle previously had been lab-rinsed with distilled water and transported to the field half filled with distilled water. In the field, the bottle was emptied and then rinsed once with filtered sample water. (At Superintendent's Spring, USGS Site ID 362856121103801 and Chalone Bridge Spring, USGS Site ID 362912121101101—disposable 0.45-micron pore capsule filters were used due to excess turbidity).

7. Description of sample transport/preservation: After collection, the sample was acidified with nitric acid $\left(\mathrm{HNO}_{3}\right)$ to a pH of less than 2. The bottle was sealed in a plastic bag and packed into a cooler, without ice, for shipment to the NWQL.

8. Lab analytical method/procedure name, source citation, and ID: NWQL Method I-202005, Schedule 2710: Trace elements; Lab code 3132: Selenium, using collision/reaction cell inductively coupled plasma (ICP), mass spectrometry (MS) (Garbarino and others, 2006). 
9. Maximum and minimum quantification limits for the method or procedure: The upper calibration limit for selenium analysis by the ICP-MS method is $250 \mu \mathrm{g} / \mathrm{L}$ for samples with specific conductance less than $2,500 \mu \mathrm{S} / \mathrm{cm}$. If the specific conductance of the sample is greater than $2,500 \mu \mathrm{S} / \mathrm{cm}$ the sample must be diluted; however, detection levels and sensitivity will change proportionally.

10. Method/procedure detection level: At the time of this study, the long-term method detection level (LT-MDL) for selenium was $0.04 \mu \mathrm{g} / \mathrm{L}$. The reporting level (RL) was $0.08 \mu \mathrm{g} / \mathrm{L}$.

\section{Silver}

1. Parameter name: Silver (silver as Ag).

2. Sample fraction: Silver analyses are performed on filtered water samples.

3. Measurement units: Silver concentrations are reported in micrograms per liter $(\mu \mathrm{g} / \mathrm{L})$.

4. Field or lab measurement: Measurement of silver concentrations was conducted at the USGS NWQL in Lakewood, Colorado.

5. Value type: Actual.

6. Description of sample preparation procedure: Sample water was syringe filtered through a disposable 0.45-micron pore disk filter into a 250 -mL polyethylene, acidrinsed bottle. The bottle previously had been lab-rinsed with distilled water and transported to the field half filled with distilled water. In the field, the bottle was emptied and then rinsed once with filtered sample water. (At Superintendent's Spring, USGS Site ID 362856121103801 and Chalone Bridge Spring, USGS Site ID 362912121101101—disposable 0.45-micron pore capsule filters were used due to excess turbidity).

7. Description of sample transport/preservation: After collection, the sample was acidified with nitric acid $\left(\mathrm{HNO}_{3}\right)$ to a $\mathrm{pH}$ of less than 2 . The bottle was sealed in a plastic bag and packed into a cooler, without ice, for shipment to the NWQL.

8. Lab analytical method/procedure name, source citation, and ID: NWQL Method I-247792, Schedule 2710: Trace elements; Lab code 1796: Silver, using inductively coupled plasma (ICP), mass spectrometry (MS) (Faires, 1993).

9. Maximum and minimum quantification limits for the method or procedure: The upper calibration limit for silver analysis by the ICP-MS method is $250 \mu \mathrm{g} / \mathrm{L}$ for samples with specific conductance less than $2,500 \mu \mathrm{S} / \mathrm{cm}$. If the specific conductance of the sample is greater than $2,500 \mu \mathrm{S} / \mathrm{cm}$ the sample must be diluted; however, detection levels and sensitivity will change proportionally.

10. Method/procedure detection level: At the time of this study, the long-term method detection level (LT-MDL) for silver was $0.1 \mu \mathrm{g} / \mathrm{L}$. The reporting level (RL) was $0.20 \mu \mathrm{g} / \mathrm{L}$.

\section{Strontium}

1. Parameter name: Strontium (strontium as $\mathrm{Sr}$ ).

2. Sample fraction: Strontium analyses are performed on filtered water samples.
3. Measurement units: Strontium concentrations are reported in micrograms per liter $(\mu \mathrm{g} / \mathrm{L})$.

4. Field or lab measurement: Measurement of strontium concentrations was conducted at the USGS NWQL in Lakewood, Colorado.

5. Value type: Actual.

6. Description of sample preparation procedure: Sample water was syringe filtered through a disposable 0.45 -micron pore disk filter into a 250 -mL polyethylene, acidrinsed bottle. The bottle previously had been lab-rinsed with distilled water and transported to the field half filled with distilled water. In the field, the bottle was emptied and then rinsed once with filtered sample water. (At Superintendent's Spring, USGS Site ID 362856121103801 and Chalone Bridge Spring, USGS Site ID 362912121101101—disposable 0.45-micron pore capsule filters were used due to excess turbidity).

7. Description of sample transport/preservation: After collection, the sample was acidified with nitric acid $\left(\mathrm{HNO}_{3}\right)$ to a $\mathrm{pH}$ of less than 2. The bottle was sealed in a plastic bag and packed into a cooler, without ice, for shipment to the NWQL.

8. Lab analytical method/procedure name, source citation, and ID: NWQL Method I-247792, Schedule 2710: Trace elements; Lab code 2507: Strontium, using inductively coupled plasma (ICP), mass spectrometry (MS) (Garbarino, 1999).

9. Maximum and minimum quantification limits for the method or procedure: The upper calibration limit for strontium analysis by the ICP-MS method is $2,500 \mu \mathrm{g} / \mathrm{L}$ for samples with specific conductance less than $2,500 \mu \mathrm{S} / \mathrm{cm}$. If the specific conductance of the sample is greater than $2,500 \mu \mathrm{S} / \mathrm{cm}$, the sample must be diluted; however, detection levels and sensitivity will change proportionally.

10. Method/procedure detection level: At the time of this study, the long-term method detection level (LT-MDL) for strontium was $0.2 \mu \mathrm{g} / \mathrm{L}$. The reporting level (RL) was $0.4 \mu \mathrm{g} / \mathrm{L}$.

\section{Thallium}

1. Parameter name: Thallium (thallium as $\mathrm{Tl}$ ).

2. Sample fraction: Thallium analyses are performed on filtered water samples.

3. Measurement units: Thallium concentrations are reported in micrograms per liter $(\mu \mathrm{g} / \mathrm{L})$.

4. Field or lab measurement: Measurement of thallium concentrations was conducted at the USGS NWQL in Lakewood, Colorado.

5. Value type: Actual.

6. Description of sample preparation procedure:

Sample water was syringe filtered through a disposable 0.45 -micron pore disk filter into a $250-\mathrm{mL}$ polyethylene, acidrinsed bottle. The bottle previously had been lab-rinsed with distilled water and transported to the field half filled with distilled water. In the field, the bottle was emptied and then rinsed once with filtered sample water. (At Superintendent's Spring, USGS Site ID 362856121103801 and Chalone Bridge Spring, USGS Site ID 362912121101101-disposable 0.45-micron pore capsule filters were used due to excess turbidity). 
7. Description of sample transport/preservation: After collection, the sample was acidified with nitric acid $\left(\mathrm{HNO}_{3}\right)$ to a pH of less than 2 . The bottle was sealed in a plastic bag and packed into a cooler, without ice, for shipment to the NWQL.

8. Lab analytical method/procedure name, source citation, and ID: NWQL Method I-247792, Schedule 2710: Trace elements; Lab code 2508: Thallium, using inductively coupled plasma (ICP), mass spectrometry (MS) (Garbarino, 1999).

9. Maximum and minimum quantification limits for the method or procedure: The upper calibration limit for thallium analysis by the ICP-MS method is $250 \mu \mathrm{g} / \mathrm{L}$ for samples with specific conductance less than $2,500 \mu \mathrm{S} / \mathrm{cm}$. If the specific conductance of the sample is greater than $2,500 \mu \mathrm{S} / \mathrm{cm}$, the sample must be diluted; however, detection levels and sensitivity will change proportionally.

10. Method/procedure detection level: At the time of this study, the long-term method detection level (LT-MDL) for thallium was $0.02 \mu \mathrm{g} / \mathrm{L}$. The reporting level (RL) was $0.04 \mu \mathrm{g} / \mathrm{L}$.

\section{Uranium, natural}

1. Parameter name: Uranium, natural (uranium as U).

2. Sample fraction: Uranium analyses are performed on filtered water samples.

3. Measurement units: Uranium concentrations are reported in micrograms per liter $(\mu \mathrm{g} / \mathrm{L})$.

4. Field or lab measurement: Measurement of uranium concentrations was conducted at the USGS NWQL in Lakewood, Colorado.

5. Value type: Actual.

6. Description of sample preparation procedure: Sample water was syringe filtered through a disposable 0.45 -micron pore disk filter into a 250 - $\mathrm{mL}$ polyethylene, acidrinsed bottle. The bottle previously had been lab-rinsed with distilled water and transported to the field half filled with distilled water. In the field, the bottle was emptied and then rinsed once with filtered sample water. (At Superintendent's Spring, USGS Site ID 362856121103801 and Chalone Bridge Spring, USGS Site ID 362912121101101—disposable 0.45-micron pore capsule filters were used due to excess turbidity).

7. Description of sample transport/preservation: After collection, the sample was acidified with nitric acid $\left(\mathrm{HNO}_{3}\right)$ to a pH of less than 2. The bottle was sealed in a plastic bag and packed into a cooler, without ice, for shipment to the NWQL.

8. Lab analytical method/procedure name, source citation, and ID: NWQL Method I-247792, Schedule 2710: Trace elements; Lab code 1797: Uranium, using inductively coupled plasma (ICP), mass spectrometry (MS) (Faires, 1993).

9. Maximum and minimum quantification limits for the method or procedure: The upper calibration limit for uranium analysis by the ICP-MS method is $250 \mu \mathrm{g} / \mathrm{L}$ for samples with specific conductance less than $2,500 \mu \mathrm{S} / \mathrm{cm}$. If the specific conductance of the sample is greater than $2,500 \mu \mathrm{S} / \mathrm{cm}$ the sample must be diluted; however, detection levels and sensitivity will change proportionally.
10. Method/procedure detection level: At the time of this study, the long-term method detection level (LT-MDL) for uranium was $0.02 \mu \mathrm{g} / \mathrm{L}$. The reporting level (RL) was $0.04 \mu \mathrm{g} / \mathrm{L}$.

\section{Vanadium}

1. Parameter name: Vanadium (vanadium as V).

2. Sample fraction: Vanadium analyses are performed on filtered water samples.

3. Measurement units: Vanadium concentrations are reported in micrograms per liter $(\mu \mathrm{g} / \mathrm{L})$.

4. Field or lab measurement: Measurement of vanadium concentrations was conducted at the USGS NWQL in Lakewood, Colorado.

5. Value type: Actual.

6. Description of sample preparation procedure: Sample water was syringe filtered through a disposable 0.45 -micron pore disk filter into a $250-\mathrm{mL}$ polyethylene, acidrinsed bottle. The bottle previously had been lab-rinsed with distilled water and transported to the field half filled with distilled water. In the field, the bottle was emptied and then rinsed once with filtered sample water. (At Superintendent's Spring, USGS Site ID 362856121103801 and Chalone Bridge Spring, USGS Site ID 362912121101101—disposable 0.45-micron pore capsule filters were used due to excess turbidity).

7. Description of sample transport/preservation: After collection, the sample was acidified with nitric acid $\left(\mathrm{HNO}_{3}\right)$ to a pH of less than 2. The bottle was sealed in a plastic bag and packed into a cooler, without ice, for shipment to the NWQL.

8. Lab analytical method/procedure name, source citation, and ID: NWQL Method I-202005, Schedule 2710: Trace elements; Lab code 3134: vanadium, using collision/reaction cell inductively coupled plasma (ICP), mass spectrometry (MS) (Garbarino and others, 2006).

9. Maximum and minimum quantification limits for the method or procedure: The upper calibration limit for vanadium analysis by the ICP-MS method is $100 \mu \mathrm{g} / \mathrm{L}$ for samples with specific conductance less than $2,500 \mu \mathrm{S} / \mathrm{cm}$. If the specific conductance of the sample is greater than 2,500 $\mu \mathrm{S} / \mathrm{cm}$ the sample must be diluted; however, detection levels and sensitivity will change proportionally.

10. Method/procedure detection level: At the time of this study, the long-term method detection level (LT-MDL) for vanadium was $0.05 \mu \mathrm{g} / \mathrm{L}$. The reporting level (RL) was $0.10 \mu \mathrm{g} / \mathrm{L}$.

\section{Zinc}

1. Parameter name: Zinc (zinc as Zn).

2. Sample fraction: Zinc analyses are performed on filtered water samples.

3. Measurement units: Zinc concentrations are reported in micrograms per liter $(\mu \mathrm{g} / \mathrm{L})$.

4. Field or lab measurement: Measurement of zinc concentrations was conducted at the USGS NWQL in Lakewood, Colorado. 
5. Value type: Actual.

6. Description of sample preparation procedure:

Sample water was syringe filtered through a disposable 0.45 -micron pore disk filter into a 250 -mL polyethylene, acidrinsed bottle. The bottle previously had been lab-rinsed with distilled water and transported to the field half filled with distilled water. In the field, the bottle was emptied and then rinsed once with filtered sample water. (At Superintendent's Spring, USGS Site ID 362856121103801 and Chalone Bridge Spring, USGS Site ID 362912121101101—disposable 0.45-micron pore capsule filters were used due to excess turbidity).

7. Description of sample transport/preservation: After collection, the sample was acidified with nitric acid $\left(\mathrm{HNO}_{3}\right)$ to a pH of less than 2 . The bottle was sealed in a plastic bag and packed into a cooler, without ice, for shipment to the NWQL.

8. Lab analytical method/procedure name, source citation, and ID: NWQL Method I-202005, Schedule 2710: Trace elements; Lab code 3138: Zinc, using collision/reaction cell inductively coupled plasma (ICP), mass spectrometry (MS) (Garbarino and others, 2006).

9. Maximum and minimum quantification limits for the method or procedure: The upper calibration limit for zinc analysis by the ICP-MS method is $1,000 \mu \mathrm{g} / \mathrm{L}$ for samples with specific conductance less than $2,500 \mu \mathrm{S} / \mathrm{cm}$. If the specific conductance of the sample is greater than $2,500 \mu \mathrm{S} / \mathrm{cm}$ the sample must be diluted; however, detection levels and sensitivity will change proportionally.

10. Method/procedure detection level: At the time of this study, the long-term method detection level (LT-MDL) for zinc was $0.3 \mu \mathrm{g} / \mathrm{L}$. The reporting level (RL) was $0.6 \mu \mathrm{g} / \mathrm{L}$.

\section{Deuterium/Protium Ratio}

1. Parameter name: Deuterium/protium ratio $\left({ }^{2} \mathrm{H} /{ }^{1} \mathrm{H}\right)$

2. Sample fraction: Deuterium/protium ratio analyses are performed on unfiltered water samples, except for two samples (listed in Item 6 below).

3. Measurement units: Deuterium/protium ratios are reported in per mil (indicates parts deuterium per thousand parts protium; ${ }^{2} \mathrm{H} /{ }^{1} \mathrm{H}$ ), relative to Vienna Standard Mean Ocean Water.

4. Field or lab measurement: Measurement of deuterium/protium ratios was conducted at the USGS Reston Stable Isotope Laboratory in Reston, Virginia.

5. Value type: Actual.

6. Description of sample preparation procedure: Unfiltered sample water was collected into a $60-\mathrm{mL}$ glass bottle with a polyseal cap. (At Superintendent's Spring-USGS Site ID 362856121103801 and Chalone Bridge Spring-USGS Site ID 362912121101101—disposable 0.45-micron pore capsule filters were used due to excess turbidity). Samples were allowed to overflow the bottle, and then part of the sample was discarded to provide headspace in the bottle. Bottles were not field rinsed.
7. Description of sample transport/preservation: The bottle was sealed in a plastic bag and packed into a cooler, without ice, for shipment to USGS Reston, Virginia, Isotope Lab.

8. Lab analytical method/procedure name, source citation, and ID: Lab Schedule 1142; Lab Code 1574: deuterium/protium ratio, using mass spectrometry (Revesz and Coplen, 2003a).

9. Maximum and minimum quantification limits for the method or procedure: Not applicable.

10. Method/procedure detection level: The 2-sigma uncertainty of hydrogen isotopic results is 2 per mil. This means that if the same sample were resubmitted for isotopic analysis, the newly measured value would lay within the uncertainty bounds 95 percent of the time.

\section{Oxygen-18/Oxygen-16 Ratio}

1. Parameter name: Oxygen-18/oxygen-16 ratio $\left({ }^{18} \mathrm{O} /{ }^{16} \mathrm{O}\right)$

2. Sample fraction: Oxygen-18/oxygen-16 ratio analyses are performed on unfiltered water samples, except for two samples (listed in Item 6 below).

3. Measurement units: Oxygen-18/oxygen-16 ratios are reported in per mil (indicates parts oxygen-18 per thousand parts oxygen-16; ${ }^{18} \mathrm{O} /{ }^{16} \mathrm{O}$ ), relative to Vienna Standard Mean Ocean Water.

4. Field or lab measurement: Measurement of oxygen18/oxygen-16 ratios was conducted at the USGS Reston Stable Isotope Laboratory in Reston, Virginia.

5. Value type: Actual.

6. Description of sample preparation procedure: Unfiltered sample water was collected into a $60-\mathrm{mL}$ glass bottle with a polyseal cap. (At Superintendent's Spring-USGS Site ID 362856121103801 and Chalone Bridge Spring-USGS Site ID 362912121101101—disposable 0.45-micron pore capsule filters were used due to excess turbidity). Samples were allowed to overflow the bottle, and then part of the sample was discarded to provide headspace in the bottle. Bottles were not field rinsed.

7. Description of sample transport/preservation: The bottle was sealed in a plastic bag and packed into a cooler, without ice, for shipment to USGS Reston, Virginia, Isotope Lab.

8. Lab analytical method/procedure name, source citation, and ID: Lab Schedule 1142; Lab Code 489: oxygen18/oxygen-16 ratio, using mass spectrometry (Revesz and Coplen, 2003b).

9. Maximum and minimum quantification limits for the method or procedure: Not applicable.

10. Method/procedure detection level: The 2-sigma uncertainty of oxygen isotopic results is 0.2 per mil. This means that if the same sample were resubmitted for isotopic analysis, the newly measured value would lay within the uncertainty bounds 95 percent of the time. 


\section{Tritium}

1. Parameter name: Tritium $\left({ }^{3} \mathrm{H}\right)$ (tritium in water molecules)

2. Sample fraction: Tritium analyses are performed on unfiltered water samples, except for at the two sample sites listed in Item 6 below.

3. Measurement units: Tritium is reported in picocuries per liter (pCi/L).

4. Field or lab measurement: Measurement of tritium concentrations was conducted at the University of Miami, Tritium Laboratory, Miami, Florida.

5. Value type: Actual.

6. Description of sample preparation procedure: Unfiltered sample water was collected into a $1 \mathrm{~L}$ polyethylene bottle with a Polyseal cap. (At Superintendent's Spring-USGS Site ID 362856121103801 and Chalone Bridge Spring-USGS Site ID 362912121101101—disposable 0.45-micron pore capsule filters were used due to excess turbidity). The bottle previously had been lab-rinsed with distilled water and transported to the field half filled with distilled water. In the field, the bottle was emptied and then rinsed once with unfiltered sample water. Samples were allowed to overflow the bottle, and part of the sample was discarded to provide headspace in the bottle.

7. Description of sample transport/preservation: The bottle was sealed in a plastic bag and packed into a cooler, without ice, for shipment to the University of Miami, Tritium Laboratory.

8. Lab analytical method/procedure name, source citation, and ID: Lab Code 1043: Tritium, by electrolytic enrichment and gas counting (Östlund, 1987).

9. Maximum and minimum quantification limits for the method or procedure: The limit of detection for tritium is $0.1 \mathrm{TU}$ (tritium units-1TU $=3.19 \mathrm{pCi} / \mathrm{L}$ ).

10. Method/procedure detection level: At the time of this study, the reporting level (RL) for tritium was $0.300 \mathrm{pCi} / \mathrm{L}$. 


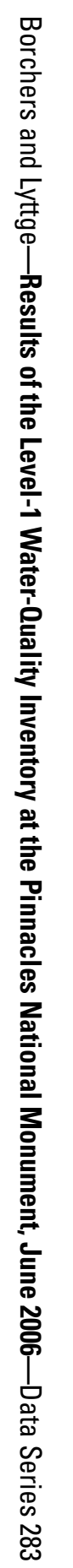

